Institute for
Fiscal Studies

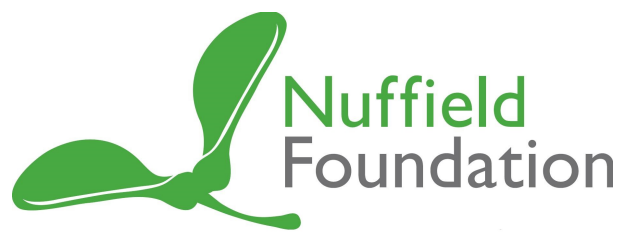

\title{
2018 Annual Report on Education Spending in England
}

Funded by the Nuffield Foundation

Chris Belfield

Christine Farquharson

Luke Sibieta 
2018 annual report on education spending in England

Chris Belfield

Christine Farquharson

Luke Sibieta

Copy-edited by Judith Payne

The Institute for Fiscal Studies 


\section{Published by}

\section{The Institute for Fiscal Studies}

7 Ridgmount Street

London WC1E 7AE

Tel: +44 (0) 20-7291 4800

Fax: +44 (0) 20-7323 4780

Email: mailbox@ifs.org.uk

Website: http://www.ifs.org.uk

(c) The Institute for Fiscal Studies, September 2018

ISBN 978-1-912805-10-5 


\section{Foreword from the Nuffield Foundation}

Public expenditure on education in the UK represents around $£ 90$ billion, or $4.3 \%$ of national income. Yet until last year, there was no comprehensive analysis of how that expenditure is targeted at different stages of education, how it has changed over time, the factors driving those changes, and the associated pressures and challenges.

That gap was filled by the 2017 IFS report - funded by the Nuffield Foundation - Long-run comparisons of spending per pupil across different stages of education. The influence of that report on policy debates convinced both the Foundation and IFS of the value of producing this type of analysis on a regular basis. All those working in the education system, as well as the wider public, stand to benefit from a clear and independent assessment of trends in education spending over time and from better understanding the balance of public and private financial contributions at different stages. Such data are essential considerations in decision-making, particularly in the context of continued pressure on public finances, economic uncertainty, and rising pupil and student numbers.

It is for these reasons that we have worked with IFS to instigate a series of three annual reports on education spending, of which this is the first. The report provides impartial analysis of spending across each stage of education, complementing the Foundation's goal to explore the impact on outcomes of educational participation across the system from the early years, through school, and into further and higher education and vocational training.

Each report will feature a more detailed focus on a particular stage of education, and this year that focus is on further education (including school sixth forms and adult education). The authors show that further education has been a big loser from education spending changes over the last 25 years. There have been significant cuts to spending per student since 2010, and further changes are on the horizon in terms of the regional devolution of responsibility for adult education, the tight timescale for the development of the new $T$ levels, and the continued focus on apprenticeships for adult learners.

The Nuffield Foundation has long been concerned about the particular challenges facing further education, and its relative neglect in both financial and policy terms. We are keen to improve the evidence base in this area and hope that this report will help to generate discussion, and ultimately interesting research proposals that we might consider funding.

We extend our thanks to the IFS team, in particular to Luke Sibieta, who has led the analysis, and to his co-authors Chris Belfield and Christine Farquharson. We hope the publication of this series of reports will become an important part of the education calendar.

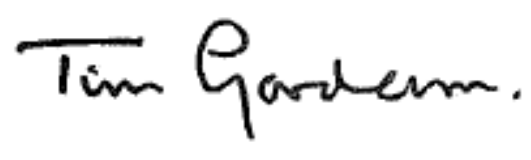

\section{Tim Gardam}

Chief Executive, Nuffield Foundation 


\section{Preface}

This report is the first in a series of annual reports on education spending in England. The authors gratefully acknowledge the support of the Nuffield Foundation (grant number EDO/43355), an endowed charitable trust that aims to improve social well-being in the widest sense. It funds research and innovation in education and social policy and also works to build capacity in education, science and social science research. The Nuffield Foundation has funded this project, but the views expressed are those of the authors and not necessarily those of the Foundation. More information is available at http://www.nuffieldfoundation.org. The authors also appreciate the Economic and Social Research Council, whose support through the Centre for the Microeconomic Analysis of Public Policy (grant number ES/M010147/1) at the Institute for Fiscal Studies underpins much of IFS's research.

The authors would like to thank the members of the advisory group, who have greatly informed the analysis in this report: Frank Bowley (Department for Education), Julian Gravatt (Association of Colleges), Claire Harding (Coram Family and Childcare), Sandra McNally (London School of Economics and Centre for Vocational Education Research), Polly Vizard (London School of Economics) and Anne West (London School of Economics). Comments from the Department for Education and colleagues at IFS are also gratefully acknowledged.

This report makes use of data releases from the Department for Education and other departments. It also uses data from the ONS Quarterly Labour Force Survey and the University of Essex's British Household Panel Survey.

The views and analysis presented in this report are those of the authors alone. Any errors or omissions are also their responsibility. 


\section{Contents}

Executive summary $\quad 6$

$\begin{array}{lr}\text { 1. Introduction } & 10\end{array}$

2. Early years 14

2.1 Description of the system 14

2.2 Spending levels $\quad 21$

2.3 Early years funding system 23

2.4 Other spending on the early years 26

$\begin{array}{lll}2.5 & \text { Summary and future challenges } & 27\end{array}$

3. Schools 28

3.1 Primary and secondary school spending per pupil 28

3.2 Wider measure of school spending 31

3.3 Implementation of the National Funding Formula 33

3.4 Summary 34

4. Further education and skills 36

4.1 Participation trends 38

4.2 Spending levels $\quad 45$

4.3 Role of funding systems $\quad 50$

$\begin{array}{lll}4.4 & \text { Future reforms and challenges } & 60\end{array}$

5. Higher education $\quad 62$

5.1 University resources $\quad 62$

5.2 Government finances

5.3 Graduate repayments 68

5.4 Potential upcoming reforms 70

$\begin{array}{lll}5.5 & \text { Future challenges } & 72\end{array}$

$\begin{array}{lr}\text { 6. Comparisons and conclusions } & 74\end{array}$

Appendix A. Early years spending data $\quad 77$

Appendix B. Further education and sixth forms: sources and methodology $\quad 79$

Appendix C. Higher education 182

$\begin{array}{ll}\text { References } & 83\end{array}$ 


\section{Executive summary}

Education spending is the second-largest element of public service spending in the UK behind health, representing about $£ 90$ billion in 2017-18 in today's prices or about $4.3 \%$ of national income. The level of UK education spending has risen significantly in real terms over time, growing particularly fast from the late 1990s through to the late 2000s, before falling in real terms from 2010 onwards. Whilst important, such overall trends in total education spending tell us little about what has happened to the different areas of education spending.

Our first annual report on education spending in England provides measures of spending per student in the early years, schools, further education and higher education back to the early 1990s. These series of day-to-day spending per pupil allow us to understand how policy decisions have affected the resources available to students in different stages of education over the long run.

\section{Key findings}

\section{Early years}

- Government spending on early years education was around $£ 3,200$ per 3 - or 4-yearold child in 2017-18. In the early 1990s, early years spending was less than $£ 100$ million in 2018-19 prices. By 2017-18, this had risen to $£ 3$ billion on 3- and 4-year-olds. This large increase was the result of the introduction, and subsequent extension, of the entitlement to free part-time pre-school education for this age group. Spending on the free entitlement for disadvantaged 2-year-olds was about $£ 500$ million.

- Large spending increases in the past year were driven both by offering more funded hours and by increasing the per-hour rate of funding. Spending on 3- and 4year-old early education rose by $22 \%$ in 2017-18. Much of this increase was the direct result of additional funded hours for working parents under the new 30-hour entitlement. The government also increased spending per hour by $9 \%$ in an effort to incentivise providers to offer the new extended entitlement.

- The new Early Years National Funding Formula offers a welcome step towards transparency and consistency in funding. However, it is difficult for the funding formula to incentivise and support high-quality provision as there is no agreed definition of 'high-quality' provision. A focus on minimising costs could also have unintended consequences by making it more difficult for childcare settings to provide high-quality care that supports children's development.

- Including Sure Start and childcare subsidies, total early years spending was about $\mathbf{£ 5 . 8}$ billion in 2017-18. Whilst spending on the free entitlement more than doubled in real terms between 2009-10 and 2017-18, spending on childcare subsidies fell by $13 \%$ and Sure Start spending by $67 \%$. As a result, spending on the free entitlement represented a much larger share of early years spending in 2017-18 (60\%) than in 2009$10(29 \%)$. 


\section{Schools}

- Total spending on schools in England represented just under $£ 42$ billion in 2017-18 (in 2018-19 prices). This represents $£ 4,700$ per pupil at primary school and $£ 6,200$ per pupil at secondary school. This excludes spending by local authorities on central services, as well as spending by special schools.

- Primary and secondary school spending per pupil rose by over $50 \%$ in real terms between 2000-01 and 2010-11, and was largely protected in real terms after 2010. The average level of spending per pupil by primary and secondary schools rose by around $5 \%$ per year in real terms during the 2000s and was then largely protected in real terms under the coalition government. Spending per pupil fell $4 \%$ in real terms between 2015-16 and 2017-18, but will be held constant in real terms up to 2019-20. This will still leave spending per pupil more than $60 \%$ higher in real terms than in 2000 01.

- Total school spending per pupil fell by $8 \%$ in real terms between 2009-10 and 201718 , and will only be about $14 \%$ higher in real terms in 2017-18 than in 2003-04. This adds on the additional effect of a 55\% real-terms cut in local authority service spending and a real-terms cut of more than $20 \%$ to school sixth-form spending per student between 2009-10 and 2017-18. Spending per pupil by individual schools was partly buttressed by transfers of responsibility and funding from local authorities to schools. This total measure is probably the most comprehensive measure of public spending on schools over time.

- Schools' costs increased more slowly than inflation between 2010-11 and 2015-16, but grew faster than inflation afterwards. Squeezes on public sector pay between 2010-11 and 2015-16 meant that public sector pay per head grew more slowly (6\%) than overall inflation (8\%). Between 2015-16 and 2019-20, additional employer costs and the ending of the $1 \%$ public sector pay cap mean that we expect public sector pay per head to grow faster (11\%) than inflation (7\%).

\section{Further education and skills}

- Participation in full-time 16-18 education has more than doubled since the 1980 s. The proportion of 16- and 17-year-olds in full-time education rose from $40 \%$ in the mid 1980 s to $82 \%$ in 2017 . As a result, the proportion in paid employment without training went down from $21 \%$ to $2 \%$ and the proportion in other forms of education or training fell from $29 \%$ to $12 \%$.

- Total spending on 16-18 education in England was just under $£ 5.8$ billion in 201718. Spending per student in further education and sixth-form colleges was about $£ 5,700$ in 2017-18, while that in school sixth forms was about $£ 5,000$. This lower level of spending per student in school sixth forms is a dramatic reversal: in the mid 2000s, spending per student was about $£ 600$ higher than in further education and sixth-form colleges.

- 16-18 education has been a big loser from education spending changes over the last 25 years. In 1990-91, spending per student in further education was 50\% higher than spending per student in secondary schools, but it is now about $8 \%$ lower. Spending on further education fell faster during the 1990s, grew more slowly in the 2000s, and has been one of the few areas of education spending to see cuts since 2010 . 
- Spending per student aged 16-18 has fallen faster in school sixth forms than in further education since $\mathbf{2 0 1 0}$. Spending per student in 16-18 further education fell by $8 \%$ in real terms between $2010-11$ and $2017-18$ and by over $20 \%$ in school sixth forms.

- Spending and numbers in 19+ further education have both fallen significantly over time. The total number of adult learners fell from 4 million in 2005 to about 2.2 million by 2016. Most of this decrease was driven by falls in the number of learners taking lowlevel qualifications (below GCSE). Total funding for adult education and apprenticeships fell by $45 \%$ in real terms between 2009-10 and 2017-18, but spending per learner has remained roughly constant in real terms at just over $£ 1,000$ per learner each year.

- 19+ further education is sharply focused on apprenticeships. 19+ apprenticeship spending now represents $36 \%$ of total adult education funding, as opposed to $13 \%$ in 2010. Apprenticeships make up nearly half of all Level 2 qualifications undertaken by adults, having made up less than $10 \%$ in 2005 . They also now make up about two-thirds of all Level 3 adult learners.

- The further education and skills system is increasingly focused on developing specific occupational skills. From 2020, providers will begin implementing T levels around 15 lines of learning, with additional funding to increase teaching hours. Both $T$ levels and apprenticeships are focused on developing specific occupational skills. This could leave individuals more vulnerable to negative economic shocks than if they had more general skills.

- There are a range of funding systems in place to support FE, which have very different underlying principles for different groups of learners. The funding for 16to 19-year-olds reimburses learning institutions based on government estimates of cost, while the advanced learner loan system for higher-level qualifications and older learners treats students as consumers of education. This comes to a head in the adult education budget, where some students are expected to cover part of the cost of their course without any of the protection against low earnings offered by other systems.

\section{Higher education}

- Universities receive $£ 28,200$ per student to fund the cost of teaching their degrees. This is almost $60 \%$ higher than the level in 1997-98, largely as a result of the tuition fee reforms in 2006 and 2012 which boosted the level of university resources by $28 \%$ and $19 \%$ respectively.

- The expected long-run taxpayer cost of providing HE is $£ 8.5$ billion per cohort. The combined effect of the reforms since 2011 has reduced this cost from $£ 9.3$ billion, a saving of around $£ 800$ million per cohort of students that enter university.

- The HE finance system only contributes $£ 800$ million per cohort of students towards the government deficit. Government accounting rules mean that only grant spending counts towards the deficit; money paid out in student loans is not counted. Reforms since 2011 have significantly reduced grant spending, leading to a $90 \%$ reduction in the deficit impact. Interest accrued on student loans counts as income in the deficit too, regardless of whether it is expected to be paid. This 'income' is set to grow substantially over the coming years. 
- Under the new system, the lowest-earning $40 \%$ of graduates pay $£ 3,000$ less on average in student loan repayments over their lifetime than if they had started university in 2011. This is due to the higher repayment threshold for students starting university after 2012 . Conversely, the highest-earning $20 \%$ of graduates are expected to pay more than $£ 40,000$ more. 


\section{Introduction}

Education spending is the second-largest element of public service spending in the UK behind health, representing about $£ 90$ billion in 2017-18 in today's prices or about $4.3 \%$ of national income. As Figure 1.1 shows, the level of UK education spending has also risen significantly in real terms over time. Growth was particularly fast from the late 1990s through to the late 2000 s, with real-terms growth averaging about $5 \%$ per year between 1998-99 and 2010-11. Education spending has since fallen in real terms as spending cuts began to take effect from 2010 onwards. Between 2010-11 and 2017-18, it fell by about $14 \%$ in real terms, taking it back to the same level it was in 2005-06 and a similar share of national income to that last seen through most of the 1990s.

Whilst important, such overall trends in total education spending tell us little about what has happened to the different areas of education spending. Furthermore, given that the figures for UK education spending in Figure 1.1 do not include the cost of issuing student loans from 2011-12 onwards, the series is inconsistent over time and is likely to overstate cuts to education spending since 2010-11.

Whilst less than cuts to other areas of public spending, cuts to public education spending mean that there are resource pressures across all areas of education spending in England. The early years sector has been tasked with delivering a large expansion in entitlement to free early education and childcare; schools have recently made their first real-terms cuts in over two decades, just as the national funding formula is being rolled out; the further education sector has had to make deeper cuts than any other area of education; and the higher education finance system has faced continual reform in recent years to manage large increases in participation.

Figure 1.1. UK education spending (2018-19 prices)

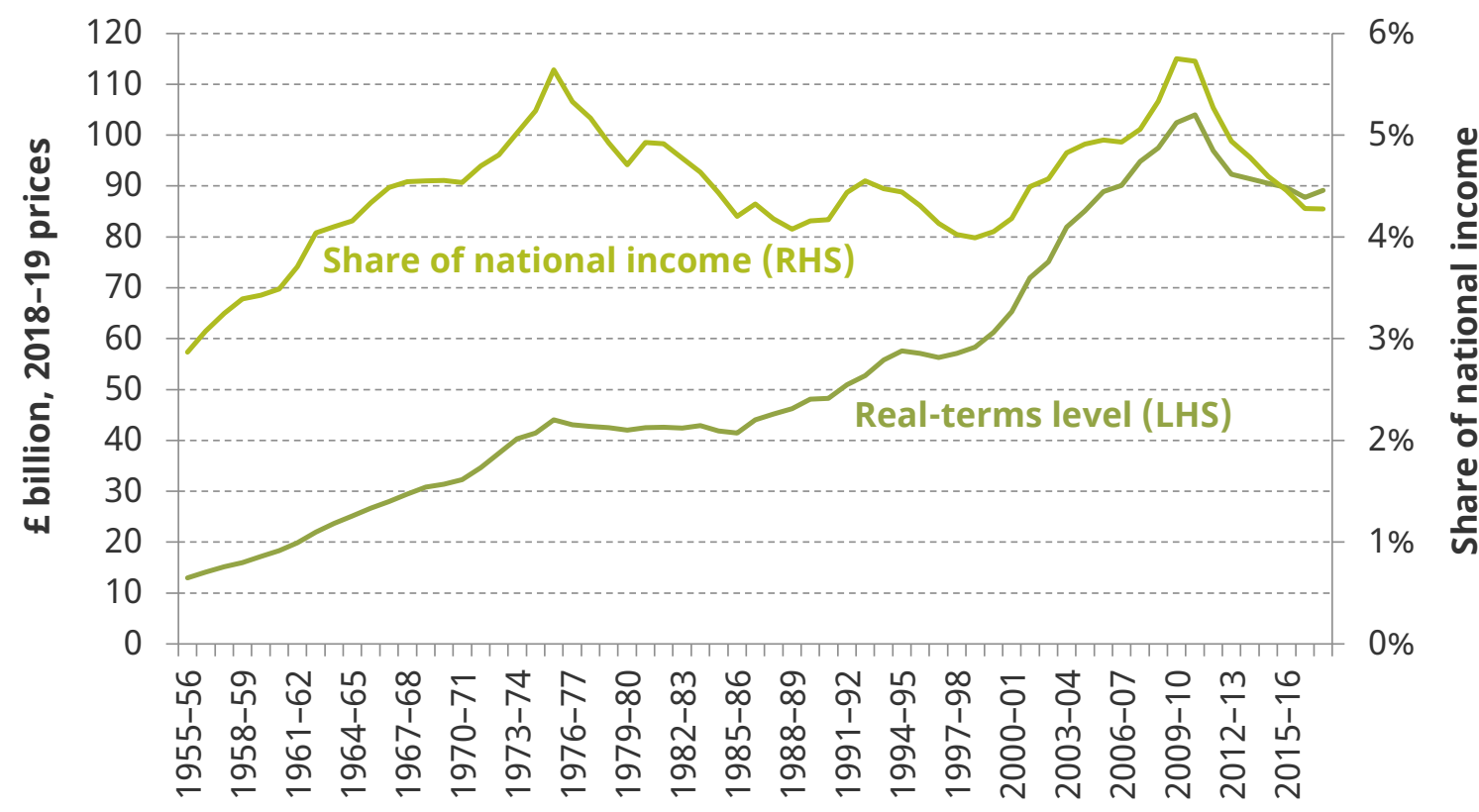

Source: HM Treasury, Public Expenditure Statistical Analyses 2018; previous PESAs; Office for National Statistics, Blue Book; HM Treasury deflators, March 2018 (https://www.gov.uk/government/statistics/gdp-deflators-atmarket-prices-and-money-gdp-march-2018-quarterly-national-accounts). 
To make efficient and equitable policy choices, it is crucial to have a clear, consistent picture of how much spending is targeted at each phase of education, how this has changed over time, how it is likely to evolve going forwards and what factors have driven these changes. This provides policymakers and the public with a sense of current resource priorities and future challenges. These issues are also a vital component of the education policy debate, particularly given the work by James Heckman and others emphasising the differential effectiveness of resources at different stages of the life course (Cunha, Heckman and Schennach, 2010).

Unfortunately, it has not always been possible to make such comparisons; until a recent report by IFS researchers (Belfield, Crawford and Sibieta, 2017) - supported by the Nuffield Foundation - there was no long-run and consistent picture of differences in spending per student across each phase of education.

In this first annual report on education spending in England, supported by the Nuffield Foundation, we update and improve our estimates of spending per student across each stage of education. In the case of higher education, we deliberately include the cost of issuing student loans, which is missing from headline measures of total education spending. We also detail the drivers of changes over time and the main resource challenges facing each sector in the near future. We will seek to continue to update these figures and analysis in future annual reports.

In each annual report, we will have a special focus on one stage of education. Given the historic squeeze on spending in further education identified in our previous report, we have chosen to focus on further education (ages 16-18 and 19+) and school sixth forms in this first report. We examine how the size and nature of each sector have changed over time, including the recent shift towards apprenticeships. We track total and per-student levels of spending over time. We detail how the funding systems operate and the implications of the incentives they create. Finally, we set out some of the main challenges facing the further education sector, which mainly revolve around the implementation of $T$ levels.

One crucial factor driving the total and per-pupil level of spending across different areas of spending is the total number of pupils over time. Figure 1.2(a) shows the number of pupils in state-funded primary and secondary schools over time. During the 1990s, the number of school-age pupils was on the rise, before then falling back over the course of the 2000s. Since 2010, it has risen again, with numbers in primary schools growing by $11 \%$ between 2010 and 2017, reaching their peak in about 2016. Numbers in secondary schools were relatively constant up to 2016, but are forecast to grow by $16 \%$ between 2016 and 2026.

Figure 1.2(b) then shows that there have been fast increases in the numbers of pupils in non-compulsory stages of education over time (early years, further education (16-18) and school sixth forms, and higher education). Given the scale of the changes in the number of pupils in state-funded schools in England, these increases mainly represent higher levels of participation at these stages rather than increases in cohort size. The number of children in pre-school education rose by around 70\% between 1999-2000 and 2017-18. The number of students in 16-18 education grew by over 70\% between 1990-91 and 201011 , from about 560,000 to 970,000 students (full-time equivalent, FTE). Since 2010-11, numbers have fallen by about $4 \%$, reflecting reduced cohort sizes rather than falls in 


\section{Figure 1.2. Pupil numbers in education in England}

\section{a) Schools}

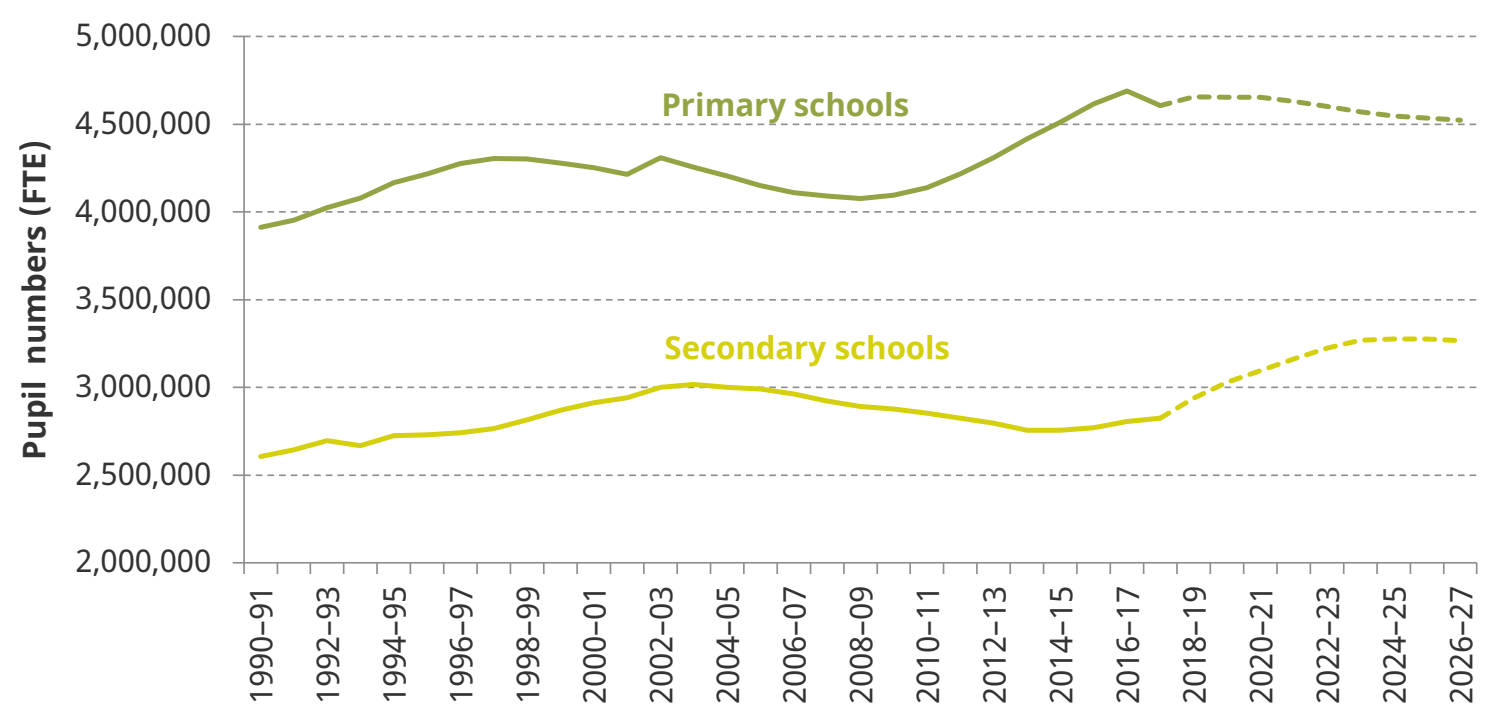

\section{b) Other stages of education}

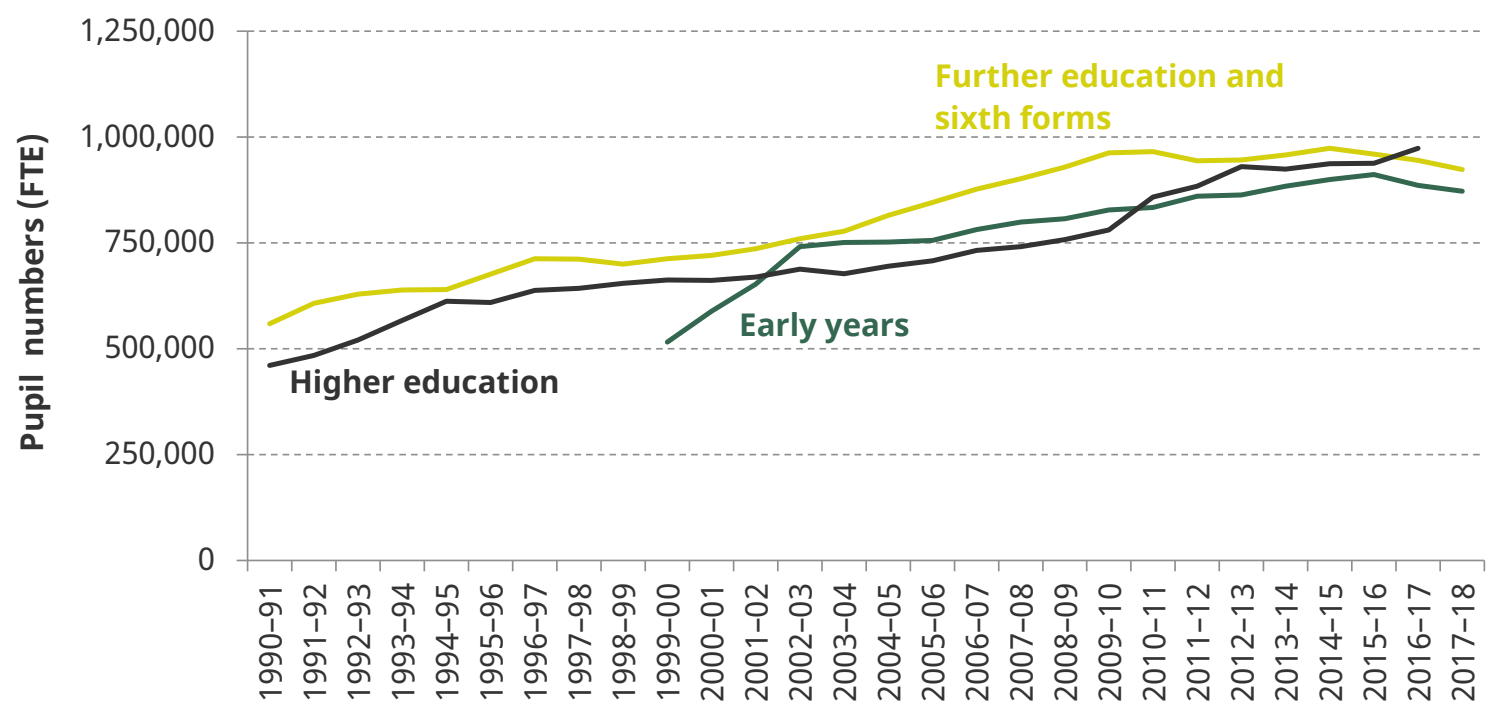

Source: Years refer to academic years. Early years taken from Department for Education, 'Education provision: children under five years of age', January 2018 (https://www.gov.uk/government/statistics/education-provisionchildren-under-5-years-of-age-january-2018), January 2010 (https://www.gov.uk/government/statistics/ provision-for-children-under-5-years-of-age-in-england-january-2010), January 2006

(http://webarchive.nationalarchives.gov.uk/20130329235614/http://www.education.gov.uk/researchandstatistics /statistics/statistics-by-topic/earlyyearsandchildcare/nurseries/a00195255/provision-for-children-under-fiveyears-of-age-in-) and January 2002 (http://webarchive.nationalarchives.gov.uk/20130323070608/ http://www.education.gov.uk/researchandstatistics/statistics/statistics-by-topic/earlyyearsandchildcare/ a00193904/provision-for-children-under-five-years-of-age-in-). Primary and secondary school numbers taken from Department for Education, 'Schools, pupils and their characteristics', January 2018 and earlier years (https://www.gov.uk/government/statistics/schools-pupils-and-their-characteristics-january-2018) and 'National pupil projections: July 2018' (https://www.gov.uk/government/statistics/national-pupil-projections-july-2018). Further education and sixth forms figures refer to 16- to 18-year-olds in state-funded schools or colleges as measured at the end of each calendar year in Department for Education, 'Participation in education, training and employment: 2017' (https://www.gov.uk/government/statistics/participation-in-education-training-andemployment-2017). Higher Education Statistics Authority figures (https://www.hesa.ac.uk/data-andanalysis/publications) and 'Historical statistics on the funding and development of the UK university system, 1920-2002' (https://discover.ukdataservice.ac.uk/catalogue/?sn=4971\&type=Data\%20catalogue). 
participation. Numbers in higher education have more than doubled since 1990 and continue to rise. As we shall see, this continuous increase in higher education student numbers has led many governments in recent years to make substantial changes to the higher education finance system in order to ensure sufficient levels of resources.

Throughout this report, we focus on current or day-to-day public spending on education in England. Capital spending is a much smaller share of education spending, relatively volatile and focused mostly on the school sector (Chowdry and Sibieta, 2011; Sibieta, 2015). We focus on England primarily for data availability reasons. We refer to spending per child in pre-school education for children aged 3 or 4, spending per pupil for children aged 5-16 and spending per student for young people aged over 16 . This follows standard naming conventions at each stage.

For the most part, we focus on public spending on education. This is due to a lack of reliable data on total private spending on each stage of education over time. The one exception to this is that we look in detail at how expected graduate contributions to the cost of higher education have increased over time. For schools, we also know that the proportion of pupils in independent schools has remained roughly steady at $6-7 \%$ since the early 1980s, despite average fees trebling in real terms between 1980 and 2016 (Green et al., 2017). In the early years, it's difficult to disentangle private spending on early education per se from more general spending on childcare, which has been recorded in a range of surveys (e.g. Harding and Cottell, 2018).

Our definition of spending is given in each chapter, with appendices and references to earlier reports given for further detail. In some cases, our measures of spending per pupil or student are calculated as total spending divided by the total number of pupils or students. In other cases, our calculations represent 'bottom-up' estimates of spending per pupil or student based on micro-data for schools and students in higher education.

The rest of this report is set out as follows: early years (Chapter 2); schools (Chapter 3); further education and skills (Chapter 4); higher education (Chapter 5); and comparisons and conclusions (Chapter 6). 


\section{Early years}

Over the past two decades, public spending and policy attention on the early years have risen significantly. This has been driven by two main policy objectives: improving child development and increasing maternal employment. Reflecting these two overarching aims, increases in public spending on the early years and childcare have taken many forms. ${ }^{1}$ First, governments have expanded demand-side subsidies, such as support for childcare through working tax credit or employer-sponsored (tax-free) childcare vouchers. Second, the government has provided some services directly (e.g. Sure Start Children's Centres). Third, the government provides supply-side subsidies through supporting free part-time pre-school education for 3- and 4-year-olds (as well as disadvantaged 2-yearolds). In this chapter, we concentrate on the last of these: the free entitlement to part-time pre-school education. This is because spending is focused on a well-defined age group and is closer to education, rather than childcare, spending.

In what follows, we start in Section 2.1 by describing how the free entitlement has changed over time, both in terms of the offer and in terms of levels of take-up. We include some early analysis of patterns of take-up and eligibility for the new 30-hour offer for working parents. Section 2.2 presents our main estimates of spend per child on the free entitlement and analysis of how this has changed over time. Section 2.3 describes how the new Early Years National Funding Formula works and some of the implications. Section 2.4 provides additional context by documenting trends in other related areas of early years spending. Section 2.5 concludes and describes key future challenges facing policymakers in this area.

\subsection{Description of the system}

\section{3- and 4-year-old entitlement}

The free entitlement offers a place in a registered childcare setting to all 3- and 4-year-old children in England. When it was initially introduced in 1997, the entitlement was restricted to part-time places during term time for 4-year-olds; now, the entitlement covers 15 hours per week for 38 weeks of the year, with an additional 15 hours weekly available to 3-and 4 -year-olds in most working households.

Table 2.1 shows how the national legal entitlement has changed over time, though it should be acknowledged that many local authorities had a more generous local offer as well (Brewer et al., 2016). For most of its history, the 3- and 4-year-old entitlement has been a universal policy, available to all children in the age group regardless of their family's means or their parents' work patterns. ${ }^{2}$ This universal approach mirrors the universal provision of education through schools, reflecting the role that early education can play in promoting children's social and intellectual development - although, in practice, evidence suggests that the benefits of the initial 3-year-olds offer for academic achievement have been small (Blanden et al., 2016).

1 For more details, see Stewart (2013), Brewer, Cattan and Crawford (2014), Stewart and Obolenskaya (2015) and West and Noden (2018).

2 The short-lived element of targeting for the $25 \%$ most disadvantaged in 2009 was part of a phased roll-out of the 15-hour offer, which was made available to all children the following year. 
Table 2.1. History of national free entitlement policies for 3- and 4-year-olds

\begin{tabular}{|c|c|c|c|c|}
\hline & Ages & $\begin{array}{c}\text { Hours per } \\
\text { week }\end{array}$ & $\begin{array}{c}\text { Weeks per } \\
\text { year }\end{array}$ & Targeting \\
\hline September 1997 & 4 & 12.5 & 33 & \\
\hline April 2004 & $3 \& 4$ & 12.5 & 33 & \\
\hline April 2006 & $3 \& 4$ & 12.5 & 38 & \\
\hline September 2009 & $3 \& 4$ & 12.5 or 15 & 38 & $\begin{array}{l}15 \text { hours for } 25 \% \text { most } \\
\text { disadvantaged }\end{array}$ \\
\hline September 2010 & $3 \& 4$ & 15 & 38 & \\
\hline September 2017 & $3 \& 4$ & 15 or 30 & 38 & $\begin{array}{l}30 \text { hours for children whose } \\
\text { parents work, earning } \\
\leq £ 100 \mathrm{~K} \text { each }\end{array}$ \\
\hline
\end{tabular}

Note: Adapted from West and Noden (2016).

More recently, the extension of the entitlement for children in households where all parents earn the equivalent of 16 hours of minimum-wage work ( $£ 125$ per week for parents aged 25 and older) suggests a change in approach for 3-and 4-year-olds. This targeting policy emphasises the importance of childcare in helping parents - particularly mothers - to work while they have young children at home. It is means-tested to some extent - families where one parent earns over $£ 100,000$ are not entitled - but given the small proportion of the population who are above this maximum threshold, the primary margin of targeting is on encouraging parents to work (or to work more hours).

Although an evaluation of the new policy has not yet been published, ${ }^{3}$ existing research suggests that offering subsidised childcare for 30 hours per week is significantly more effective in boosting employment than offering a part-time, 15-hour place: the offer of a term of full-time rather than part-time care increased the chances of a mother working by 1.2 percentage points (Brewer et al., 2016). However, these effects are limited to mothers whose youngest child is eligible for the subsidised childcare. ${ }^{4}$

\section{Take-up of the free and extended entitlements}

Local authorities are responsible for ensuring that there is enough childcare provision to meet the demand for free entitlement places. In practice, most of these places have been delivered by the private sector: around two-thirds of the free entitlement is currently delivered through private, voluntary and independent (PVI) settings rather than in schoolled settings. As Figure 2.1 shows, the PVI sector has been responsible for all the increased

3 The Department for Education is due to publish this evaluation in Autumn 2018. It has already published an evaluation of the early implementation of the extended entitlement, which found that $23 \%$ of mothers and $9 \%$ of fathers worked more hours after starting to use the extended entitlement hours (Paull et al., 2017). However, these figures should be interpreted with caution as they also capture changes that would have happened without the extended entitlement (e.g. parents working more hours as their children get older).

4 This research is based on eligibility for school, which also serves as a full-time, free childcare place available to everyone. By contrast, the current 30-hour offer is restricted to families where the parents are already in work. If parents need to have childcare in place before they are able to move into employment, the current policy would not have as large an impact as predicted by this research. 
free entitlement provision since 1999-2000, as the share of children in school-led provision has fallen from $45 \%$ to $34 \%$.

\section{Figure 2.1. Share of 3- and 4-year-olds taking up funded childcare, by sector}

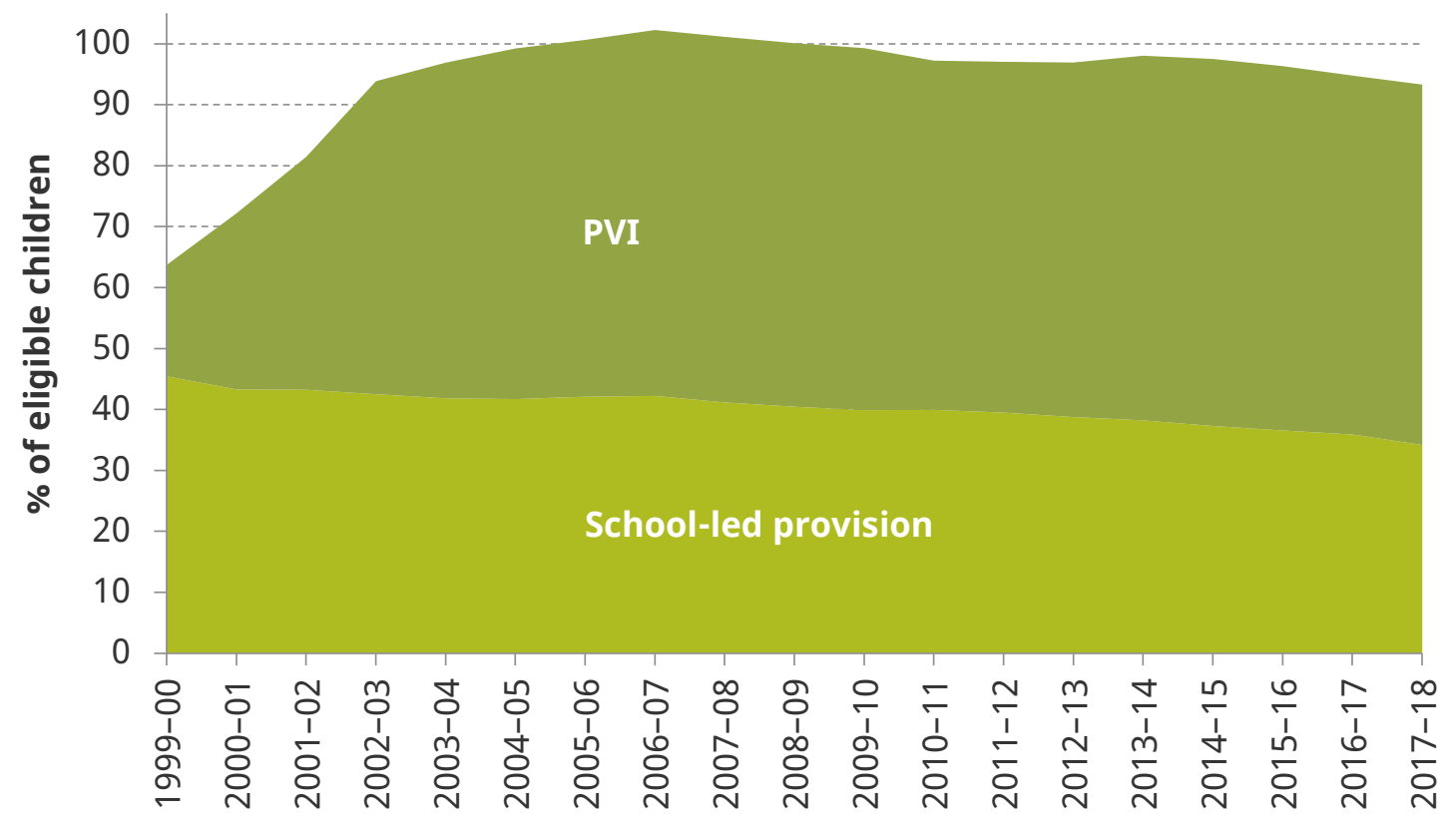

Note: PVI = private, voluntary and independent sector childcare providers. 'School-led provision' excludes places in infant classes or Reception Year. Take-up is calculated as a proportion of the population aged 3 or 4 who are age-eligible (not yet eligible for Reception) in January. Prior to 2010-11, the series double-counts children who are enrolled in multiple places, so take-up rates may be greater than $100 \%$. Prior to 2013-14, some 2-year-olds may be included in the figures.

Source: Department for Education, 'Education provision: children under five years of age', January 2017 (https://www.gov.uk/government/statistics/education-provision-children-under-5-years-of-age-january-2017), January 2010 (https://www.gov.uk/government/statistics/provision-for-children-under-5-years-of-age-inengland-january-2010), January 2009

(http://webarchive.nationalarchives.gov.uk/20130323070432/http://www.education.gov.uk/researchandstatistics /statistics/statistics-by-topic/earlyyearsandchildcare/a00196068/provision-for-children-under-five-years-of-agein-), January 2008

(http://webarchive.nationalarchives.gov.uk/20130323070441/http:/www.education.gov.uk/researchandstatistics/ statistics/statistics-by-topic/earlyyearsandchildcare/a00195777/provision-for-children-under-five-years-of-age), January 2007

(http://webarchive.nationalarchives.gov.uk/20130323070449/http://www.education.gov.uk/researchandstatistics /statistics/statistics-by-topic/earlyyearsandchildcare/a00195509/provision-for-children-under-five-years-of-agein-), January 2006

(http://webarchive.nationalarchives.gov.uk/20130323070456/http://www.education.gov.uk/researchandstatistics /statistics/statistics-by-topic/earlyyearsandchildcare/a00195255/provision-for-children-under-five-years-of-agein-) and January 2002

(http://webarchive.nationalarchives.gov.uk/20130323070608/http://www.education.gov.uk/researchandstatistics /statistics/statistics-by-topic/earlyyearsandchildcare/a00193904/provision-for-children-under-five-years-of-agein-). 
Figure 2.1 also makes clear that overall take-up rates have been very high for the last 15 years, with around $95 \%$ of 3 - and 4-year-olds using at least some of their free hours. ${ }^{5}$ This implies that the new extended entitlement could increase the number of free hours used in this age group, but there is not much scope left to move more children into using funded childcare services at all.

Data limitations mean that it is challenging to know precisely how many children are potentially eligible for the extended entitlement. The government estimates that around $390,000^{6}$ meet the criteria ( $42 \%$ of children eligible for the universal entitlement). ${ }^{7}$ Our

\section{Figure 2.2. Percentage of children eligible for the 30-hour extended entitlement}

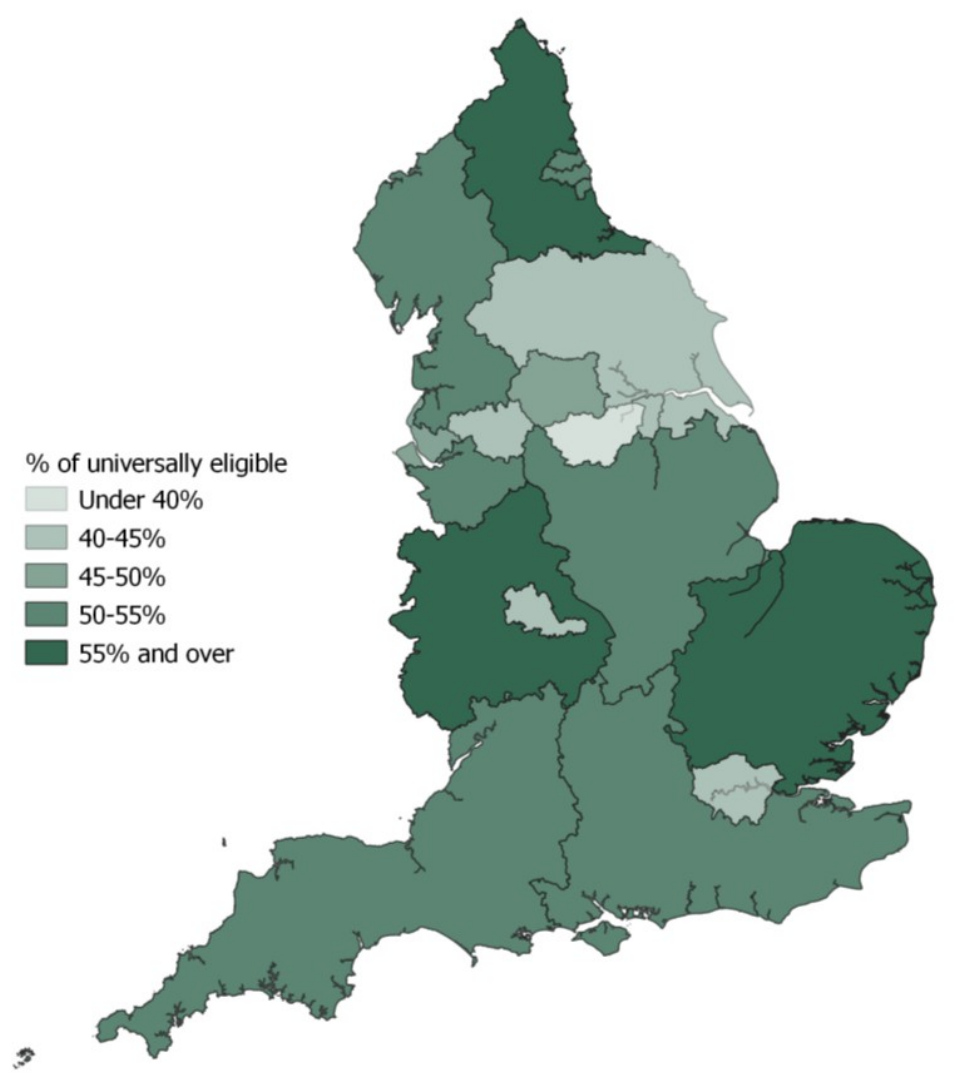

Note: The universally eligible population includes all children eligible for the universal 3- and 4-year-old entitlement (i.e. who turned 3 in the past term or before, and who are not yet eligible for Reception Year). The map shows the 15 regions available in the LFS data. Note that the 'Rest of North West' region includes counties both above and below Greater Manchester and Merseyside.

Source: Authors' calculations using the Labour Force Survey and ONS mid-year population estimates.

5 Perhaps surprisingly, take-up rates as a share of the population aged 3 and 4 rose little after the 3-year-old entitlement was introduced in 2004-05. As documented in Belfield, Crawford and Sibieta (2017), this is because many local authorities were already offering free places for some 3-year-olds prior to the official entitlement.

6 See the press release launching this policy: https://www.gov.uk/government/news/30-hours-free-childcarelaunches.

7 The number of children eligible for the universal entitlement changes over the year: a new group of 3-yearolds becomes eligible each term, but 4-year-olds age out of the entitlement (and into Reception Year) only once a year, in September. On average, there are around 930,000 children eligible for the universal entitlement. 


\section{Figure 2.3. Percentage of eligible children successfully applying for the extended entitlement}

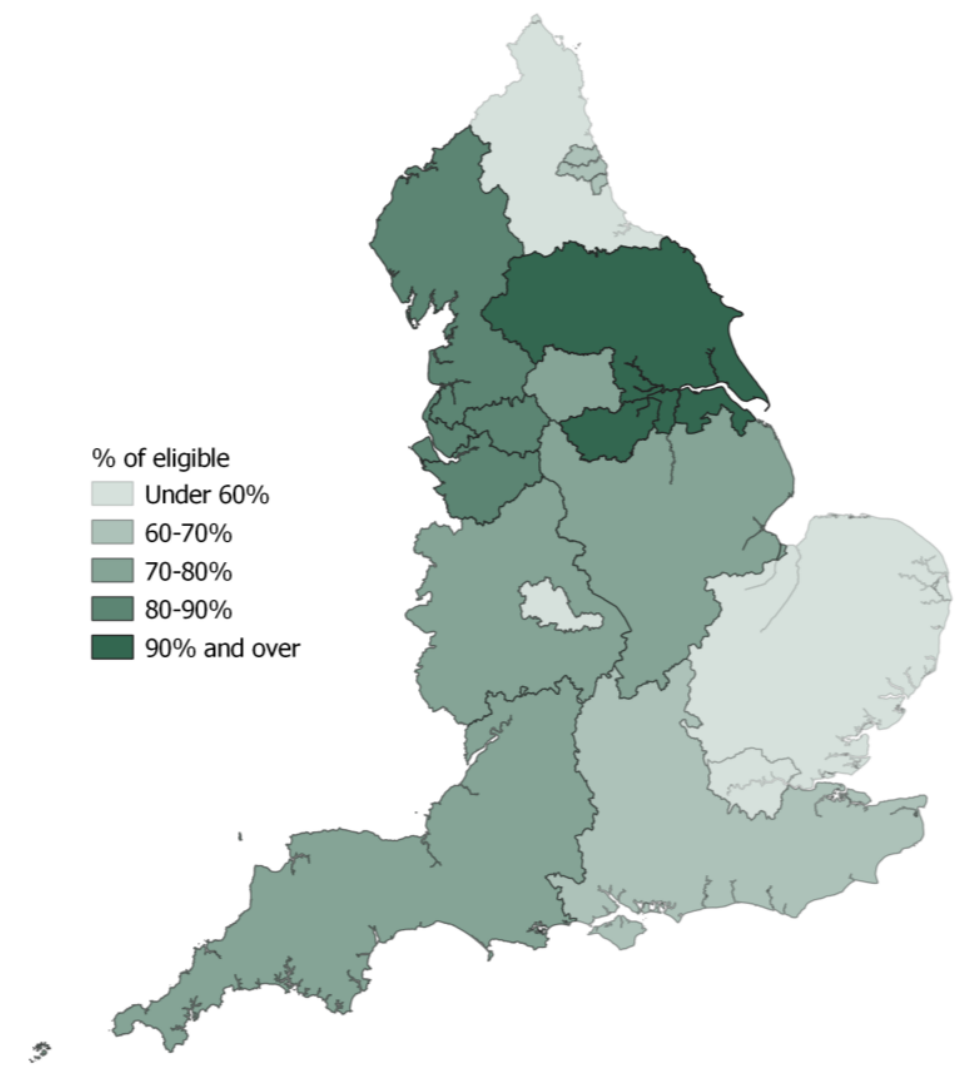

Note: The map shows the 15 regions available in the LFS data. Note that the 'Rest of North West' region includes counties both above and below Greater Manchester and Merseyside.

Source: Application rates from the Department for Education's statistical first release SFR16, averaged over Autumn 2017 and Spring and Summer 2018 terms. Eligibility rates from authors' calculations based on the Labour Force Survey and ONS mid-year population estimates.

estimates using the Labour Force Survey suggest that around 460,000 children are eligible, with the differences mainly due to the different data sets used.

Figure 2.2 illustrates how eligibility rates vary around the country. As a result of the low share of its parents in work, eligibility for the extended entitlement is lowest in South Yorkshire, where around a third of children live in families that meet the extended entitlement criteria. Eligibility is also relatively low in London and other urban areas such as the metropolitan West Midlands (which includes Birmingham) and Greater Manchester, though in these cases the low eligibility rates are driven by a greater proportion of singleearner couples.

In 2017-18, around 310,000 children - half of the eligible population - applied for an extended place. Unfortunately, it is impossible to know how many of the other eligible families faced barriers in accessing the programme, and how many simply preferred to use 15 hours of care or fewer each week. ${ }^{8}$ Figure 2.3 shows how successful application

8 Barriers to accessing the programme could include poor information, a challenging application process, or difficulties finding a place offering the extended entitlement. Surveys of providers suggest that some settings 
rates vary around the country. Over $90 \%$ of eligible children in South Yorkshire successfully applied for an extended entitlement place, while in other areas such as London only around half of eligible children successfully applied for an extended entitlement place. ${ }^{9}$

\section{Provision of the extended entitlement}

One of the most-discussed issues around the extended entitlement has been whether providers would be willing to offer the 30 -hour places. Without enough provision, eligible families would struggle to find a setting where they could use their 30 funded hours.

Unfortunately, evidence on whether this is actually a significant issue remains somewhat scarce. Two surveys conducted prior to the start of the extended entitlement had opposite conclusions (West and Noden, 2018). The Department for Education piloted the policy and found that, on the whole, providers in the pilot areas were willing to deliver the extended entitlement (Paull et al., 2017). The Pre-School Learning Alliance (2017) conducted an online survey of providers in March 2017. Many respondents had still not decided whether they would offer 30 -hour places, but of the 850 respondents who had made plans, around $70 \%$ intended to offer a place. However, around $60 \%$ of respondents also said that they expected the extended entitlement to have a negative impact on their business, with the level of funding a primary concern.

Crucially, though, both of these studies were carried out prior to the start of the extended entitlement - and prior to the new, higher, funding rates introduced in 2017-18. In addition, each focuses on a subset of providers. It is not clear how - or whether - these lessons generalise to the countrywide roll-out of the programme.

Evidence since the introduction of the extended entitlement is more limited. The Department for Education has released statistics on the number of children who have been approved for a place, which we can compare with the number of children taking up a place. Overall, around $90 \%$ of children who apply for and are eligible for extended entitlement funding end up taking up a place. The gap between application and take-up rates could indicate that some families are struggling to find suitable childcare places where they can use their extended entitlement. However, it could also be a result of families changing their minds about their childcare needs. ${ }^{10}$

It is also possible to look at the number of providers offering extended entitlement places. In January 2018 , there were 47,670 providers offering the universal, 15 -hour entitlement. At the same time, 34,250 providers $-72 \%$ of those delivering the universal entitlement offered extended entitlement places. State-funded primary schools were much less likely to offer the extended entitlement, while most day nurseries and childminders did offer 30-

are charging for extra items such as nappies and meals. While childcare providers are not able to make these extras a condition of taking up a place, if they have limited places available they can fill these first with families who are willing to pay for these items.

9 Parents apply for an extended entitlement place and, if they are eligible, are then issued a code to bring to their childcare provider. We use the Department for Education's data on codes issued - i.e. successful applicants.

10 This is particularly relevant for parents who are encouraged to apply for the 30 hours extended entitlement at the same time as for tax-free childcare, even if they plan to use their tax-free childcare at a provider that does not offer the extended entitlement. 
hour places. ${ }^{11}$ However, again it is not clear how much of an issue this is for the market: since fewer than half of the children who are eligible for the universal entitlement are also eligible for a 30-hour place, there do not need to be as many places on offer for the 30 hour entitlement as there are for the universal entitlement.

Of course, looking at national statistics can also hide areas where providers are struggling to deliver the extended entitlement; in a 2017 survey, half of local authorities felt they had enough childcare provision to deliver the extended entitlement, but the other half were not as confident (Harding and Cottell, 2018). And looking at whether a place is on offer does not tell us about any conditions attached to that place - for example, whether parents who are not willing to pay extra for items such as nappies and meals are squeezed out of places by families who are. As the extended entitlement policy develops, it is crucial that the Department for Education and the sector continue to monitor the state of the market to ensure that families who are entitled to a place and who want to use it are able to find one.

\section{2-year-old entitlement}

In September 2009, the government extended the free entitlement offer to some 2-yearolds. Unlike the entitlement for older children, the 2-year-olds offer has always been explicitly focused on providing early education to the most vulnerable children to promote their development. However, the definition of vulnerability used has expanded: from the $15 \%$ most disadvantaged in 2009 , to $20 \%$ in 2013 and $40 \%$ in $2014 .{ }^{12}$

Take-up among the 2-year-old entitlement children is much lower than among 3- and 4year-olds, with around $70 \%$ of eligible 2-year-olds taking up their free place (Department for Education, 2018b). To some extent, lower take-up rates in this age group should be expected: almost half of parents of 2-year-olds who do not use formal childcare say that this is because they prefer not to enrol their child in this type of care; only half as many families cite cost as the most important reason (Speight et al., 2015). In the short term, making care cheaper or free in this age group might be unlikely to change parents' preferences. $^{13}$

The 2-year-old entitlement has been delivered almost exclusively through PVI providers, who provide almost $90 \%$ of the places in this age group (Department for Education, 2018b). Since the free entitlement in this age range is particularly focused on providing high-quality early education to benefit the social and intellectual development of children from disadvantaged families, it will be especially important for the government to ensure that the education on offer in the 2-year-old settings is of high quality. However, some evidence suggests that this has traditionally been harder to achieve in PVI settings (Mathers and Smees, 2014; Blanden et al., 2016).

\footnotetext{
11 These figures relate to settings that offer at least one extended entitlement place, and so do not directly address the number of 30-hour places on offer. There may also be some inconsistency in how providers (particularly small settings such as childminders) who are willing to offer an extended entitlement but do not have a child eligible to take it up are recorded.

12 In practice, the 2-year-olds offer covers families who receive means-tested benefits such as income support or income-based jobseeker's allowance. Some children who are particularly vulnerable (e.g. those looked after by the local council or with special educational needs) are also eligible.

13 Recognising this, the government's target is for between $73 \%$ and $77 \%$ of eligible 2 -year-olds to take up some of their free entitlement (National Audit Office, 2016).
} 


\subsection{Spending levels}

Spending on the 3- and 4-year-old free entitlement has risen substantially since the turn of the century. Figure 2.4 shows the total amount of spending. To account for the growth in population over this period, it also shows spending per eligible child. ${ }^{14}$ These figures improve on those presented in Belfield, Crawford and Sibieta (2017) by using a more consistent measure of spending over time. ${ }^{15}$ Total spending per child rose from $£ 1,200$ in 2001-02 ( $£ 895$ per funded childcare place) to just under $£ 3,200$ in 2017-18. Much of this increase has come in the past year, with the roll-out of the 30 -hour extended entitlement.

Of course, the growth in total free entitlement spending since 2001-02 incorporates two separate underlying changes: increases in the generosity of the entitlement itself

Figure 2.4. Spending on the 3- and 4-year-old free entitlement: total and per child (2018-19 prices)

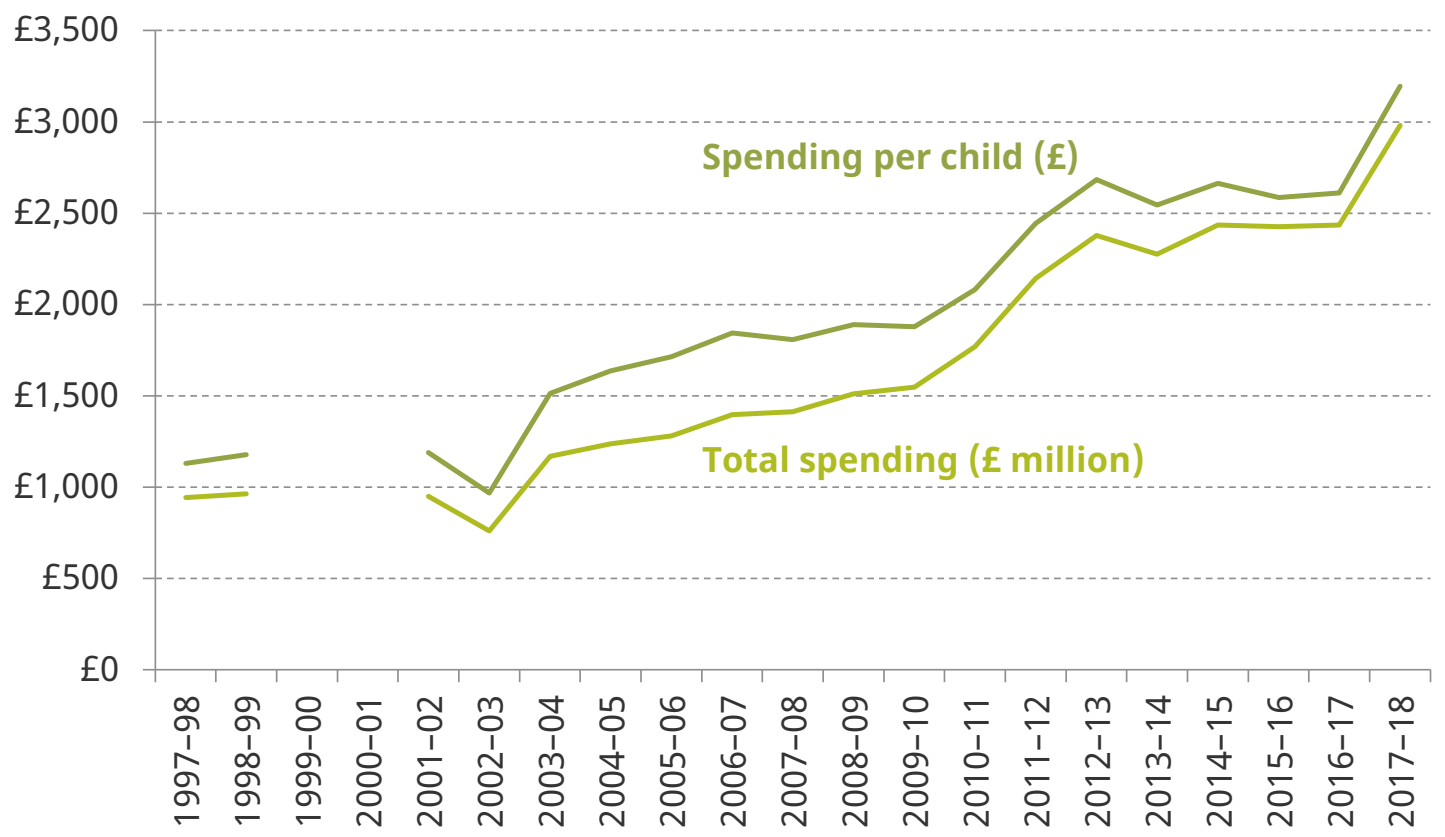

Note: Spending per child is calculated based on the average number of children eligible for the universal entitlement over the year. Spending figures in 2017-18 include spending on the 30-hour extended entitlement.

Source: Spending in 1997-98 and 1998-99 represents reported central government spending on nursery vouchers through the Nursery Education Grant listed in Department for Education and Employment (1999). Data for 1999-2000 to 2009-10 come from local authority out-turns. Data for 2010-11 onwards come from local authority budgets. For more detail, see Appendix A. HM Treasury deflators, March 2018

(https://www.gov.uk/government/statistics/gdp-deflators-at-market-prices-and-money-gdp-march-2018quarterly-national-accounts).

14 'Eligible' children are those who are eligible for the universal entitlement. Eligibility runs from the start of the term after a child's third birthday to the September after they turn 4, when they are eligible for Reception.

15 In Belfield, Crawford and Sibieta (2017), inconsistencies in the data reported over time meant that the spending series was imputed between 1999-2000 and 2011-12. Now we use a consistent data series between 1999-2000 and 2009-10, and another consistent series from 2010-11 onwards. These measures are still not perfect: up until 2009-10, our figures exclude spending on nursery classes (which are held in state primary schools). However, the series are more consistent over time and so provide a more accurate picture of trends in spending in the early years sector. Our data source for 1997-98 and 1998-99 is unchanged from the previous report. 
(primarily increasing the number of hours funded) and rises in the level at which government funds each hour of childcare delivered. Figure 2.5 disentangles the relative importance of each by comparing how different measures of spending have changed since the 3-year-old entitlement was introduced in 2004-05. The graph shows that:

- total real spending on the free entitlement in 2017-18 was just shy of two-and-a-half times as high as it was in 2004-05;

- spending per child was around twice as high in 2017-18 as in 2004-05. This slower growth reflects growth in the child population since 2004-05.

While population growth is an important determinant of government early years spending, most of the changes in the 3- and 4-year-old free entitlement over this period came not from bringing new children into funded childcare, but from extending the hours available to those using their free entitlement places. This is most obvious from the introduction of the extended entitlement: from 2016-17 to 2017-18, when the extended entitlement was introduced, total spending rose by the equivalent of $50 \%$ of the total budget in 2004-05.

Figure 2.5. Growth in real 3- and 4-year-old free entitlement spending

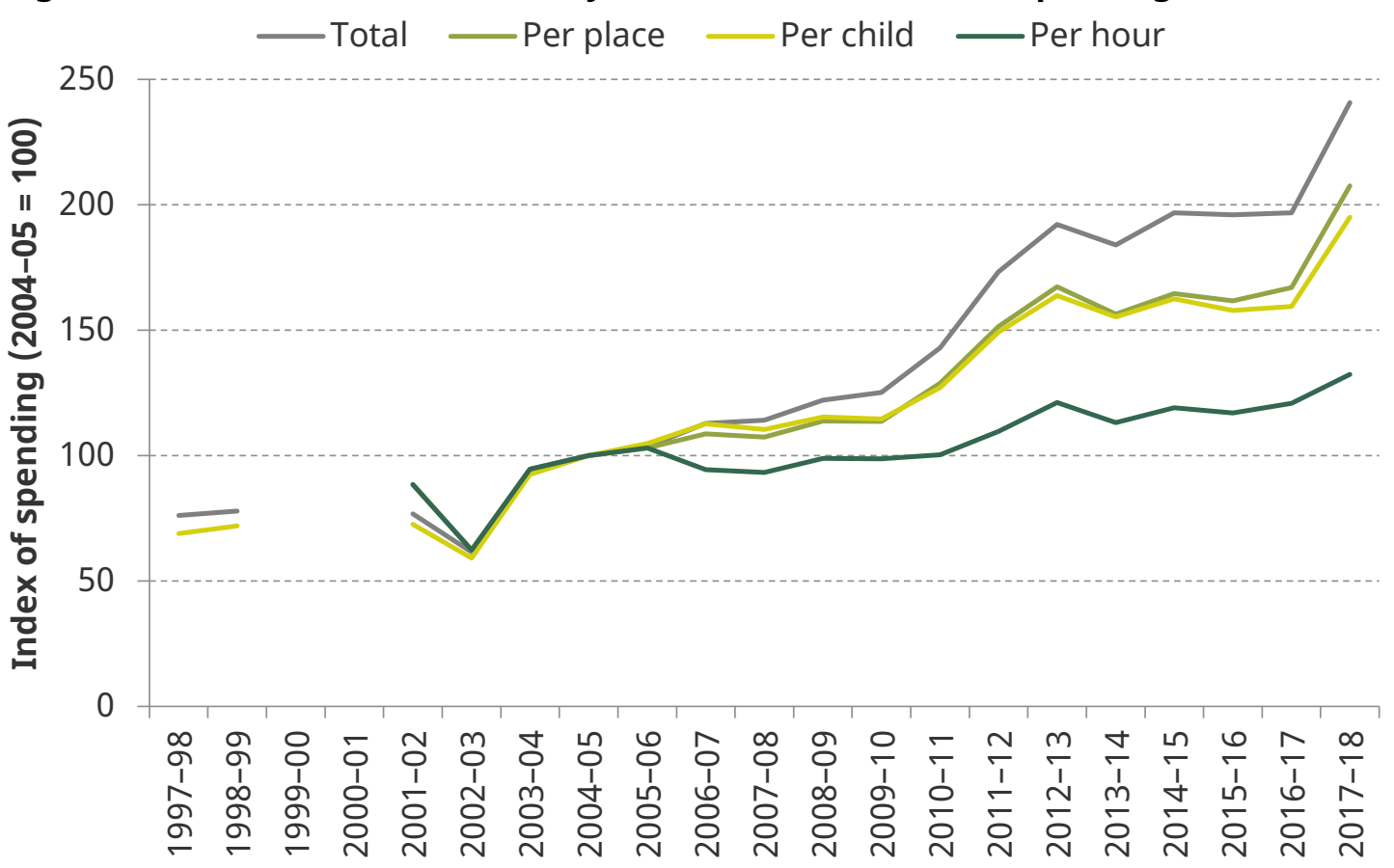

Note: Spending levels are indexed to 2004-05. Funding per place is based on the number of children taking up a universal free entitlement place. Funding per child is calculated based on the average number of children eligible for the universal entitlement over the year. Funding per hour assumes that all children taking up a place use the maximum number of funded hours available to them.

Source: Data for 1999-2000 to 2009-10 come from local authority out-turns. Data for 2010-11 onwards come from local authority budgets. For more detail, see Appendix A. HM Treasury deflators, March 2018 (https://www.gov.uk/government/statistics/gdp-deflators-at-market-prices-and-money-gdp-march-2018quarterly-national-accounts). 
To strip out the effects of these policy changes, Figure 2.5 therefore includes a measure of funding per hour, which assumes that all children using a free entitlement place take up the maximum number of hours available to them (including the extended entitlement, where applicable). ${ }^{16}$ Between 2003-04 and 2010-11, spending per hour was essentially flat. This was followed by two years of substantial spending increases - roughly $10 \%$ in each of 2011-12 and 2012-13 - and then a fall-back and recovery over the next four years.

In the most recent year, spending per hour rose by $11 \%$ of the $2004-05$ level. This reflects government commitments to increase the hourly funding rate for free entitlement to incentivise providers to offer the new extended entitlement and cover costs. While most of the big increase in total spending in the last year has been driven by the policy covering more children for more hours, this increase in the level of funding per hour is still significant, particularly in the context of several years of essentially flat or falling real funding levels.

\subsection{Early years funding system}

Funding from central government for the free entitlement is channelled through local authorities. Understanding the funding system therefore requires mapping out both how central government chooses to allocate money to different local authorities and how those local authorities then use the money to pay childcare providers.

Previously, central government allocated funding to local authorities each year based on the funding they had received in previous years, though until 2006 local authorities could choose to spend more (or less) than was centrally allocated. Just as in the schools funding system discussed in Belfield, Crawford and Sibieta (2017), this reliance on historical data led to funding allocations that treated local authorities with very similar characteristics quite differently.

\section{Early Years National Funding Formula}

In 2017-18, the Department for Education introduced the Early Years National Funding Formula (EYNFF) as a tool for allocating funding for the 3- and 4-year-old free entitlement. ${ }^{17}$ Under the EYNFF, the government allocates money to local authorities by calculating an hourly rate for each area. These hourly rates are based on a universal base rate - which was fixed across the country at $£ 3.53$ in 2017-18 - supplemented with uplifts for the level of disadvantage in the area. The disadvantage uplifts provide additional funding based on the share of children eligible for free school meals (who attract an extra $£ 2.13$ per hour), receiving disability living allowance ( $£ 0.74$ ) or recorded as having English as an additional language (£0.29)..$^{18}$ This is then uplifted by an area cost allowance, which captures the costs of labour and childcare premises in different areas of the country.

\footnotetext{
16 Although this is a reasonably good approximation for the 15-hour universal entitlement - current figures on take-up report that $96 \%$ of 3-year-olds and $82 \%$ of 4 -year-olds use between 13 and 15 hours of their entitlement - assuming full take-up of hours will understate spending per hour somewhat. However, since more precise figures on hours used are only available from $2007-08$, this is a necessary assumption to get a consistent series over time.

17 Further documentation is available at https://www.gov.uk/government/publications/early-years-nationalfunding-formula-allocations-and-guidance.

18 Since FSM and EAL data are not available for this age group, these rates are proxied by the share of primary pupils.
} 
When it introduced the EYNFF, the Department for Education also committed to a minimum funding level of $£ 4.30$ per hour as well as a cap on losses from the formula: no local authority would receive more than a $10 \%$ cash-terms cut relative to its previous funding rate. Further, the EYNFF also came with a three-year transition period, with local authorities transitioning to a lower funding rate losing no more than $5 \%$ of the previous year's budget in each of 2017-18 and 2018-19, with any remaining cut to reach the $10 \%$ loss cap amounting to under $0.3 \%$ in 2019-20 in cash terms. Local authorities that received - sometimes substantial - cash-terms increases also had these phased in during the transition period.

In calculating the funding rates used to allocate money between local authorities, central government does not consider characteristics of the providers in each area (beyond the general costs of labour and childcare premises). In particular, these central government rates do not attempt to distinguish between higher- and lower-quality providers. This reflects the significant challenges faced by government in identifying 'high-quality' provision, which are discussed later in this section. However, the challenges in measuring quality do not make it any less important.

Although the EYNFF does not consider the provider mix, until 2019-20 the funding system will provide supplementary funding through the Maintained Nursery Supplement to local authorities with a larger number of nursery schools (which are costlier than other settings, mainly due to the requirement that they employ qualified teachers). However, it is not clear what protections - if any - will be available thereafter.

\section{Local funding rules}

The EYNFF governs how central government allocates funding for the free entitlement to local authorities. However, it is local authorities which ultimately fund childcare providers. In the early years of the free entitlement, local authorities had quite a bit of discretion in funding childcare settings in their area, both in terms of the total amount of spending and in terms of how it was allocated (see West and Noden (2018) for a more detailed discussion). The introduction of a new Early Years Single Funding Formula in 2011 required local authorities to develop their own formulas to allocate early years spending to providers. ${ }^{19}$

Recent reforms to the system have increased central government's control over this process even further. The EYNFF introduced a new requirement that councils spend at least $95 \%$ of the early years funding they receive paying settings to deliver the free entitlement, leaving up to $5 \%$ of the budget for central services or other areas of education. The EYNFF also requires councils to adopt a universal funding rate for all providers by 2019-20 (though they will continue to be able to pay lump-sum top-ups to maintained nursery schools).

Councils can then build in funding supplements worth up to $10 \%$ of the amount they pay to providers. They must have a deprivation supplement and can also offer supplements for providers in rural areas, settings offering flexible hours or with more highly qualified staff or leadership, and settings with many children with English as an additional language.

19 For further details about the history of the Early Years Single Funding Formula that each council was required to develop, see West and Noden (2016). 
A universal funding rate for each provider type promotes efficiency in the delivery of funded childcare places: the highest-cost providers will be the most likely to leave the marketplace, leaving behind the more efficient settings. On the other hand, if higher-cost provision also tends to be of higher quality, a relentless focus on minimising costs could be detrimental for children's development.

\section{Promoting quality and minimising costs}

Ultimately, the funding formula for the early years must balance several competing objectives: promoting high-quality early education; ensuring sufficient and flexible provision, not least to deliver the new extended entitlement; and keeping the programme as a whole affordable for the public purse. In a standard marketplace, each family would make its own choice on how to balance quality, flexibility and cost. However, in the free entitlement system, parents face similar costs at every free entitlement setting, with families paying nothing for the funded hours themselves. ${ }^{20}$ It is therefore left to central government to constrain costs, while keeping funding high enough that settings are still willing to provide childcare under the free entitlement.

The notable increases in total and hourly funding for the free entitlement over the last year suggest that central government's attention has shifted away from the objective of minimising the cost to taxpayers, at least for the moment. Of course, different childcare settings face different costs of providing care, and so an increase in the average level of funding may still leave some settings underfunded relative to their costs. The challenge for government is to identify which of these differences in cost can and should be closed for example, some providers are more efficient than others - and which reflect settings' investment in providing high-quality childcare.

In a typical market, different levels of quality at different providers would be 'priced in' by consumers who are willing to pay more to receive a better service. But in the market for early education and childcare, it is particularly difficult both for government and for parents to know what a 'high-quality' setting looks like. For several years, quality has been measured by the inputs a setting provides: for example, the number of graduates on its staff. But recent research paints a more contested picture of whether these 'input quality' measures still provide a good indicator of what matters for children's outcomes. ${ }^{21}$ Most researchers agree that measures of 'process quality' - for example, how staff interact with children in their care - are more direct indicators of the quality of a childcare setting.

Unfortunately, process quality is so far very difficult to measure on a large scale, and therefore very difficult for government to take into account in the funding levels it sets. Given the importance of early education in helping to prevent and combat inequalities that develop early in life, and the recent extensions to the free entitlement, there is a substantial need for researchers and government to collaborate to understand how best

20 As discussed in greater detail in the earlier section on provision of the 30-hour entitlement, families might have to pay for 'extra' services such as meals or nappies in order to access some extended entitlement places.

21 The influential Effective Provision of Pre-School Education (EPPE) study from the late 1990s finds that settings that employ more qualified staff - particularly managers - tend to have higher process quality as well (Sylva et al., 2010). This association was also found in settings serving younger children by the Millennium Cohort Study (Mathers, Sylva and Joshi, 2007) and in evaluations of the Neighbourhood Nurseries Initiative (Neighbourhood Nurseries Initiative Research Team, 2007) and the Graduate Leader Fund (Mathers et al., 2011). However, recent work by Blanden, Hansen and McNally (2017) finds that the presence of a graduate in early years settings has only a very weak association with children's early school outcomes. 
to measure quality and how this can be incorporated into commissioning, procurement and funding frameworks.

\subsection{Other spending on the early years}

As mentioned at the start of this chapter, spending on the early years entitlement is not the only area of government support for the early years. The government also provides subsidies towards the cost of childcare through both the tax system (tax-free employerprovided vouchers and the new Tax-Free Childcare scheme) and the benefit system (childcare element of working tax credit). It also directly funds Sure Start Children's Centres. How have these other components of early years spending changed over time?

In a recent report for the Children's Commissioner in England (Kelly et al., 2018), we analysed how these components of spending have changed over time. Figure 2.6 shows how the total levels of spending on each component have changed over time.

Demand-side subsidies grew from about $£ 350$ million in 2001-02 to about $£ 2.0$ billion by 2009-10 ( $£ 1.6$ billion on the childcare element of working tax credit and $£ 400$ million on childcare vouchers, all in 2018-19 prices). Current spending on Sure Start Children's Centres grew from about $£ 600$ million in 2001-02 to reach about $£ 1.8$ billion in 2009-10 (all 2018-19 prices).

\section{Figure 2.6. Total early years spending through various sources, 2000-01 to 2017-18 (2018-19 prices)}

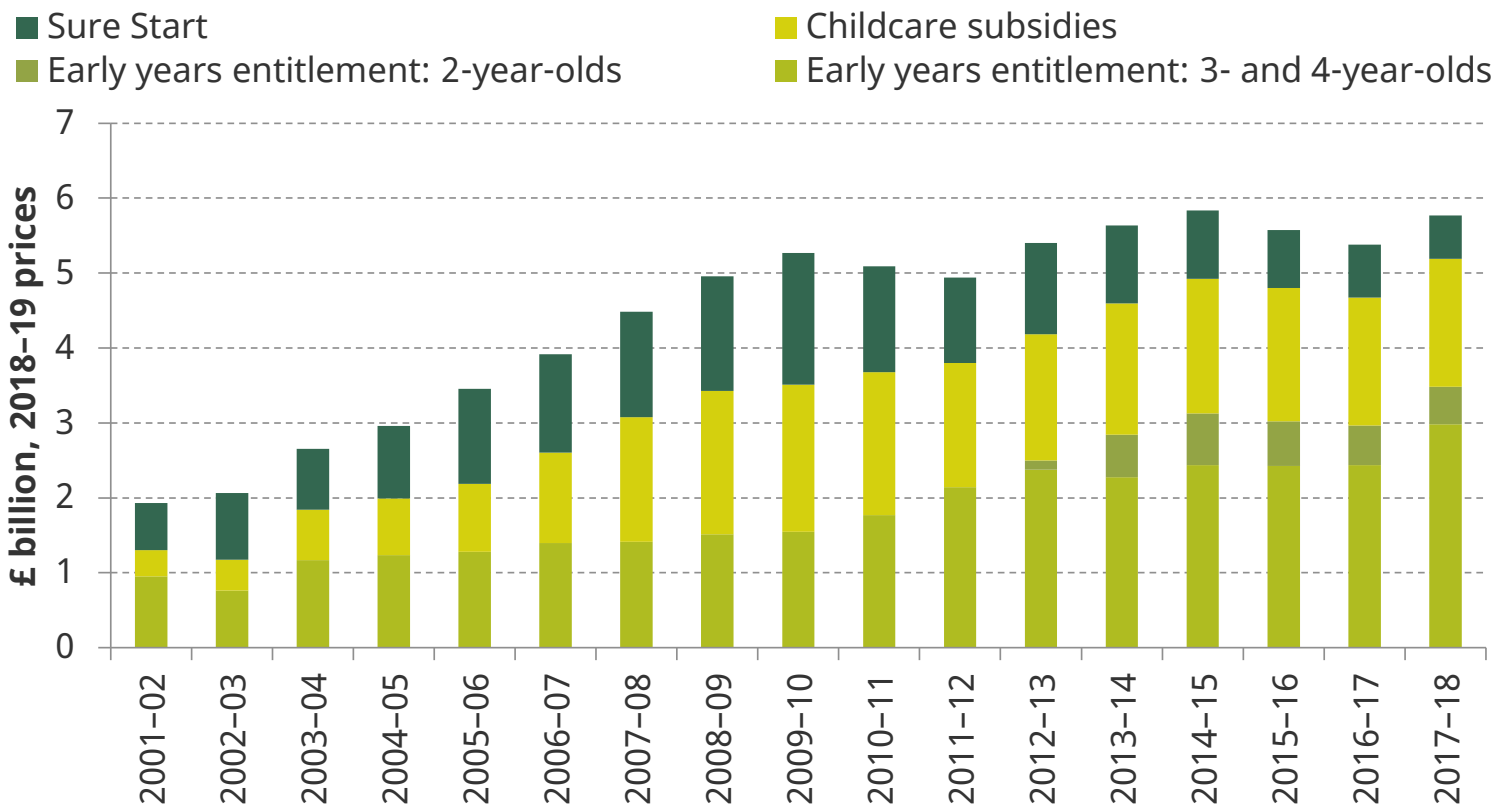

Source: See Figure 2.4 for details of sources for early years entitlement spending. See Kelly et al. (2018) for sources for childcare subsidies and Sure Start spending. HM Treasury deflators, March 2018 (https://www.gov.uk/government/statistics/gdp-deflators-at-market-prices-and-money-gdp-march-2018quarterly-national-accounts). 
Between 2009-10 and 2017-18, spending on demand-side subsidies has fallen by about $13 \%$ in real terms..$^{22}$ Most of this fall was driven by cuts to the childcare element of working tax credit as entitlements have become less generous; spending on this fell by $40 \%$ in real terms between 2009-10 and 2017-18. Estimated spending on employer childcare vouchers has doubled in real terms (from around $£ 400$ million in 2009-10 to $£ 800$ million in 201718). In very sharp contrast, day-to-day spending on Sure Start Children's Centres has fallen by around two-thirds in real terms between 2009-10 and 2017-18.

Adding all elements of early years spending together, this means that spending on the early years went from just over £1.9 billion (2018-19 prices) in 2001-02 (when half comprised subsidies to early years providers) up to around $£ 5.3$ billion in 2009-10 (comprising a combination of demand-side subsidies, supply-side subsidies and direct provision) and then up to about $£ 5.8$ billion by 2017-18. The overall increase since 2009-10 reflects additional spending on the free entitlement more than offsetting the cuts to demand-side subsidies and Sure Start. As a result, the free entitlement now makes up about $60 \%$ of total early years spending, as opposed to $29 \%$ in $2009-10$.

Looking forwards, the government is now phasing out employer-provided childcare vouchers and replacing them with a new, more generous system of Tax-Free Childcare. However, problems in accessing the new system of support led the Office for Budget Responsibility to significantly reduce its estimates of take-up in its November 2017 forecasts (decreasing estimated spending by about $£ 500$ million in 2018-19 and $£ 300$ million in 2019-20).

\subsection{Summary and future challenges}

Total spending on the early years has risen significantly over the last 30 years, from only about $£ 100$ million in the early $1990 \mathrm{~s}^{23}$ to about $£ 5.8$ billion in $2017-18$. Much of this now represents spending on the free entitlement to part-time early years education and childcare, which amounted to $£ 3.5$ billion in 2017-18. Increases in spending on the free entitlement over time have mainly reflected extensions in hours offered, with the latest extension in 2017-18 increasing the offer to 30 hours for most working parents.

There are two main related challenges for early years funding over the next few years. First, successful implementation of the new 30 hours extended entitlement will require providers to be willing to offer it, given the funding available. To date, many have, but there is significant geographical variation in take-up rates. The government should therefore continue to monitor overall levels and variation in take-up of the new extended entitlement. Second, it is not clear how and whether the new Early Years National Funding Formula can be used to promote high-quality provision. Whilst the new funding system is welcome in ensuring transparency and consistency in funding allocations, it is currently difficult for the funding formula to incentivise and support high-quality provision as there is no agreed definition of 'high-quality' provision. A focus on minimising costs could have unintended consequences by making it more difficult for childcare settings to provide high-quality care that supports children's development.

\footnotetext{
22 Assumes a real-terms freeze in both components in 2017-18.

23 See appendix A in Belfield, Crawford and Sibieta (2017).
} 


\section{Schools}

School spending covers pupils aged 5-16 and has been relatively protected in recent years. In 2017-18, total spending on schools in England represented about $£ 42$ billion (in 2018-19 prices), accounting for $14.4 \%$ of total public service spending in England. ${ }^{24}$

In what follows, Section 3.1 updates our estimates for primary and secondary school spending per pupil over time. Section 3.2 analyses how a more comprehensive measure of school spending - incorporating local authority spending and school sixth-form allocations - changes these trends over time. In Section 3.3, we set out the challenges for schools as a new national funding formula is implemented over the next few years. Section 3.4 summarises and concludes.

\subsection{Primary and secondary school spending per pupil}

Figure 3.1 shows our estimates for the level of primary and secondary school spending per pupil in England over time (in 2018-19 prices), together with projections for the level of spending per pupil implied by current policy announcements up to 2019-20. Here, our definition of school spending is the sum of the amount of spending undertaken by individual schools. This excludes spending undertaken directly by local authorities, spending on special schools and spending in independent fee-charging schools. For more details on the measure of school spending, see Belfield and Sibieta $(2016, \mathrm{ch}$. 3). In the next section, we discuss how trends change once we account for spending by local authorities and school sixth-form allocations.

As can be seen, spending per pupil has evolved in a number of distinct phases:

- Modest growth over the 1980s and 1990s: During the 1980s and 1990s, primary school spending per pupil grew by $2.3 \%$ per year, on average, in real terms and secondary school spending per pupil grew by slightly less (around 1.5\% per year, on average). There was also a fall of $6 \%$ in real terms in secondary school spending per pupil between 1993-94 and 1995-96.

- Rapid growth over the 2000s: From 1999 onwards, spending per pupil grew rapidly, with growth of around $5 \%$ per year in real terms for primary and secondary schools over the 2000s. This led primary school spending per pupil to rise from $£ 2,700$ per pupil in $1999-2000$ to reach $£ 4,500$ by $2009-10$, whilst secondary school spending per pupil grew from $£ 3,500$ to $£ 5,800$ per pupil.

24 Level of Dedicated Schools Grant in 2017-18 minus the early years element

(https://www.gov.uk/government/publications/dedicated-schools-grant-dsg-2017-to-2018) plus the Pupil Premium (https://www.gov.uk/government/publications/pupil-premium-conditions-of-grant-2017-to-2018) as a proportion of total resource departmental expenditure limits for 2017-18 (excluding Wales, Scotland and Northern Ireland) as recorded in PESA 2018 (https://www.gov.uk/government/statistics/public-expenditurestatistical-analyses-2018). 


\section{Figure 3.1. Spending per pupil in primary and secondary schools, actual and plans (2018-19 prices)}

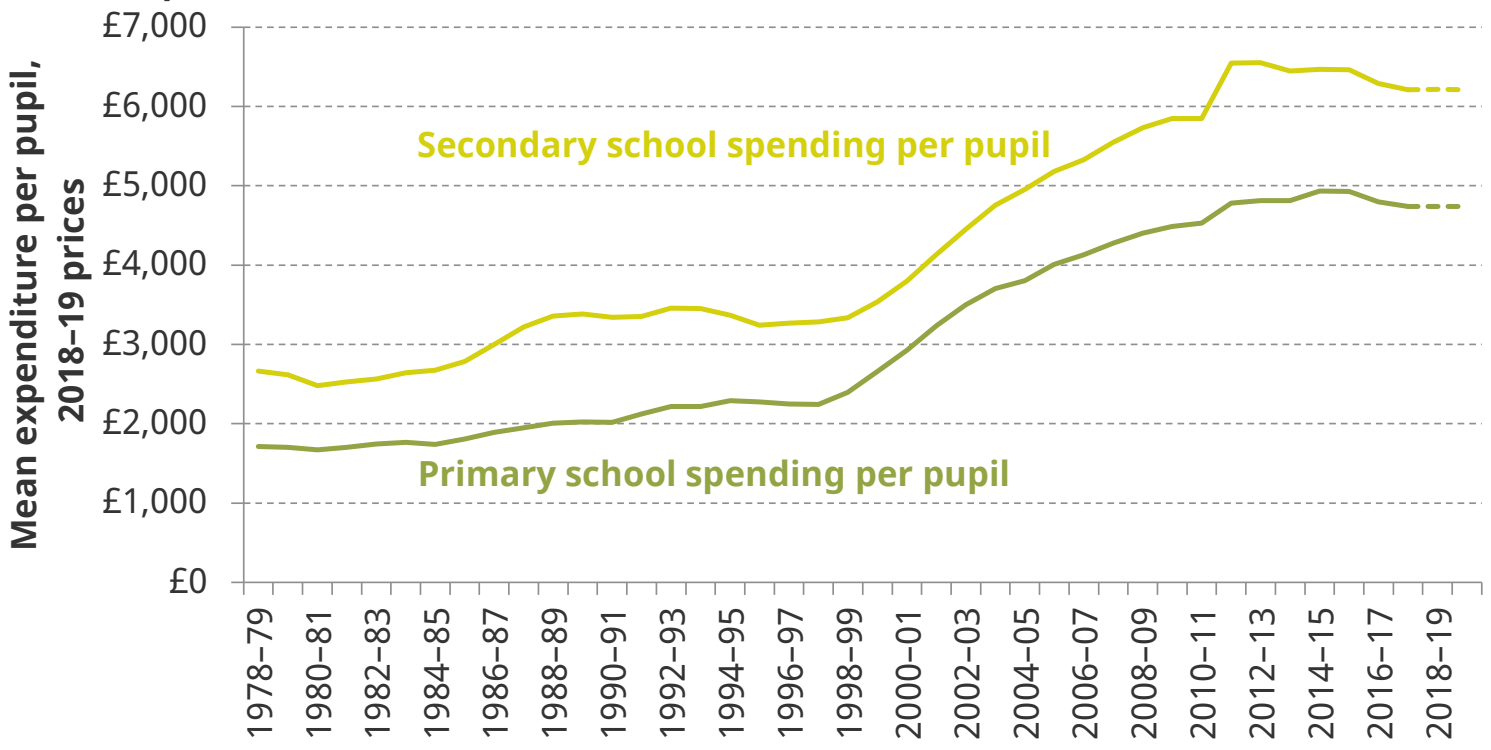

Note: Figures based on actual policy up to 2017-18 and policy announcements (dashed lines) up to 2019-20.

Source: See chapter 3 and figure 4.1 in Belfield and Sibieta (2016) for sources up to 2014-15. Figures for 2015-16 to 2019-20 nowcasted and projected based on final Dedicated Schools Grant allocations and Pupil Premium allocations: 2015-16 (https://www.gov.uk/government/publications/dedicated-schools-grant-dsg-2015-to-2016), 2016-17 (https://www.gov.uk/government/publications/dedicated-schools-grant-dsg-2016-to-2017), 2017-18 (https://www.gov.uk/government/publications/dedicated-schools-grant-dsg-2017-to-2018), 2018-19 (https://www.gov.uk/government/publications/dedicated-schools-grant-dsg-2018-to-2019) and 2019-20 (https://www.gov.uk/government/publications/national-funding-formula-tables-for-schools-and-high-needs2019-to-2020); Pupil Premium allocations taken from Kelly et al. (2018). Figures for 2019-20 also account for additional teachers' pay grant (https://www.gov.uk/government/news/government-to-fund-pay-rise-forteachers). HM Treasury deflators, March 2018 (https://www.gov.uk/government/statistics/gdp-deflators-atmarket-prices-and-money-gdp-march-2018-quarterly-national-accounts).

- Real-terms freeze between 2010 and 2015: Under the coalition government, existing school spending per pupil was frozen in cash terms from 2010-11 onwards, but the creation of the Pupil Premium (totalling around $£ 2.5$ billion by $2015-16^{25}$ ) ensured that total school spending per pupil was largely protected in real terms. Figure 3.1 shows a large apparent increase in 2011-12, which can be largely explained by inconsistencies in the data. ${ }^{26}$ Between 2011-12 and 2015-16, spending per pupil rose by 3\% in real terms in primary schools and fell by about $1 \%$ in secondary schools. These differing trends by phase of education can largely be explained by the fact that the Pupil Premium was gradually introduced at a higher rate in primary schools.

- Small real-terms falls since 2015: Between 2015-16 and 2017-18, school spending per pupil was frozen in cash terms, which translated into a real-terms cut of around $4 \%$, the first real-terms cut in per-pupil spending since the mid 1990s. These cuts were due to continue at a similar pace until 2019-20. However, the Department for Education

25 https://www.gov.uk/government/publications/pupil-premium-2015-to-2016-allocations.

26 These result from inconsistencies in the availability of data for academies (only available from 2011-12 and on a slightly different basis from maintained schools) and greater levels of funding and responsibilities devolved from local authorities to schools; see Belfield and Sibieta (2016) for more details. 
announced additional funding in both July 2017 and July 2018 (including both extra core funding and the creation of a teachers' pay grant). As a result, school spending per pupil will now be frozen in real terms between 2017-18 and 2019-20.

If existing plans for school funding are delivered, primary school spending per pupil will be about the same level in 2019-20 as in 2011-12 and secondary school spending per pupil will be about $5 \%$, or $£ 300$, lower than in 2011-12. Due to the large increases seen over the 2000s, however, spending per pupil will still be about 60\% higher than in 2000-01.

The figures above are based on an economy-wide measure of inflation: the GDP deflator, which is the measure of inflation most widely used to calculate real-terms changes in public spending across different areas. The actual costs faced by schools are likely to evolve differently in individual years, however. The main cost faced by schools is the cost of staff, which accounts for about three-quarters of school budgets and changes in them. Table 3.1 therefore shows estimates of changes in public sector pay per head over time, together with changes in the GDP deflator.

Under the coalition government, public sector pay per head rose by about $6 \%$ between 2010-11 and 2015-16, well below the 7.6\% level of economy-wide inflation seen over the period. This will have eased pressure on schools. Public sector pay was frozen for two years in 2011-12 and 2012-13, and increases were then capped at 1\% from 2013-14 onwards.

Between 2015-16 and 2019-20, however, we expect that public sector pay per head will grow by $10.6 \%,{ }^{27}$ outpacing growth in the GDP deflator by about 3 percentage points. This places additional pressure on school budgets. Increases in employer pension contributions and National Insurance contributions in April 2015 added to schools' costs, but these were partly balanced out by the fact that teacher salary increases were held at $1 \%$ per year up to 2018 . From September 2018 , the $1 \%$ public sector pay cap was lifted for

Table 3.1. Different measures for school cost growth between $2010-11$ and $2019-20$

\begin{tabular}{l|c|c}
\hline Measure of inflation & $\mathbf{2 0 1 0 - 1 1}$ to $\mathbf{2 0 1 5 - 1 6}$ & $\mathbf{2 0 1 5 - 1 6}$ to $\mathbf{2 0 1 9 - 2 0}$ \\
\hline GDP deflator & $7.6 \%$ & $7.3 \%$ \\
Public sector pay per head & $6.0 \%$ & $10.6 \%$ \\
\hline
\end{tabular}

Source: HM Treasury deflators, March 2018 (https://www.gov.uk/government/statistics/gdp-deflators-at-marketprices-and-money-gdp-march-2018-quarterly-national-accounts). Office for Budget Responsibility, Economic and Fiscal Outlook, various years: 2016-17 to 2019-20 taken from March 2018 forecast (http://obr.uk/efo/economicfiscal-outlook-march-2018/), 2015-16 taken from November 2016 forecast (http://obr.uk/efo/economic-andfiscal-outlook-november-2016/), 2014-15 taken from March 2015 forecast (http://obr.uk/efo/economic-fiscaloutlook-march-2015/), 2013-14 taken from March 2014 forecast (http://obr.uk/efo/economic-fiscal-outlookmarch-2014/), 2012-13 taken from December 2013 forecast (http://obr.uk/efo/economic-fiscal-outlookdecember-2013/), 2011-12 taken from March 2013 forecast (http://obr.uk/efo/economic-and-fiscal-outlookmarch-2013/) and 2010-11 taken from March 2012 forecast (http://obr.uk/efo/economic-and-fiscal-outlookmarch-2012/).

27 These figures are based on Office for Budget Responsibility forecasts made before the teacher pay announcement for September, but after the government made clear it was willing to accept settlements above the $1 \%$ pay cap. 
teachers. Classroom teachers on the main pay scale (about $40 \%$ of teachers ${ }^{28}$ ) saw increases of $3.5 \%$ and other teachers received a $2 \%$ increase. School leaders received a $1.5 \%$ rise.

\subsection{Wider measure of school spending}

The above analysis examined trends in spending by schools themselves on pupils aged up to 16 . This will cover the vast majority of day-to-day public spending on schools in England. It will, however, exclude spending on services by local authorities - for example, central spending on pupils with special educational needs, transport, educational psychology and other services provided to schools and pupils by local authorities. It will also exclude funding for school sixth forms. This is partly by design, as we analyse spending on school sixth forms in the next chapter. However, changes in funding for school sixth forms will clearly have important implications for the overall budgets of secondary schools with sixth forms.

Figure 3.2 therefore shows total school spending per pupil aged 3-19 broken down into three different components. The first includes spending per pupil directly allocated to

\section{Figure 3.2. Total school spending per pupil by component (2018-19 prices)}

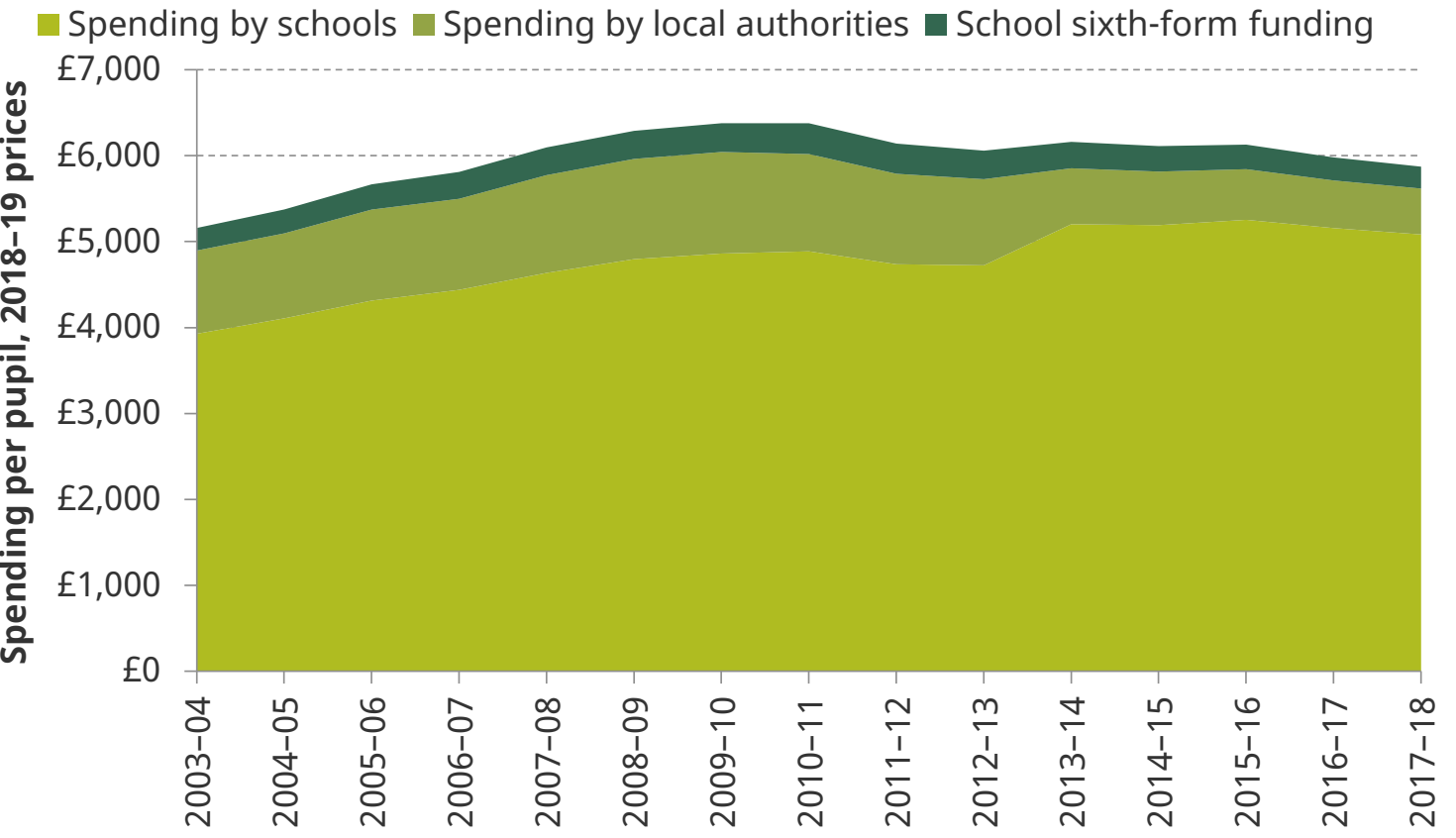

Note: All spending figures are divided by the number of full-time-equivalent pupils aged 3-19 in state-funded schools and early years settings.

Source: Authors' calculations using Section 251 out-turn data up to 2012-13 and Section 251 budget data from 2013-14 to 2017-18; Dedicated Schools Grant allocations 2010-11 to 2012-13 for academies' recoupment; Pupil Premium allocations 2011-12 to 2017-18; Department for Education, 'Schools, pupils and their characteristics', January 2010 to 2017; Department for Education, 'Education provision: children under 5', January 2010 to January 2017; HM Treasury deflators, March 2018.

28 Authors' calculations using School Workforce Census Statistics, November 2014

(https://www.gov.uk/government/statistics/school-workforce-in-england-november-2014). 
schools and early years providers. This includes budgets provided to early years providers because primary school budgets include funding for nursery pupils in some years. The second component includes spending on central services by local authorities. The third represents funding for school sixth forms. As we include early years and school sixth-form funding, figures are shown per full-time equivalent pupil aged 3-19 in school or early years settings (note that school sixth-form spending per pupil is lower than one might expect as it represents school sixth-form spending per pupil age 3-19, not per pupil in sixth forms).

In 2003-04 (the earliest year for which we can produce this set of figures in a consistent way), spending directly allocated to schools represented just under $£ 4,000$ per pupil (in 2018-19 prices) or about 76\% of total school spending per pupil, which stood at just under $£ 5,200$. The rest represented spending by local authorities (about $£ 1,000$ per pupil) and sixth-form funding (just over $£ 250$ per pupil).

As summarised in Table 3.2, over the six years up to 2009-10, each component rose by a similar amount in real terms. As such, the share of total spending directly allocated to schools remained at around $76 \%$ and total school spending per pupil rose by around $24 \%$.

After 2009-10, the different components evolved very differently. Spending per pupil directly allocated to schools rose by around $5 \%$ in real terms or about $£ 220 .{ }^{29}$ In contrast,

Table 3.2. Summary of levels and changes in different components of total school spending per pupil (2018-19 prices)

\begin{tabular}{l|c|c|c|c}
\hline & $\begin{array}{c}\text { Spending by } \\
\text { schools }\end{array}$ & $\begin{array}{c}\text { Spending by } \\
\text { local authorities }\end{array}$ & $\begin{array}{c}\text { School sixth-form } \\
\text { spending }\end{array}$ & $\begin{array}{c}\text { Total } \\
\text { spending }\end{array}$ \\
\hline $2003-04$ & $£ 3,928$ & $£ 969$ & $£ 262$ & $£ 5,159$ \\
Change & $+£ 934$ & $+£ 213$ & $+£ 73$ & $+£ 1,219$ \\
Real-terms & $+24 \%$ & $+22 \%$ & $+28 \%$ & $+24 \%$ \\
growth & & & & $£ 6,378$ \\
2009-10 & $£ 4,862$ & $£ 1,182$ & $£ 335$ & $-£ 506$ \\
Change & $+£ 222$ & $-£ 647$ & $-£ 80$ & $-8 \%$ \\
Real-terms & $+5 \%$ & $-55 \%$ & $-24 \%$ & \\
growth & & & & $£ 5,872$ \\
2017-18 & $£ 5,084$ & $£ 534$ & & \\
\hline
\end{tabular}

Note and source: See Figure 3.2

29 This increase is the result of a combination of factors working in opposite directions. First, policymakers intended to protect spending per pupil in real terms, on average, between 2010-11 and 2015-16. However, actual inflation turned out to be lower than expected. As a result, our analysis of Figure 3.1 confirmed that primary school spending per pupil rose by around 3\% in real terms between 2011-12 and 2015-16 and that secondary school spending per pupil was about constant in real terms (2010-11 to 2011-12 is excluded due to the aforementioned break in the series). Second, spending per pupil fell in real terms by around $4 \%$ between 2015-16 and 2017-18. Third, after 2011-12, a range of responsibilities and associated funding moved from local authorities to schools themselves. Analysis by Sibieta (2015) suggests this transfer of funding equated to about $3 \%$ of school budgets. Fourth, these figures will also include growth in early years spending reported in the previous chapter, though this is a relatively small share (less than $5 \%$ ) of total school spending. 
local authority spending on services fell by $55 \%$ or $£ 650$ per pupil in real terms between 2009-10 and 2017-18, and school sixth-form funding per pupil fell by about $24 \%$ or $£ 80$.

As a result of these contrasting trends, total school spending per pupil fell by about $8 \%$ or about $£ 500$ per pupil between $2009-10$ and $2017-18$. This is probably the best measure of the change in total public spending available for school services over this time. It includes the effect of cuts to local authority services, many of which schools will have had to fund from their existing budgets, and cuts to school sixth-form funding, which will have put pressure on secondary school budgets.

\subsection{Implementation of the National Funding Formula}

In April 2018, the government began implementing a new national funding formula for schools in England. Although less ambitious than originally planned, the new formula has started the reform process and will ensure that similar local authorities receive similar levels of funding per pupil.

Under the previous system, central government allocated a block of funding to English local authorities which they allocated to all state schools in their area using their own funding formulae. This resulted in a wide variation in funding per pupil across areas and schools in England. A lot of this was intentional: central government allocated more to local authorities in London to cover higher staff costs and successive governments have deliberately allocated more funding to schools in more deprived areas. However, some of the variation was unintentional and many schools with similar characteristics in different parts of the country receive different levels of funding. This is not a new phenomenon, however. It has been well known and persisted since at least the 1990s (West, West and Pennell, 1995).

These unintentional differences arose for two reasons. First, similar local authorities could receive quite different levels of funding per pupil from central government. This is because the amount going to each local authority was largely determined by their characteristics in the early 2000 s and local authorities have changed a lot since then. Second, schools in different local authorities could also receive different levels of funding per pupil because local authorities make different choices over how to allocate their school funding. This second type of variation may be desirable: it may reflect differences in local preferences or local policymakers responding to information on the ground.

Before the 2017 general election, the government set out ambitious plans for a national funding formula for schools in England. This would replace all 152 different local authority funding formulae with one single national funding formula applying to all state-funded schools. The intention was to eradicate the differences in funding levels between apparently similar schools and, in doing so, remove the role of local authorities in allocating school funding. Sensibly, the original proposals also included various protections and measures to prevent schools from seeing large changes in funding over a single year.

The government announced revised proposals in September 2017. The most important change was that the new National Funding Formula would not be fully implemented until at least 2020-21. There is a school-level formula, but it is only currently used to calculate 
how much each local authority receives. Local authorities are then free to allocate it (subject to statutory regulations) to the schools in their area according to their own funding formulae. There were also a number of specific changes to the formula, including minimum funding levels.

In July 2018 , the government published the funding formula factors that each local authority had chosen to put in place for April 2018. Interestingly, many local authorities chose to implement funding formulae close to or identical to the National Funding Formula. The Education and Skills Funding Agency (2018) reports that 73 out of 152 local authorities have chosen to bring every one of their funding formula factors close to the national funding formula levels, with 41 mirroring the formula exactly. In light of this, the government concluded that significant progress had been made towards implementation of a full National Funding Formula and delayed implementation of this formula until at least 2021-22 whilst the transition continues.

As it stands, the implementation of the National Funding Formula already means that - for the first time in nearly 15 years - there is now an actual school funding formula in England. As a result, we are already close to a situation where similar local authorities receive similar levels of funding per pupil. The fact that many local authorities have moved closer to or exactly mirrored the National Funding Formula means that we are also a bit closer to a situation where similar schools receive similar levels of funding. However, because local authorities can implement their own local funding formulae, similar schools across different areas can still receive quite different levels of funding per pupil.

Under the original hard national funding formula, only $60 \%$ of schools were due to be on the main formula by 2019-20, with the rest protected by the various floors and caps implemented to ease the transition. Additional protections announced in September 2017 mean that we would now expect only about $40 \%$ of schools to be on the main formula by 2019-20. ${ }^{30}$ As not all local authorities have mirrored the national funding formula, the true figures will actually be lower than this. Getting more schools onto the national funding formula will require two things. First, the cap on gains will gradually need to be removed, which will clearly require additional public spending. Second, schools protected by the cap on losses and funding floors will need to see below-average increases in funding so that their actual funding levels gradually fall back to those implied by the formula. This does not necessarily require additional public spending, but it is clearly easier to deliver belowaverage increases when the average is a high one, and much harder when the average is a low one.

\subsection{Summary}

Since 2015, schools have faced their first real-terms cuts in about 20 years. However, these come on the back of significant rises over the 2000s and will still leave per-pupil spending by schools about $60 \%$ higher than in 2000.

Despite this, there are other reasons to believe that schools face significant resource pressures. Public sector pay freezes up to 2015 mean that the growth in schools' actual costs was probably below the rate of inflation, easing the pressure on schools. However,

30 Authors' calculations using National Funding Formula allocations for schools 2019-20

(https://www.gov.uk/government/publications/national-funding-formula-tables-for-schools-and-high-needs). 
various extra costs for employers and the removal of the public sector pay cap mean that schools' costs are likely to have significantly outpaced inflation after 2015, adding to pressure on school budgets.

Although spending by schools themselves has risen by $5 \%$ or $£ 220$ per pupil between 2009-10 and 2017-18, they have taken responsibility for many services previously provided by local authorities, where spending has fallen by more than $50 \%$ or $£ 650$ per pupil. Incorporating cuts to local authority spending and sixth-form funding, total school spending per pupil has fallen by $8 \%$ in real terms over the same period and was only about 14\% higher in 2017-18 than in 2003-04.

The government is also part-way through implementing a new national funding formula, the most ambitious reform to the school funding system in over 25 years. This is currently only being used to determine allocations to local authorities, which will ensure that broadly similar local authorities receive similar levels of funding. The implementation of a full school-level national funding formula has been put off until at least 2021, which is unsurprising as this would clearly require quite a lot more shifts in funding across schools. 


\section{Further education and skills}

At age 16, young people face a range of education and employment options. They can continue in full-time education at a school sixth form, sixth-form college or further education college. Of those continuing in full-time education, most will take A levels. However, there is a vast range of other vocational qualifications on offer, particularly at further education colleges. Young people can combine part-time work and education or training, including in an apprenticeship. Historically, many young people have also opted to move straight into paid employment, though this has become less common over time.

The further education sector also provides education and training for adults, which has historically been the main focus of the sector. There is currently a vast range of education and training options available at this stage, including formal education qualifications in classroom-based settings (usually taken part-time), apprenticeships and shorter training courses, as well as basic courses in English and maths.

Table 4.1 documents the large number of major reforms, formal reviews and changes to the further education sector since 2000. New modular AS/A levels were introduced in 2000, with a return to $A$ levels with final exams in 2015 . Vocational qualifications have been subject to continual reform and debate. 14-19 diplomas were introduced in the late 2000s (and then scrapped in 2013). The 2011 Wolf Review concluded that many vocational qualifications taken by young people were of little economic value, leading to substantial reform to what qualifications were publicly funded and counted towards performance tables. Following on from recommendations in the 2016 Sainsbury Review (Independent Panel on Technical Education, 2016), the government now plans to introduce new 'T levels' from 2020.

From 2013, the participation age - the age when young people are allowed to leave education or training - was gradually raised from 16 to 18 , such that all young people are now expected to be in some form of education or training (either full-time or part-time). The original 2008 legislation intended this to be compulsory, with penalties for young people and employers ignoring the legislation. The new coalition government decided not to apply any of these penalties, and compliance has largely been voluntary.

The funding system for education has also changed significantly over time, with the introduction of a new National Funding Formula for 16-19 education in 2013 and a new funding condition from 2014 that removed funding from colleges where young people were not enrolled in English and maths (if they had not previously achieved a grade $\mathrm{C}$ or above in English and maths at GCSE). Various funding agencies have also been responsible for funding over the years: Learning and Skills Council (2001 to 2010); Young People's Learning Agency (2010 to 2012); Skills Funding Agency (2010 to 2017); Education Funding Agency (2010 to 2017); Education and Skills Funding Agency (2017 to present day). A new adult education budget combining the non-apprenticeship part of the adult skills budget, community learning, and discretionary learner support was introduced in 2016. Advanced learner loans were first introduced in 2013 for students aged 24 and up taking Level 3 and 4 qualifications, then extended to all students aged 19 and over and all qualifications from Level 3 to 6 three years later.

The funding system and overall policy framework for training have also been subject to significant changes. Individual Learner Accounts (introduced in 2000) sought to provide 
financial incentives for adults to take more education and training, but were scrapped in 2001 following significant fraud. The Skills for Life strategy sought to improve the basic numeracy and literacy of adults and young people, with various targets set out in the strategy and the Leitch Review of 2006, as well as specific Skills for Life courses. Train to Gain provided incentives, funding and advice to try to increase the number of adults with Level 2 vocational qualifications, but was then scrapped by the incoming government in 2010. Since then, governments have increasingly focused on apprenticeships, with targets for 2 million new apprenticeship starts between 2010 and 2015, 3 million between 2015

Table 4.1. Major reform to further education and skills since 2000

\begin{tabular}{l|l}
\hline Year & Description \\
\hline 2000 & Introduction of AS levels \\
2000 & Introduction of Individual Learner Accounts (scrapped 2001) \\
2001 & Creation of Learning and Skills Council (scrapped 2010) \\
2001 & Launch of Skills for Life strategy \\
2006 & Leitch Review of Skills \\
2006 & Introduction of Train to Gain (scrapped 2010) \\
2008 & Removal of age-25 age limit for apprenticeships \\
2008 & Introduction of 14-19 diplomas (scrapped 2013) \\
2010 & Creation of Young People's Learning Agency (scrapped 2012) \\
2010 & Government target for 2 million new apprenticeship starts (2010 to 2015) \\
2010 & Creation of Education Funding Agency (merged 2017) \\
2010 & Creation of Skills Funding Agency (merged 2017) \\
2011 & Wolf Review of Vocational Education \\
2013 & Introduction of National Funding Formula \\
2013 & Start of rise in education participation age from 16 to 18 \\
2013 & Introduction of advanced learner loans for Level 3 and 4 learners aged 24 and up \\
2014 & Introduction of English and maths funding condition \\
2015 & Government target for 3 million new apprenticeship starts (2015 to 2020) \\
2015 & Introduction of new A levels \\
2016 & Extension of advanced learner loans to learners aged 19+ and courses at Levels 5 \\
2016 & and 6 \\
2016 & Introduction of adult education budget combining three existing funding streams \\
2017 & Introduction of Apprenticeship Levy \\
\hline 2017 & Creation of Education and Skills Funding Agency \\
\hline 20 & Planned introduction of T levels \\
\hline
\end{tabular}


and 2020, and the introduction of the Apprenticeship Levy and a new system of funding in May 2017.

Given this near-permanent state of revolution in the further education sector and the long-run squeeze on funding seen in our previous work (Belfield, Crawford and Sibieta, 2017), we have chosen to write a special focus on the funding and organisation of 16-19 and 19+ further education in this first annual report. We start in Section 4.1 by describing trends in the overall numbers of learners taking each route. In Section 4.2, we examine the overall levels of funding and funding per student over time. In Section 4.3, we describe the overall structure of the funding systems, what incentives these create and how they drive differences in funding across routes and individuals. Finally, in Section 4.4, we describe planned future reforms and the challenges facing the sector in the near future.

\subsection{Participation trends}

While the further education (FE) system serves both young people (ages 16-19) and adults, there are important differences between the age groups both in how the FE system is structured and in the mix of qualifications that learners take. In this section, we describe the different routes and qualifications available and show how learner numbers in each route have changed over time.

\section{6-19 education}

Figure 4.1 shows the proportion of 16- and 17-year-olds in England taking different education and employment options over time. We focus on this age group as, by age 18, many young people have moved into higher education, which is covered in the next chapter. However, this still leaves about 115,000 18-year-olds - 18\% of the age group - still in further education (Department for Education, 2018a).

As Figure 4.1 makes clear, an ever higher proportion of 16- and 17-year-olds have decided to stay in full-time education over time. The proportion in full-time education has more than doubled since the mid 1980 s, rising from $40 \%$, to $65 \%$ in the mid 1990 s, to around $70 \%$ by the mid 2000 s and again up to $82 \%$ at the latest count in 2017 . This growth has been more or less evenly split between school sixth forms, FE and sixth-form colleges, and independent schools, each of which now accounts for around twice the share of young people as in 1985.

At the same time, the proportion of young people in work-based learning, which includes apprenticeships, has fallen from around $15 \%$ in the mid 1980 s to around $10 \%$ by the mid 1990s and has remained around 5\% since 2010. The lack of change since 2010 is surprising given the high-profile government focus on encouraging more young people to take an apprenticeship.

The proportion in other forms of part-time education or training has also fallen sharply, from around $14 \%$ in the mid 1980 s to around $7 \%$ in 2017, whilst the proportion going straight into employment (without any education or training) has fallen even more sharply over time, from $21 \%$ in 1985 to about $2 \%$ in 2017. 


\section{Figure 4.1. Percentage of 16- and 17-year-olds taking different education and employment choices}

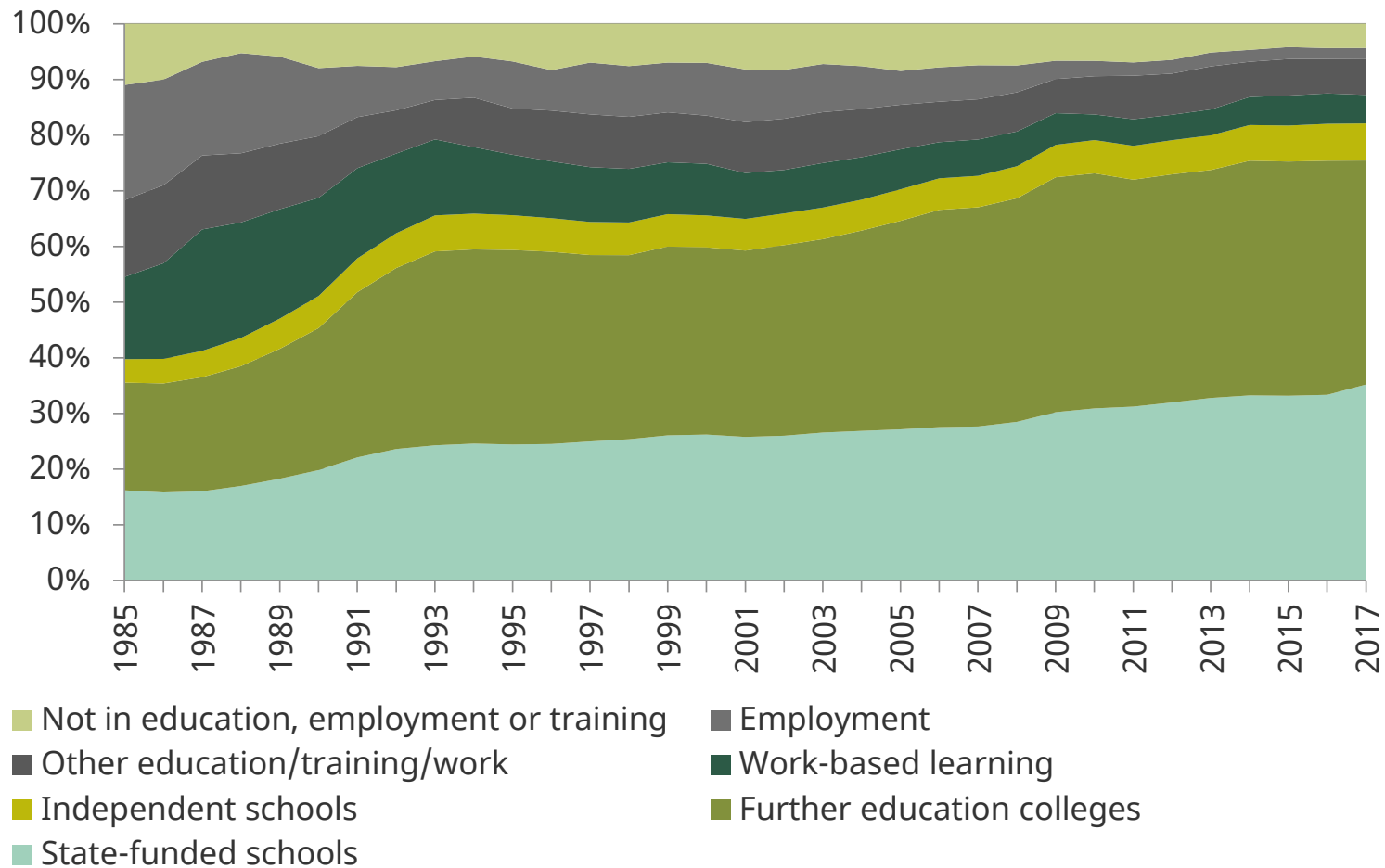

Note: 'State-funded schools' and 'further education colleges' include only pupils in full-time education. 'Further education colleges' includes sixth-form colleges. 'Work-based learning' includes apprenticeships. 'Other education/training/work' includes any option that combines paid employment with part-time education or training.

Source: Authors' calculations using Department for Education, 'Participation in education, training and employment: 2017' (https://www.gov.uk/government/statistics/participation-in-education-training-andemployment-2017).

Encouragingly, the proportion of 16- and 17-year-olds not in any form of education, employment or training (so-called NEETs) has fallen from about $11 \%$ in 1985 to about $7 \%$ in 2000, and most recently stood at 4\% in 2017.

The proportion of young people not in any education or training (NEETs and those in employment without education) was about $6 \%$ in 2017. Although down from $9 \%$ in 2010 , this strongly suggests that the new legal participation age of 18 is not being fully enforced.

Hupkau et al. (2017) describe the different qualification routes available to young people after the age of 16 and summarise some key characteristics about the young people who take each route (based on a cohort taking their GCSEs in 2010). They also show that routes can often be combined. However, based on their highest qualification aims, the main routes can be summarised as follows:

- A/AS levels (55\% of 16- and 17-year-olds in 2017): Although down from around twothirds in the mid 1990s, this remains the predominant academic route for young people after finishing school at age 16 . Individuals taking this route have generally performed 
well at GCSE, with around $90 \%$ having obtained at least five GCSEs at A*-C including English and maths (Hupkau et al., 2017).

- Other Level 3 qualifications (22\% of 16- and 17-year-olds in 2017): These are mainly comprised of vocational qualifications, including Applied Generals (usually BTEC diplomas), $T$ levels and other Level 3 qualifications. The proportion taking these qualifications has risen sharply since the mid 1990s, when it stood at around 9\%. These individuals tend to have performed less well at GCSE compared with those taking $A$ levels, with about $56 \%$ achieving at least five GCSEs at $A^{*}-C$ including English and maths. They are also more disadvantaged, on average, with over a quarter ever having been eligible for free school meals, compared with $16 \%$ of those taking A levels (Hupkau et al., 2017).

- GCSEs and other Level 2 qualifications (16\% of 16- and 17-year-olds in 2017): Unsurprisingly, young people in this group performed even less well at GCSE at age 16, with just over $10 \%$ achieving the benchmark of at least five GCSEs at $A *-C$ including English and maths. They are also more disadvantaged, with around $40 \%$ having ever been eligible for free school meals (Hupkau et al., 2017). Since 2013, a much larger share of 16- and 17-year-olds are taking GCSEs as their highest qualification, rising from about $3.5 \%$ in 2013 to nearly $12 \%$ by 2017 . This is almost certainly driven by the new funding condition that removes funding from colleges if young people who have not achieved a grade $\mathrm{C}$ or above in GCSE-level English and maths are not enrolled in those courses.

- Qualifications below Level 2 (4\% of 16- and 17-year-olds in 2017): This group is even more disadvantaged on average (with 50\% ever having been eligible for free school meals) and very unlikely to have achieved the standard benchmark of at least five GCSEs at $A^{*}-C$ including English and maths (Hupkau et al., 2017).

Figure 4.2 shows the changes over time in the proportions of 16- and 17-year-olds taking different types and levels of qualifications in (a) school sixth forms, (b) sixth-form colleges and (c) further education colleges. In each case, we allocate young people to the highestlevel qualification they are studying for - e.g. students studying A levels and GCSEs are in the A-level group.

The figure very clearly shows that A/AS levels represent the dominant mode of study for young people in school sixth forms, and increasingly so over time. In 1994, about $80 \%$ of young people in school sixth forms were studying for A/AS levels, and this rose to a high of $92 \%$ by 2007 , though it has since fallen back a little to around $87 \%$ in 2017 . There has also been a rise in the proportion taking other Level 3 qualifications, such as Applied Generals (usually BTEC diplomas), which has risen from close to zero in 1994 to about 11\% in 2017. At the same time, there has been a big fall in the proportion taking GCSEs, GCSEequivalent or lower qualifications, to about $3 \%$ in 2017. School sixth forms have thus become increasingly focused on A levels and, to a lesser extent, A-level-equivalent qualifications.

We see a similar picture for sixth-form colleges. The proportion taking A/AS levels has fallen slightly from around $83 \%$ in 1994 to about 74\% in 2017, whilst the proportion taking other Level 3 qualifications has risen from near zero in 1994 to about 18\% in 2017. When 
Figure 4.2. Proportion of 16- and 17-year-olds in full-time education taking different levels/types of educational qualifications

\section{a) School sixth forms}

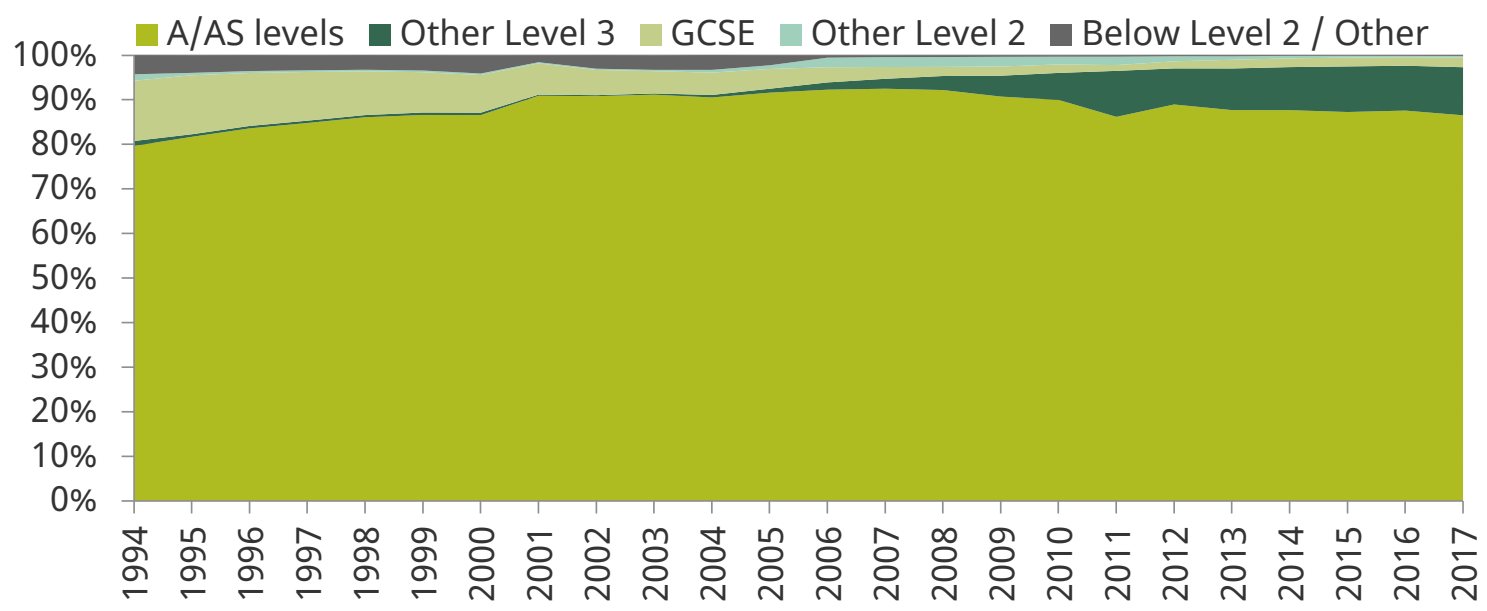

\section{b) Sixth-form colleges}

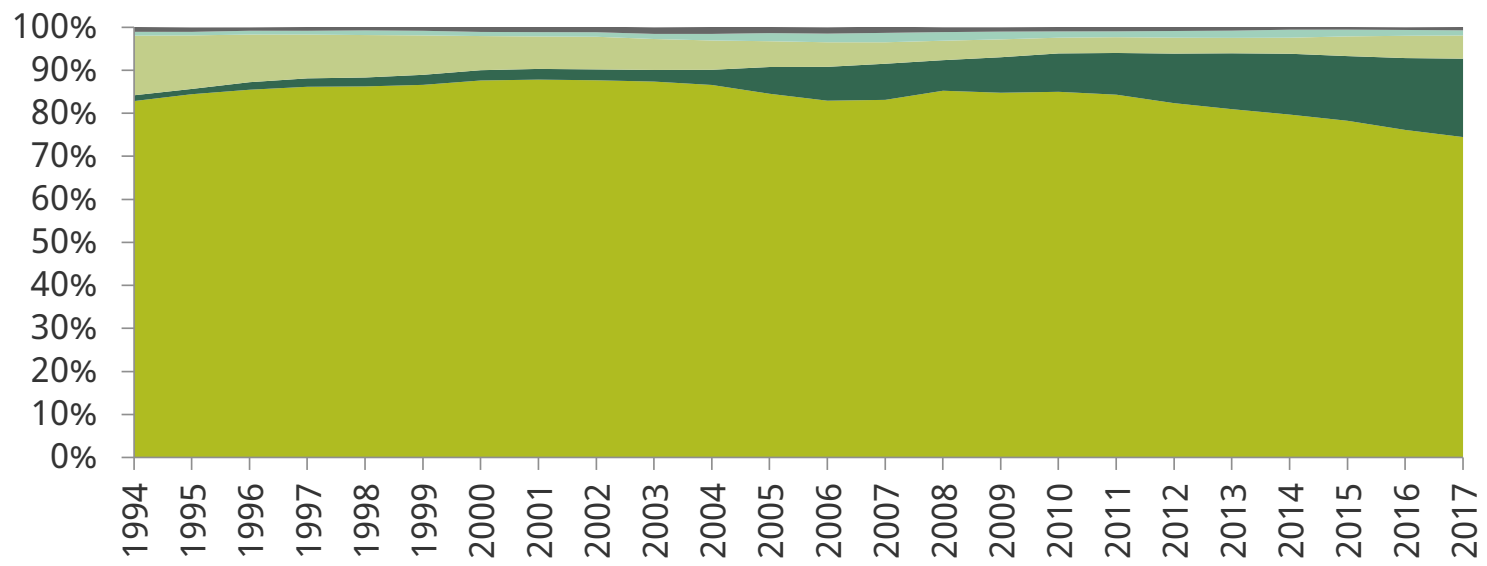

\section{c) Further education colleges}

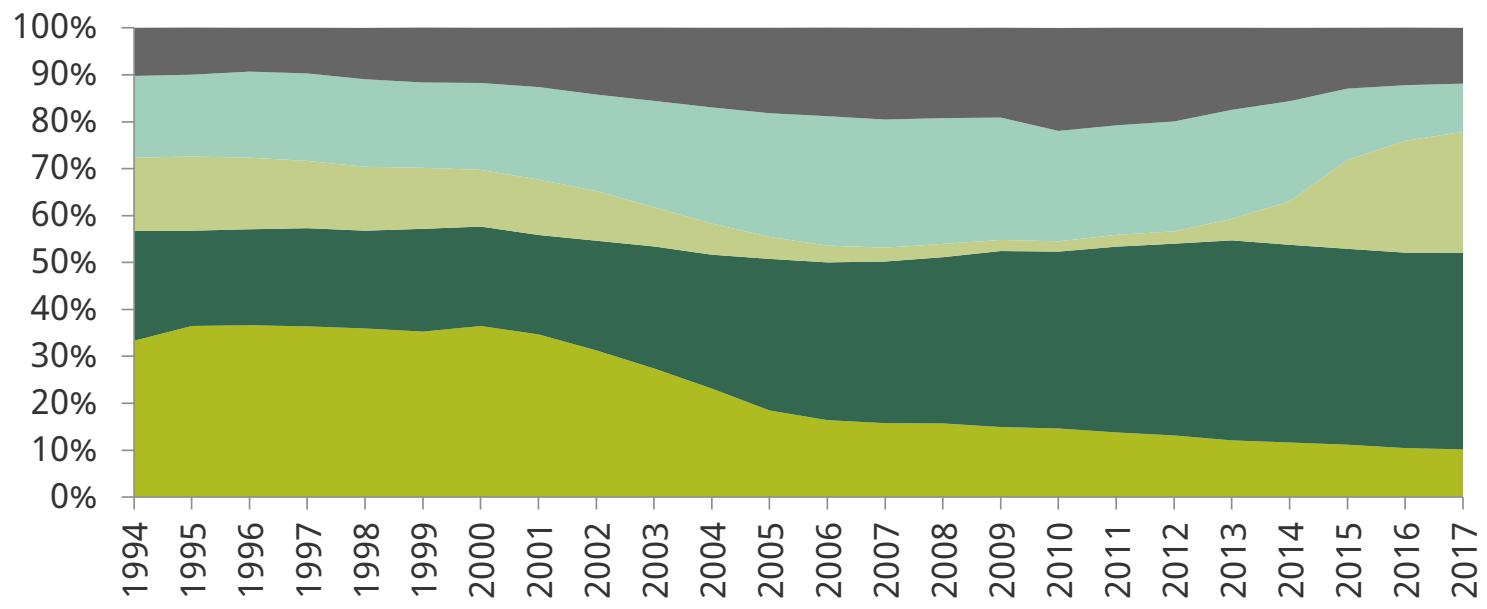

Source: Authors' calculations using Department for Education, 'Participation in education, training and employment: 2017' (https://www.gov.uk/government/statistics/participation-in-education-training-andemployment-2017). 
combined, this makes for about 93\% taking A/AS or other Level 3 qualifications in 2017 and only about $7 \%$ taking GCSEs or lower qualifications.

The pattern for further education colleges looks very different, both in terms of the qualifications being taken today and in terms of the shifts over time. Around half of FE college students study Level 3 qualifications (A/AS levels or other Level 3), compared with the very large majority in school sixth forms and sixth-form colleges. A further third $-36 \%$ - are studying a Level 2 qualification (GCSEs or other Level 2). The remaining students around $12 \%$ - are studying qualifications below Level 2 or other types of qualifications. Some of this difference relative to sixth forms and sixth-form colleges is driven by FE colleges' greater historical focus on vocational and technical qualifications, which remains to this day.

Within each qualification level at FE colleges - A/AS levels and other Level 3, GCSEs and other Level 2, and below Level 2 - the share of students in 2017 was roughly similar to the share in 1994. However, within these levels, there has been a significant shift between qualification types. The most notable change has been the shift away from A/AS levels and towards other Level 3 qualifications. In the mid 1990s, around a third of 16- and 17-yearolds in FE colleges in England were taking A/AS levels. This fell to about 15\% in 2010 and $10 \%$ in 2017. At the same, there has been a big shift towards other Level 3 qualifications, from about 20\% in the mid 1990s to about $42 \%$ in 2017.

GCSEs have become a more popular route within Level 2 qualifications in FE colleges. In the mid 1990s, the proportions were split roughly evenly between students taking GCSEs and students taking other Level 2 qualifications. By 2010, of the $26 \%$ taking GCSE or other Level 2 qualifications, 2 percentage points were taking GCSEs. Since 2013, the proportion of FE college students taking GCSEs as their highest aim has risen from under $5 \%$ to about $26 \%$ in 2017 . This is almost certainly driven by the English and maths GCSE funding condition introduced in 2014. Indeed, about two-thirds of students taking GCSEs in 2017 were also taking other Level 2 qualifications.

A significant share of students in FE colleges take qualifications below Level 2. This stood at $12 \%$ in 2017, about the same level last seen in the 1990s. However, the proportions rose substantially over the 2000 s to reach a high of $22 \%$ in 2010 . The recent fall back to $12 \%$ seems likely also to be driven by the new English and maths funding condition.

While the changes across qualification types between 1994 and 2017 in FE colleges have been notable, the most dramatic changes occurred in the intervening years. Prior to the mid 2000s, there was a steady shift away from GCSEs and A/AS levels and into other Level 2 and Level 3 qualifications. Since then, the share taking A/AS levels has continued to fall, albeit at a much slower rate.

The 2011 Wolf Review of Vocational Education argued that a focus on Level 2 qualifications (and below), much more common in FE colleges, was detrimental to young people's employment opportunities, given that many of these qualifications have been found to have very low economic returns. The review also argued that the shift towards such qualifications was driven by a combination of regulation - which gave parity to GCSES and Level 2 qualifications - and a funding system that generated incentives to take a large number of qualifications with a high chance of success. The Wolf Review instead proposed a greater focus on GCSEs - English and maths in particular - and a move from funding 
individual qualifications to funding individual students. The government implemented many of these reforms by 2013, including the new 16-19 National Funding Formula (see Section 4.3) and the English and maths funding condition. Since then, there has been a rapid and remarkable recovery in the proportion of FE college students taking GCSEs rather than other Level 2 qualifications.

We therefore see markedly different types of qualifications being taken in school sixth forms and sixth-form colleges on the one hand and in further education colleges on the other hand, with pupils at school sixth forms and sixth-form colleges much more likely to be taking academic qualifications in the form of A/AS levels. We also see very different trends over time. For school sixth forms and sixth-form colleges, we see a gradual shift towards A/AS levels and other Level 3 qualifications; the shift towards other Level 3 qualifications is larger for sixth-form colleges. By contrast, for further education colleges, we see an even bigger shift away from A levels towards other Level 3 qualifications (though only a slight fall in the proportion taking Level 3 qualifications in total). We also see little net change in the proportion of young people at colleges taking Level 2 qualifications or below. However, this masks a big rise and then fall in the proportion taking other Level 2 qualifications, and in the proportion taking qualifications below GCSE level, and a fall and then a big rise in the proportion taking GCSES.

\section{9+ further education}

In addition to providing education for young people, the further education sector also provides education and training for adults, which has historically been the main focus of the sector. There is a vast range of education and training options available at this stage and providing a comprehensive summary of them is beyond the scope of this report. Instead, we provide an overall summary of the number of learners and the type/level of qualifications they undertake.

Figure 4.3 shows the total number of learners aged 19 and older over time, as well as the number taking different levels of educational qualifications. The numbers taking each level are further broken down by whether they were taking an apprenticeship or other route. Learners taking multiple qualifications can be in more than one category, so the total number of learners is less than the sum of the categories.

The total number of learners has fallen substantially over time, from a high point of 4.7 million in 2004 to 3.2 million by 2010, and to 2.2 million in 2016 at the latest count. A large part of this 2.4 million fall can be accounted for by a reduction in the numbers taking low-level qualifications (Skills for Life, English and maths; below Level 2; and no level), which fell by 1.9 million from around 3.6 million in 2004 to 2.2 million in 2010 and 1.7 million in 2016.

Between 2005 and 2010, the falls were mainly driven by reductions in the number taking qualifications below Level 2. However, from 2011 onwards, there are also falls in the numbers taking Skills for Life or English and maths qualifications, from 1.1 million in 2011 to 750,000 by 2016 . This reverses about half the growth in such qualifications seen since the major Skills for Life strategy was introduced in 2001.

McNally (2018) show that most of the overall fall in the number of adult learners after 2005 comes from falls in the number of over-25s taking low-level qualifications. They argue that this was driven by the new skills strategy adopted at that time, which removed public 
Figure 4.3. Total number of 19+ learners taking different educational qualifications over time
Level 4 - apprenticeship
Level 4 - other
Level 3 - apprenticeship
Level 3 - other
Level 2 - apprenticeship
Skills for Life / English / maths
Level 2 - other
No level
Below Level 2
$\longrightarrow$ - TOTAL LEARNERS

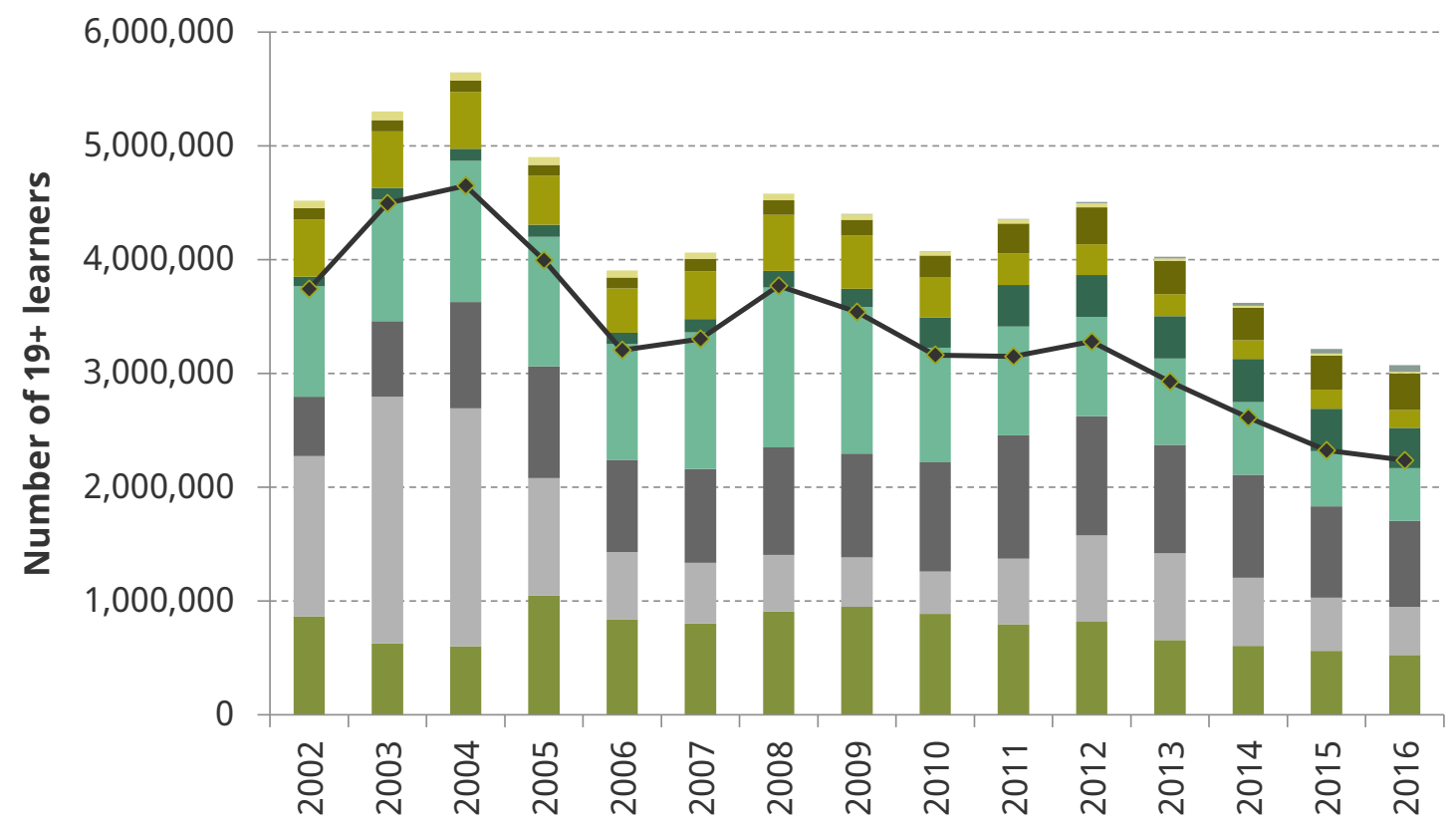

Note: Individuals can be taking more than one type of qualification and the total number of learners is therefore lower than the sum of the categories.

Source: Authors' calculations using Department for Education, 'Further education and skills: March 2018' (https://www.gov.uk/government/statistics/further-education-and-skills-march-2018).

funding from a number of small, low-level qualifications, which were thought to be of little economic value.

The numbers taking Level 2 and Level 3 qualifications have also fallen over time, though not quite to the same degree as seen for lower-level qualifications:

- The total number taking Level 2 qualifications remained around 1.2-1.3 million up to 2012 and has since fallen to around 800,000 in 2016.

- The number taking Level 3 qualifications reached a high point of over 600,000 in 2008 , but has since fallen back to just under 500,000.

Within both Level 2 and Level 3 qualifications, however, there has been a dramatic shift towards apprenticeships and a movement away from classroom-based learning. The number of adults taking Level 2 apprenticeships rose from around 100,000 in 2006 to reach about 350,000 in 2016, and they make up nearly half of all Level 2 adult learners (compared with less than $10 \%$ in 2006). Similarly, the number of adult Level 3 apprenticeships has gone up from 100,000 in 2006 to about 300,000 in 2016, and they make up two-thirds of all Level 3 qualifications undertaken by adults. Most of this increase comes from apprentices aged 25 or older, as shown by Amin-Smith, Cribb and Sibieta 
(2017) and McNally (2018) - a group which had not existed prior to the removal of the upper age limit on apprenticeships in 2008.

The number of adult learners taking qualifications at Level 4 or above is very small in the context of the overall number of adult learners. In 2016, this accounted for around 75,000 learners (just over $3 \%$ of total adult learners), and around four-fifths of these were doing an apprenticeship.

From May 2017, the Apprenticeship Levy (see Section 4.3 for further details) was introduced as part of an effort to meet the government's target of 3 million new apprenticeship starts between 2015 and 2020. However, the number of apprenticeship starts appears to have fallen in the latest data. There were 290,000 apprenticeship starts in the first three quarters of 2017-18, which compares with around 450,000 at the same point in the cycle in 2016-17 (Powell, 2018). It is not yet clear whether this downward trend is a permanent trend or a temporary blip as part of the transition to the new Apprenticeship Levy system.

Whilst overall numbers are down, the number starting the highest-level apprenticeships (Level 4 or above) in the first three quarters of 2017-18 are already at the same level as for the whole of 2016-17. However, the number of such higher-level apprenticeship starts is still relatively small, at about 35,000 or just over $10 \%$ of all apprenticeship starts.

In summary, the number of 19+ adult learners has fallen substantially over time, driven mostly by falls in the number of adults taking low-level qualifications and a greater focus by policymakers on qualifications at Level 2 or above. Furthermore, a much larger share of adult learning takes the form of apprenticeships, with these now making up around half of all Level 2 qualifications and two-thirds of Level 3 qualifications.

\subsection{Spending levels}

In this section, we detail overall levels of spending on further education and skills, before showing levels of spending per student over time.

\section{Overall spending}

Figure 4.4 shows the total level of day-to-day spending on various elements of further education and skills in England from 2002-03 through to 2017-18, including both 16-18 education and adult skills spending. In all cases, this represents allocations from central government, rather than actual spending. For example, we show allocations to school sixth forms, rather than spending by schools on sixth-form education.

Total spending on 16-18 education (including FE and sixth-form colleges, school sixth forms and 16-18 apprenticeships) stood at $£ 6.5$ billion in 2017-18. Reflecting the increases in post-16 participation amongst young people in England, total spending has generally grown rapidly over time:

- Between 2002-03 and 2009-10, spending on FE and sixth-form colleges grew by $65 \%$ in real terms, whilst spending on school sixth forms rose by $33 \%$. This reflects the fact that a larger part of the increase in post-16 participation was absorbed by FE and sixth-form colleges than by school sixth forms. 
Figure 4.4. Total spending on further education and skills

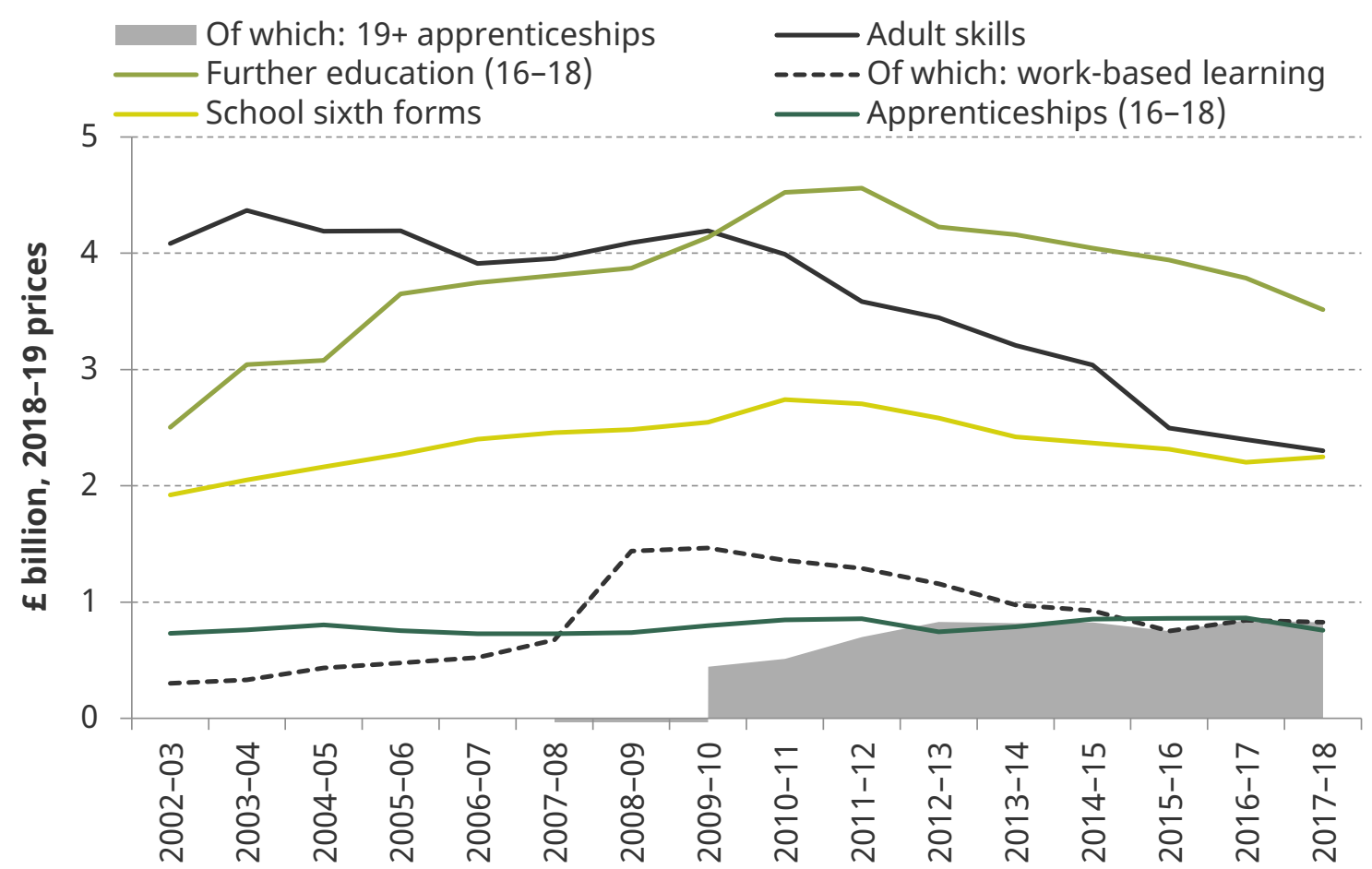

Note: 'Adult skills' includes all 19+ skills expenditure (excluding higher education and offender learning). 'Workbased learning' includes Train to Gain and 19+ apprenticeships. 'Further education' includes expenditure on FE and sixth-form colleges. 'School sixth forms' includes expenditure on sixth forms in academies and maintained schools.

Source: Authors' calculations using Education and Skills Funding Agency annual report and accounts 2017-18 (https://www.gov.uk/government/publications/education-and-skills-funding-agency-annual-report-andaccounts-2017-to-2018), Skills Funding Agency annual reports and accounts 2010-11 to 2016-17

(https://www.gov.uk/government/collections/sfa-annual-reports-and-accounts) and Department for Innovation, Universities and Skills departmental report 2009

(https://assets.publishing.service.gov.uk/government/uploads/system/uploads/attachment_data/file/238617/75 96.pdf). Adult Skills include all 19+ skills expenditure (excluding higher education and offender learning).

- Since 2009-10, total spending has fallen back in real terms, with spending on school sixth forms falling by $12 \%$ and spending on $16-18$ further education falling by $15 \%$.

- Total spending on apprenticeships for 16 - to 18-year-olds stood at about $£ 800$ million in 2017-18 (2018-19 prices) and has been at this level since the early 2000s. Spending earlier in the 2000s included a number of other youth training schemes, which have since been abolished. It is therefore likely that spending specifically on apprenticeships has grown slightly over time.

Funding for adult education and apprenticeships stood at $£ 2.3$ billion in 2017-18 (in 201819 prices). Around half of this represents 19+ further education in classroom settings, about a third represents spending on work-based training for individuals aged 19+ (which includes apprenticeships) and the rest is made up of smaller programmes such as community learning.

Total spending on adult skills was largely constant in real terms between 2002-03 and 2009-10, at just over $£ 4$ billion in 2018-19 prices. However, it fell by about $45 \%$ in real 
terms between 2009-10 and 2017-18. Within this total budget, the composition of spending has shifted significantly towards work-based learning: in 2002-03, spending on apprenticeships and other work-based learning represented about $7 \%$ of adult skills spending; in 2017-18, it accounted for over one-third.

Spending on apprenticeships and other work-based learning for adults has fallen since $2009-10$ by about $44 \%$ in real terms. However, most of this fall can be explained by the rapid increase in expenditure on 'Train to Gain' between 2007-08 and 2009-10 and the subsequent winding down of spending on it up to 2014-15. Specific spending on 19+ apprenticeships doubled from around $£ 400$ million in $2009-10$ to $£ 800$ million in 2017-18.

Spending on adult skills has thus fallen significantly since 2009-10 and a greater share now comes from apprenticeships for individuals aged 19 or over.

\section{Spending per student}

Figure 4.5 shows the level of spending per student in further education (16-18) and school sixth forms over time. Projections up to 2019-20 are based on the existing policy of a cashterms freeze in the national base rate, expected population growth and additional funding for the introduction of $\mathrm{T}$ levels. For simplicity and given that most providers selected to implement T levels from 2020 are colleges, we assume all of the extra funding for T levels goes to FE and sixth-form colleges.

Starting with FE and sixth-form colleges, spending per student has evolved in three distinct phases.

Figure 4.5. Spend per FTE student in 16-18 further education and school sixth forms

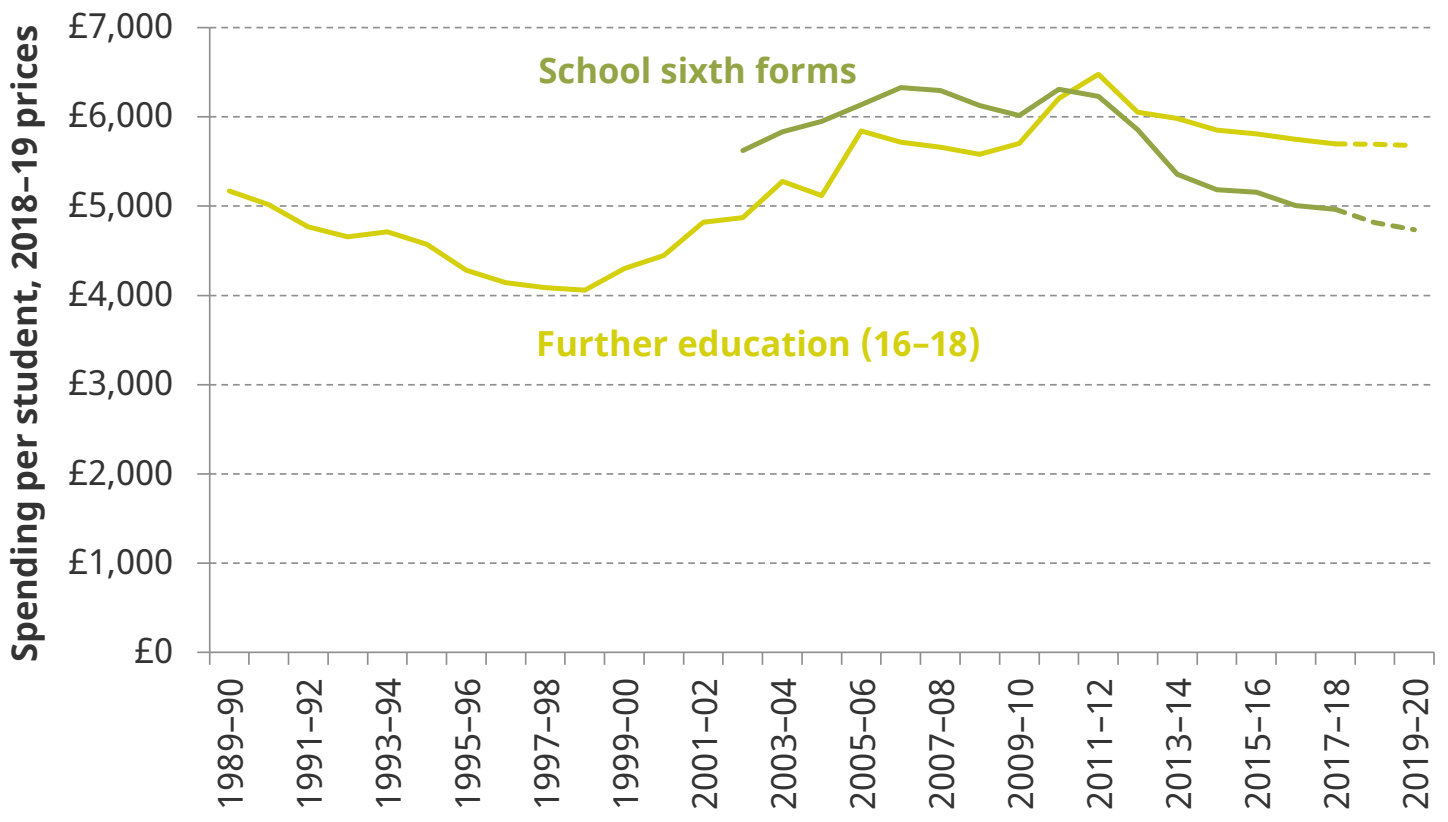

Note: Number of full-time-equivalent (FTE) students is calculated as number of full-time students plus 0.5 times number of part-time students.

Source: See Appendix B. 
- In 1989-90, spending per student stood at around $£ 5,000$ (in 2018-19 prices). It then fell by nearly $22 \%$ in real terms over the course of the 1990 s to reach a low of $£ 4,100$ per student in 1998-99.

- After that, spending per student rose significantly, by just under $60 \%$ in real terms to reach a level of around $£ 6,500$ in 2011-12.

- Spending per student has since fallen in real terms as cuts to public spending have gradually taken hold. Between 2011-12 and 2017-18, we estimate that spending per student fell by around $12 \%$ in real terms.

Beyond 2017-18, the government has committed to freeze the national per-pupil base rate in cash terms and has committed extra funds for the introduction of T levels. This amounts to about $£ 115$ million in 2019-20, but will grow to about $£ 445$ million by $2021-22$ (all figures at UK level). ${ }^{31}$ In total, this will amount to about an extra $£ 600$ per student in further education in 2021-22. However, these extra funds are relative to continuing realterms cuts in the core level of FE and sixth-form college funding. The new money for $T$ levels and the proposed cuts to the rest of the FE college budget offset each other almost exactly, so that spending per student will be largely held constant in real terms between 2017-18 and 2019-20. Furthermore, most of the extra money for T levels is focused on delivering extra teaching hours, so is unlikely to ease the resource challenges on the sector. We do not project the overall level of spending on further education up to 2021-22, as the overall settlement for further education is yet to be announced.

If delivered, these projections would leave spending per student in further education at around $£ 5,700$ per student in 2019-20. This is well above its low point in 1998-99, and about $£ 500$ or $10 \%$ higher than at the start of our series in $1989-90$.

However, spending in other areas of education has risen even more quickly. This means that spending per student in an FE or sixth-form college is now about $8 \%$ lower than spending per pupil in secondary school, having been about 50\% greater at the start of the 1990s. It may well be that spending on further education was relatively generous in the early 1990s. However, the change compared with secondary schools is clearly dramatic.

Trends in school sixth-form spending per student are only available back to 2002-03. We see from Figure 4.5 that annual spending per student was over $£ 600$ higher in school sixth forms than in further education colleges on average over the course of the 2000s. Both grew during the period, but faster growth in further education meant that the picture had reversed by 2011-12, and spending per student is now around $£ 700$ higher in further education than in school sixth forms. This largely results from a faster pace of cuts to school sixth-form spending per student, which has fallen by around $20 \%$ in real terms between 2011-12 and 2017-18 (compared with 12\% for further education).

Up to 2010, there was significant concern regarding the more generous funding of school sixth forms compared with further education colleges. The contrasting trends since then are a direct result of policymakers' efforts to ensure greater parity in funding between school sixth forms and further education colleges. As we shall see in the next section, the

31 Announced in Spring Budget 2017 (https://www.gov.uk/government/publications/spring-budget-2017documents). 
higher level of funding per student in further education colleges is also related to the different mix of pupils and type of qualifications undertaken.

It is also important to acknowledge that schools with sixth forms could have benefited from the real-terms protection to primary and secondary school spending per pupil under the coalition government (discussed in Chapter 3). These schools may have been able to partly offset cuts to sixth-form spending over that period. This is likely to have been less feasible since 2015-16, when school spending per pupil has also been cut in real terms.

Figure 4.6 shows spending per learner in apprenticeships (16-18 and 19+ shown separately) and 19+ further education between 2002-03 and 2016-17. Due to lack of data on hours of learning, these figures are per learner and not per full-time equivalent. As most of these courses start and finish at different points in time and vary in length, the figures shown do not represent the total cost per student on each form of study, which could last much longer than a year. ${ }^{32}$ However, the figures do give a useful indication as to how cuts in the adult education budget have been delivered

Unsurprisingly, we see that spending per learner is lower in 19+ further education and apprenticeships than in all forms of 16-18 education. Since adult learners are much more likely to study part-time than 16- to 18-year-olds, it is not surprising that the amount of funding per learner is lower for those aged 19 and older.

Figure 4.6. Spend per learner each year in apprenticeships and 19+ further education

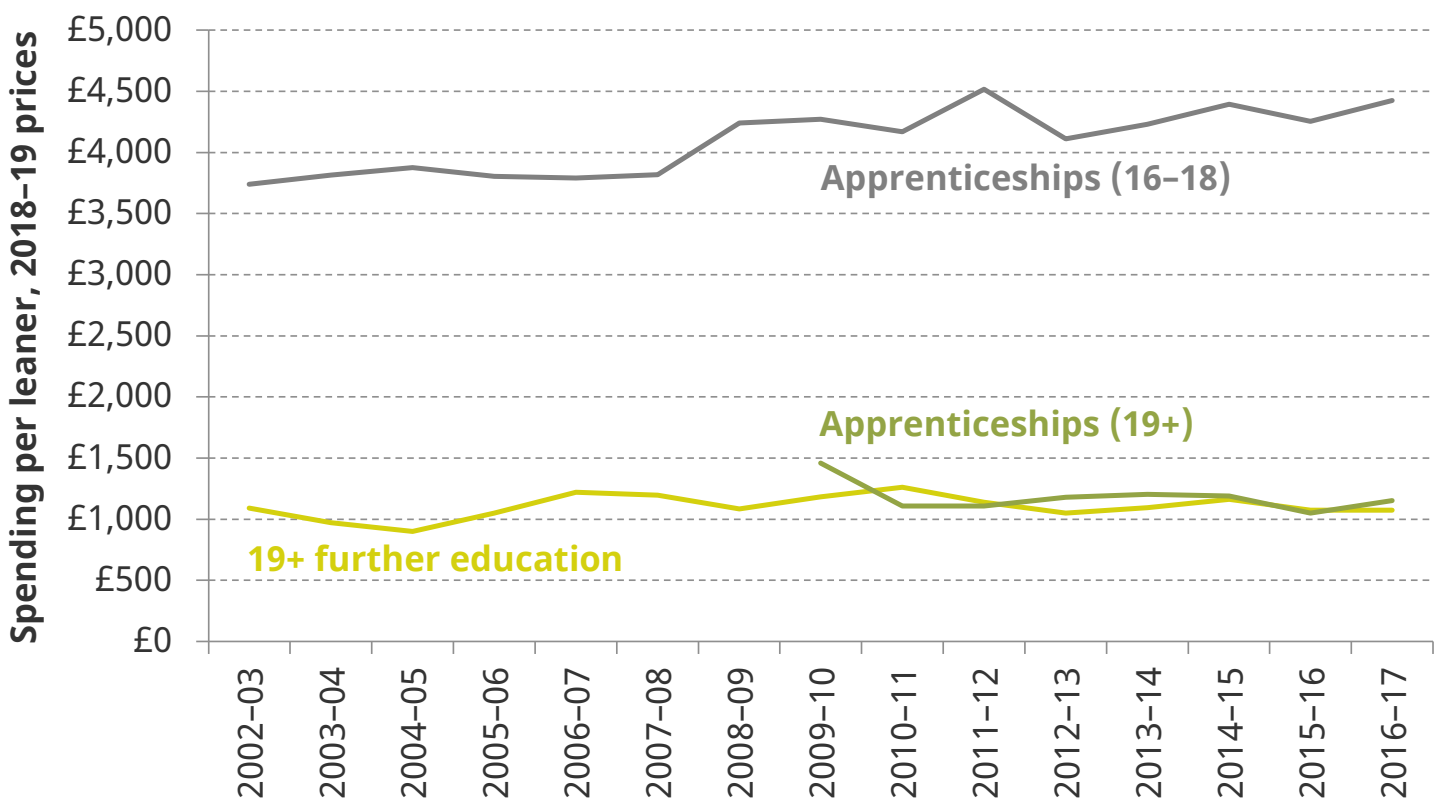

Note: All figures are per learner observed at any point during the financial year and not per full-time equivalent. Figures do not represent the total cost of each form of education, which may span multiple years.

Source: See Figure 4.4 for spending figures, Figures 4.1 and 4.3 for learner numbers (18-year-old apprentices included in addition).

32 The figures will also be affected by changes in enrolment patterns. For example, if a large group of apprentices starts near the end of the year, this would have relatively little impact on spending in that year but a larger effect on the total number of learners in that year. Taken together, this would reduce spending per learner in that year. 
Compared with the large changes in spending on 16-18 further education shown in Figure 4.5 , spending on adult learners in Figure 4.6 is relatively stable. In real terms, spending on $19+$ further education has been around $£ 1,000$ per learner each year since the early 2000 s. This strongly suggests that much of the fall in adult education spending over time has been driven by reduced numbers rather than by reduced spending per learner.

Spending per learner each year on 16-18 apprenticeships rose sharply - by around $£ 400$ between 2007-08 and 2008-09. Since then, it has risen gradually (albeit with year-to-year changes) to just over $£ 4,400$ per apprentice each year in 2016-17. This is clearly a lot higher than for 19+ apprenticeships and may reflect larger amounts of off-the-job or classroom training. It is also only $£ 1,300$ lower than spending per full-time equivalent in 16-18 further education. As a result, unless such classroom or off-the job training takes up more than $75 \%$ of $16-18$ apprenticeships, spending on education or training in 16-18 apprenticeships is higher than in further education each year.

\subsection{Role of funding systems}

Funding for further education in England is allocated through three different funding systems, which each have very different roles for students, learning institutions and government.

- Funding for 16- to 19-year-olds is covered by the 16-19 Funding Formula. This formula covers technical and vocational qualifications for students in this age range as well as academic qualifications such as $\mathrm{A}$ levels.

- Funding for adult education (aged 19 and older) comes from the adult education budget. The funding formula for this supports adult students undertaking eligible qualifications. Unlike the 16-19 system, not all students and courses are eligible for support; Table 4.2 gives a more detailed overview of where this system applies.

- Adult students taking a more advanced qualification that is not eligible for funding under the adult education budget are able to take out advanced learner loans. These are designed to mimic the student loans available for students in higher education: rather than making fixed repayments like a mortgage, the amount that students pay back depends on their income after graduating.

- From May 2017, apprenticeships are funded from the new Apprenticeship Levy and funding system. Employers pay a levy of $0.5 \%$ on payroll expenditure above $£ 3$ million, which is transferred into a digital account and can then be used to pay for the off-thejob training costs of apprentices. Other expenditure on off-the-job training for apprentices (by levy- and non-levy-paying employers) is subsidised by $90 \%$ from public funds (up to a maximum limit).

Table 4.2 provides further detail on where the first three systems apply. In the rest of this section, we describe how all four systems work: where they apply, how they allocate funds, and the incentives that this creates for students, government and FE providers. 
Table 4.2. Applicability of further education funding systems

\begin{tabular}{|c|c|c|c|c|c|c|}
\hline & \multirow{2}{*}{$\begin{array}{c}\text { First } \\
\text { English or } \\
\text { maths } \\
\text { GCSE }\end{array}$} & \multicolumn{2}{|c|}{ Level 2} & \multicolumn{2}{|c|}{ Level 3} & \multirow[t]{2}{*}{ Level 4-6 } \\
\hline & & First & Subsequent & First & Subsequent & \\
\hline $16-19$ & 16-19FF & $16-19 F F$ & 16-19FF & 16-19FF & 16-19FF & 16-19FF \\
\hline $\begin{array}{l}\text { 20-24, } \\
\text { EHC plan }\end{array}$ & 16-19FF & $16-19 F F$ & 16-19FF & 16-19FF & 16-19FF & 16-19FF \\
\hline $\begin{array}{l}\text { 19-23, } \\
\text { unemployed }\end{array}$ & AEB & AEB & AEB & AEB & ALL & ALL \\
\hline $\begin{array}{l}\text { 19-23, } \\
\text { other }\end{array}$ & AEB & AEB & $\begin{array}{c}\text { AEB } \\
\text { co-fund }\end{array}$ & AEB & ALL & ALL \\
\hline $\begin{array}{l}\text { 24+, } \\
\text { unemployed }\end{array}$ & AEB & AEB & AEB & ALL & ALL & ALL \\
\hline $\begin{array}{l}24+, \\
\text { other }\end{array}$ & AEB & $\begin{array}{c}\text { AEB } \\
\text { co-fund }\end{array}$ & $\begin{array}{c}\text { AEB } \\
\text { co-fund }\end{array}$ & ALL & ALL & ALL \\
\hline
\end{tabular}

Abbreviations: 'EHC plan' = Education, Health and Care plan. '16-19FF' = 16-19 Funding Formula. 'AEB' = adult education budget funding formula. 'ALL' = advanced learner loans.

Note: 'First' qualifications refer to the first full qualification.

\section{Describing the systems}

Unlike schools or higher education, the FE sector has several funding formulas that allocate money in quite different ways. Table 4.3 provides an overview of each of the systems and where they do - or do not - coincide.

As Section 4.1 describes, the FE sector serves a diverse set of learners. Students aged 16 and 17 are now largely enrolled in full-time education, while adult learners are much more likely to study part-time. The FE funding system further distinguishes between young people studying certain types of qualifications - primarily at Level 2 and 3, equivalent to GCSEs and A levels - and older adults who are returning to education.

In practice, this means that there are very different sets of principles underpinning each of the funding systems. In keeping with the legal requirement that 16- to 18-year-olds are enrolled in education or training, the 16-19 Funding Formula functions in a similar way to the National Funding Formula for schools. Qualifications are delivered at no cost to the student, and institutions are reimbursed based on a central government estimate of how expensive they ought to be to provide.

By contrast, the advanced learner loan (ALL) system reflects the approach taken in the higher education system, where students are treated as consumers who pay tuition fees to finance their education. The government provides up-front financing to students through a system of loans, and as students repay these loans they are effectively taxed on part of the value (in the form of higher earnings) that they have received from their qualification. Of course, these loans are much more generous than a regular loan from the bank; students who have lower earnings pay back less (or none) of their loan, so the 
Table 4.3. Overview of the elements of the further education funding formulas

\begin{tabular}{|c|c|c|c|}
\hline & $16-19 \mathrm{FF}$ & AEB & ALL \\
\hline Unit of funding & Banded hours & Banded hours & Course fee \\
\hline Area cost factor? & Up to $20 \%$ & Up to $20 \%$ & \\
\hline Area disadvantage? & $8-34 \%$ & $8-34 \%$ & \\
\hline Student disadvantage? & $\begin{array}{c}\text { Care leaver } \\
\text { No GCSE maths } \\
\text { No GCSE English }\end{array}$ & & 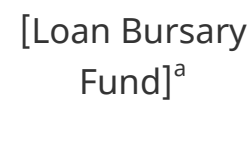 \\
\hline Subject uplift? & Up to $75 \%$ & Up to $72 \%$ & \\
\hline Large programme uplift? & Up to $20 \%$ & $\begin{array}{c}\text { Some qualifications } \\
\text { have set funding }\end{array}$ & \\
\hline Retention factor? & $\begin{array}{l}50 \% \text { penalty } \\
\text { for dropouts }\end{array}$ & $\begin{array}{l}\text { Monthly payments; } \\
20 \% \text { at completion }\end{array}$ & \\
\hline Student contribution? & & $\begin{array}{l}50 \% \text { co-funding in } \\
\text { some cases }\end{array}$ & $\begin{array}{l}\text { Income-linked } \\
\text { repayments }\end{array}$ \\
\hline
\end{tabular}

${ }^{a}$ The ALL Loan Bursary Fund is funded by central government to support vulnerable and disadvantaged loan recipients. It is administered by individual institutions, which set their own criteria for eligibility.

government provides substantial insurance to people who do not benefit as much in the labour market from their qualification. ALLs are also written off for students who go on to and complete a higher education course, which reduces the student debt held by these graduates.

The adult education budget (AEB) is more closely aligned with the 16-19 Funding Formula, but with the important difference that some learners - primarily those aged 24 or older who are in work or not seeking a job ${ }^{33}$ - are expected to co-fund their qualifications. These students pay $50 \%$ of the agreed rate for their course. However, the 'agreed rate' in this case is still centrally set by the government based on the number of learning hours in the course, which are in turn regulated by the Office of Qualifications and Examinations Regulation (Ofqual). This means that AEB students are asked to pay for some of the cost of their qualification, but have limited ability to search out institutions that offer the programme more cheaply, since the funding rate is mainly determined directly by government policy.

In addition, AEB students who co-fund their qualification do not have access to the insurance against low earnings offered by the ALL programme: under the AEB system, students pay up front, and the contribution expected of them does not take into account their earnings either before or after they earn their qualification.

33 In 2018-19, the government is running a new trial that extends full funding to some learners who are employed but with low earnings. 


\section{6-19 Funding Formula}

Education for students between the ages of 16 and 19 is primarily funded through the 1619 Funding Formula. ${ }^{34}$ The national formula allocates a budget to each institution, which includes sixth-form colleges, schools and academies; further education colleges; and other specialised institutions such as independent learning providers..$^{35}$

The funding formula calculates the budget that each institution will receive based on the number of 'planned hours' its students are expected to receive in a year, adjusted for characteristics of the student body and the institution that might affect how costly it is to provide these hours. ${ }^{36}$ Planned hours are agreed by the student and the institution at the start of the year, in some cases subject to regulations by Ofqual. They include both learning time and scheduled 'non-qualification' hours for activities such as pastoral support or employability training.

Full-time students receiving more than 540 hours of learning time attract basic funding of $£ 4,000$ (though funding for 18 -year-olds who do not have high needs is capped at $£ 3,300$ for 450 hours of learning or more). For students who receive 280 or fewer hours of instruction, funding is adjusted as a share of the full-time rate (so a student studying for

\section{Figure 4.7. Base rate of funding per hour by total course length under the 16-19} Funding Formula and the adult education budget formula

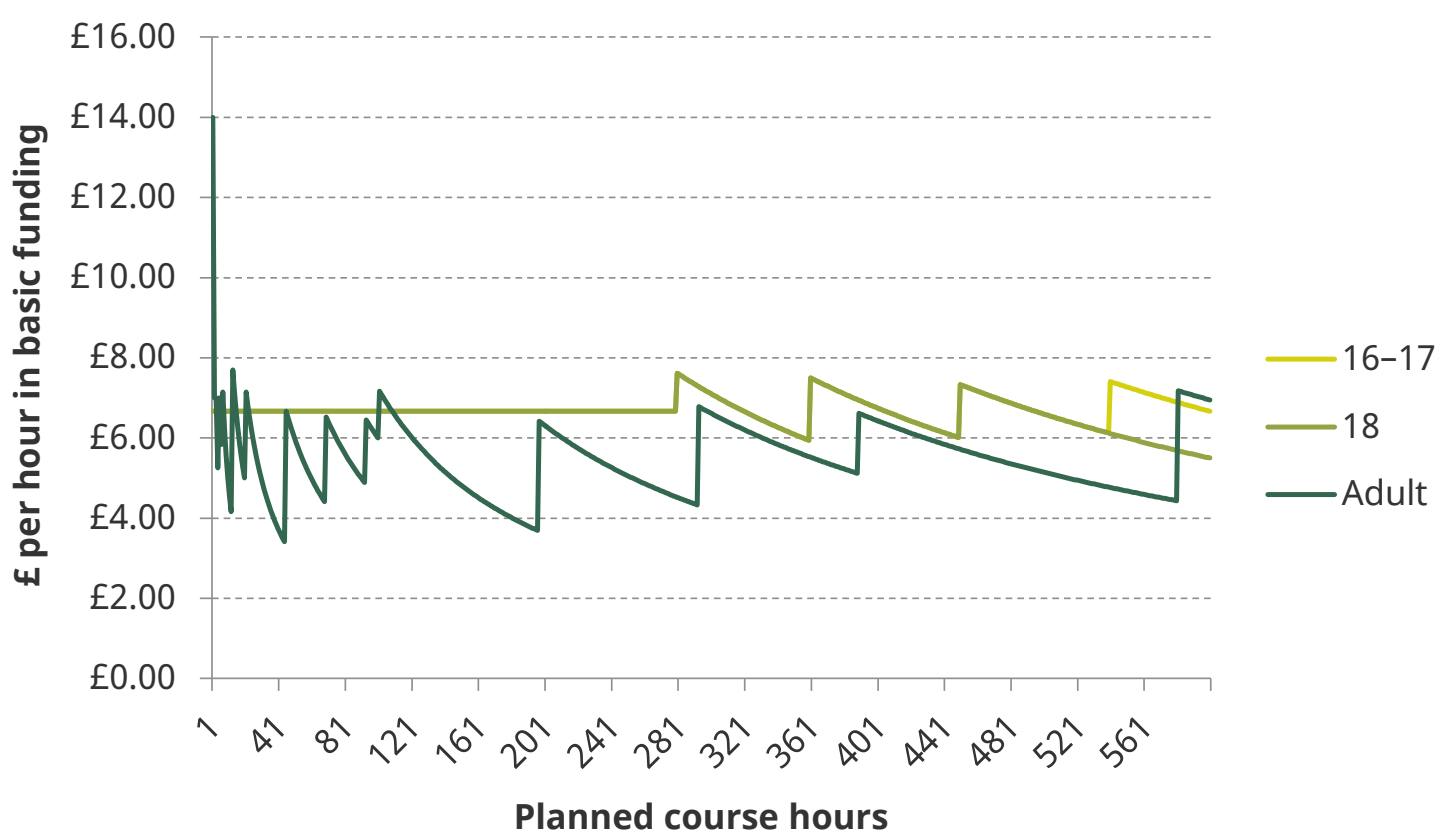

Note: Hourly funding rates are calculated by dividing the base rate of funding by the number of planned hours for the course. The funding systems for ages 16-17 and age 18 are the same for all courses of less than 540 hours, at which point there is an additional funding band for 16- and 17-year-olds.

${ }^{34}$ Courses at Level 4 and up - more advanced than A Levels - are primarily funded through the higher education student loan system discussed in Chapter 5. 19-year-olds are covered by this formula if they turned 19 during the qualification.

35 The formula also covers students aged 14-16 who are enrolled in FE institutions, and students with an Education, Health and Care (EHC) plan up to age 25.

36 Because the full set of relevant data - including information on dropouts - is not available at the start of the academic year, institutions are funded based on the characteristics of their previous cohort of students. 
$25 \%$ as many hours as a full-time qualification will attract $25 \%$ as much funding). These funding levels have been frozen in cash terms since 2013-14, which means that they are now around 6\% less generous; this is reflected in the falls in 16-18 FE spending reported in Section 4.2. In between these hours thresholds, the level of funding is not adjusted according to the proportion of full-time hours that a student is taking. Instead, funding increases in bands; within each band, institutions receive the same total amount of funding regardless of how many teaching hours the student receives. As Figure 4.7 illustrates, this means that the funding received per hour falls within each band, as the same amount of funding is divided by more hours.

In addition to the basic rate of funding based on hours, the funding formula also incorporates a range of adjustments to recognise additional costs and provide incentives and resources to support students (summarised in Table 4.3 and discussed in more detail below).

The formula adjusts the basic rate of funding based on planned learning hours so that institutions receive more money when they deliver 'costlier' vocational programmes (such as engineering or agriculture). These adjustments can be significant: specialist programmes attract a $75 \%$ uplift on their core funding. The formula also tries to incentivise institutions to support students to complete their qualification by withholding $50 \%$ of the funding for students who drop out.

Some programmes, such as the International Baccalaureate or a set of four A-level courses, involve much more than 600 hours of instruction in a year. To compensate institutions for offering these 'more than full-time' programmes, the funding formula allows for a $10 \%$ or $20 \%$ uplift of funding. This uplifted funding is not adjusted for programme cost or retention.

Institutions with disadvantaged student bodies also receive additional funding to help them support these students. First, they receive an extra $£ 480$ for each pupil who is a foster care leaver, or who does not hold the equivalent of a good GCSE in English, or who does not hold the equivalent of a good GCSE in maths. They also receive additional funding for students who come from disadvantaged neighbourhoods, with up to $34 \%$ more funding for students from the most disadvantaged areas.

This entire package of funding - based on student learning hours, programme cost, retention, large programme funding and disadvantage - is then scaled up by an area cost factor, to reflect the higher cost pressures in some parts of the country. The intent of the area cost uplift is to ensure that providers in expensive areas such as London have similar purchasing power for costs (e.g. for staff and facilities) to institutions elsewhere.

In order to arrive at the final budget for institutions, the level of programme funding is adjusted based on two additional considerations. Some institutions have their budget boosted under the transitional Formula Protection Funding arrangement, which limits the amount of funding that institutions can lose as a result of the 2013-14 reforms. This transitional protection is being phased out, with the last payments due in 2020-21. Institutions can also lose funding if their students do not meet the 'maths and English condition of funding'. This requires students who have not yet achieved GCSEs in these subjects at grades 9-4 ( $A^{*}-C$ under the old grading system) to continue to study towards these qualifications as part of their post-16 learning. 


\section{Adult education budget}

The adult education budget for students aged 19 and up provides funding for eligible students to take eligible qualifications. Students are fully funded to study towards the equivalent of a good GCSE in English and/or maths if they have not yet achieved these qualifications. Students aged 19-23 are also fully funded for their first Level 2 and Level 3 qualifications.

For those aged 24 and older, the AEB fully funds Level 2 qualifications only for those who are unemployed and actively seeking work. Most full-time students would not meet this definition, because people in full-time education are not eligible for jobseeker's allowance - one of the main benefits used to determine who counts as 'unemployed'. For students who are either in work or not actively seeking a job, the government pays $50 \%$ of the cost and the student is responsible for the remainder. ${ }^{37}$

As Table 4.3 illustrates, there are substantial similarities between the components of the AEB and the 16-19 Funding Formula. Both formulas allocate resources to institutions based on the number of instructional hours they provide to their students, and both offer uplifts for area cost, area disadvantage and subject area. However, unlike the 16-19 Funding Formula, institutions do not receive extra funding based on the individual circumstances of their students (i.e. care leavers or without GCSE-level qualifications in maths or English).

Like the 16-19 Funding Formula, the AEB formula is based on banded hours, with funding per hour falling in each band. However, as Figure 4.7 shows, the funding thresholds in the AEB are very different from those in the 16-19 formula. The funding levels set at each threshold also make for very large differences in hourly funding for courses that are almost the same length: for example, an institution offering a course that lasts 196 hours receives $£ 724$ in basic funding per student ( $£ 3.69$ per hour of instruction). Making the course just one hour longer means that basic funding jumps up to $£ 1,265$ and funding per hour increases by almost $75 \%$ to $£ 6.42$.

Compared with a system where funding is calculated per hour of learning time (perhaps with an additional fixed amount of funding per student and some overall cap on funding for full-time students), this banded system creates very strong financial incentives for institutions to manipulate the learning hours they offer.

The huge jumps in hourly funding for courses that are very similar lengths are unlikely to reflect real costs to providers. On top of that, there is little reason to think that the funding thresholds chosen and the pattern of funding per hour that they imply should be so dramatically different for students who are younger or older than 19.

The AEB also takes a different approach to incentivising institutions to retain students: rather than paying providers based on the previous year's student numbers with a $50 \%$ reduction in funding for any dropouts, the AEB funds institutions in monthly instalments, with $20 \%$ of the funding withheld until the student has completed the qualification.

37 The co-funding requirement applies only to the 'unweighted rate' for the programme, which is based on the number of learning hours; the government pays all costs associated with the disadvantage and area cost uplifts, as well as additional costs related to the subject area. This is due to a policy decision that 'a learner should not be expected to contribute more for the same size of the learning aim [qualification] just because that learning aim is more costly to deliver' (Skills Funding Agency, 2017, para. 23). 


\section{Advanced learner loans}

Students aged at least 19 taking a qualification at Levels 3-6 who are not entitled to support through the adult education budget have the option of taking out advanced learner loans to fund their studies. Unlike the 16-19 and adult education funding formulas, where the government funds (or co-funds) the provision of training, these loans are intended to support students in covering the cost of their own qualifications while providing (substantial) insurance against the risk of low earnings. They are analogous to the student loans provided for higher education (and discussed in greater detail in Chapter 5).

Advanced learner loans do not operate like regular loans from a high-street bank, where the borrower has to pass a credit check and repay a fixed amount each month or year. Instead, they are income-contingent, meaning that the amount a student repays each month is linked to how much they earn. Any remaining balance is written off after 30 years. ${ }^{38}$

As we discuss in Chapter 5, the link between income and repayments provides substantial insurance for students: those who go on to have low earnings will not be saddled with large loan repayments, while those with higher incomes will pay a greater part of the cost of their qualification.

However, if low-earning students do not repay their loans, that means the government is left covering the debt. This means that the income-contingent system also introduces a large, if hidden, government subsidy to education.

\section{Comparing advanced learner loans and the HE student loan system}

The loans offered under the ALL system are identical to the HE student loans: the repayment threshold of $£ 25,000$ is the same in both systems, as are the repayment rate (9\%), interest rates (RPI inflation plus between 0 and 3\%) and the write-off periods (30 years from graduation). HE students are also eligible for maintenance loans, which are not available to those studying for FE qualifications.

However, graduates with FE and HE qualifications are very different in other ways. On average, those who graduate with an FE qualification are older ${ }^{39}$ and, as discussed in Section 4.1, had lower school grades than HE graduates. They also have, on average, lower earnings. ${ }^{40}$

38 In addition, advanced learner loans for Access to HE courses are written off when the student completes an HE qualification.

39 The median age of UK graduates from Level 3 vocational programmes is 25 (OECD, 2018), excluding those who graduate before age 19 as they would not be eligible for ALL. The median age of graduates from undergraduate HE programmes cannot be precisely determined from publicly available data, but two-thirds of first-year undergraduate students are aged 20 and under (Higher Education Statistics Agency, 2018). Since the majority of students study full-time and typically graduate within four years, the median HE graduate will be younger.

40 Median earnings for HE graduates one year after graduation were $£ 16,600$ (Department for Education, 2017a, table 1). For FE graduates on skills courses (rather than apprenticeships, which do not fall under the ALL system), median earnings were approximately $£ 14,900$ one year after completing a qualification (Department for Education, 2017b, earnings table 5a). Both figures draw on tax data from the 2014-15 tax year. 
Table 4.4. Student loan repayments for 2016 graduation cohort

\begin{tabular}{l|c|c}
\hline & Advanced learner loans & HE student loans \\
\hline Fully repaid & $2.7 \%$ & $2.3 \%$ \\
Made repayment & $17.5 \%$ & $38.1 \%$ \\
Below threshold & $45.2 \%$ & $36.3 \%$ \\
Not in work & $3.1 \%$ & $6.2 \%$ \\
Loan cancelled & $5.7 \%$ & $0.2 \%$ \\
Other & $25.7 \%$ & $16.9 \%$ \\
\hline Total borrowers & 117,248 & 475,521 \\
\hline
\end{tabular}

Note: 'Other' category includes awaiting first year's tax return, status that does not require repayment, and overseas residents who have defaulted, whose payment status is unknown, or who have not provided income details.

Source: Tables 3A (i)-(iv) of Student Loans Company, 'Debt and repayment statistics for England', https://www.slc.co.uk/official-statistics/student-loans-debt-and-repayment/england.aspx.

These factors affect the likely repayments of ALL and HE student loans. Table 4.4 compares the repayments of ALL and HE student loans for the 2016 graduating cohort in their first year in the labour market. Unsurprisingly, very few graduates have fully repaid their loans at this point. But HE graduates are more than twice as likely to have made some repayment on their loan, while nearly half of FE graduates earn below the repayment threshold, compared with just over a third of HE graduates. This is particularly noteworthy since FE graduates are typically older and therefore less likely to be just starting out in the workforce on lower wages. This suggests that a greater proportion of FE graduates' earnings will be below the repayment threshold, so FE graduates will repay a smaller share of their income. ${ }^{41}$

This does not necessarily mean that the government will subsidise FE students more heavily by writing off a greater proportion of their loans. Advanced learner loans are much smaller than HE student loans - the average FE student who borrowed and became eligible to repay in 2018 owed $£ 2,890$, compared with the average HE student, who owed $£ 34,800$ when becoming eligible to repay that year (Student Loans Company, 2018). So even if an FE graduate pays a smaller amount each year, they might still finish repaying earlier than someone who graduates from HE at the same time.

When designing these loan systems, the government needs to consider not only the relative cost borne by the graduate and the taxpayer, but also how the system influences people's choices. There are several goals to keep in mind when designing an incomecontingent student loans system. The system should tax the 'value added' of the qualification (the earnings a person has over and above the counterfactual of what they would have earned without the qualification). The system can also provide insurance against low earnings, and will ideally be easy to administer. Finally, a student loans system should not unintentionally influence people's decisions.

${ }^{41}$ Because they are older, FE graduates are also more likely to retire before their loans are written off after 30 years. Since income typically falls in retirement, this can also impact their loan repayments. 
Based on these goals, policymakers can consider whether the FE and HE loan systems should look as similar as they do. To the extent that FE graduates have lower counterfactual earnings than HE graduates, taxing the 'value added' by a course implies a lower repayment threshold for FE student loans. However, to the extent that the same person is choosing between $\mathrm{FE}$ and $\mathrm{HE}$, offering different thresholds in each system could influence their decision.

It is also important to stress that the total size of the advanced learner loans sector is dwarfed by the HE student loans system. In the 2016 cohort, there were around four times as many HE student loans issued as advanced learner loans. But because of the differences in average loan size, the total value of new HE loans is around 40 times as high, as shown by Figure 4.8. Adding in support for HE students through maintenance loans (which are not available to FE students), new HE loans were worth 65 times as much as new ALLs. ${ }^{42}$

Finally, while the ALL system is clearly very similar to the HE student loans system in how it structures repayments, there are important differences in the scope of the two systems. For the moment, FE learners are not eligible for the maintenance loans that are available in the HE sector. These loans are intended to support disadvantaged students by covering their living costs while they are studying rather than working. Without these loans on offer, students who give up work or reduce their hours to study for an FE qualification will need to look to other sources - e.g. personal savings or high-street loans - to cover these costs.

Figure 4.8. Value of new loans, by education sector and academic year

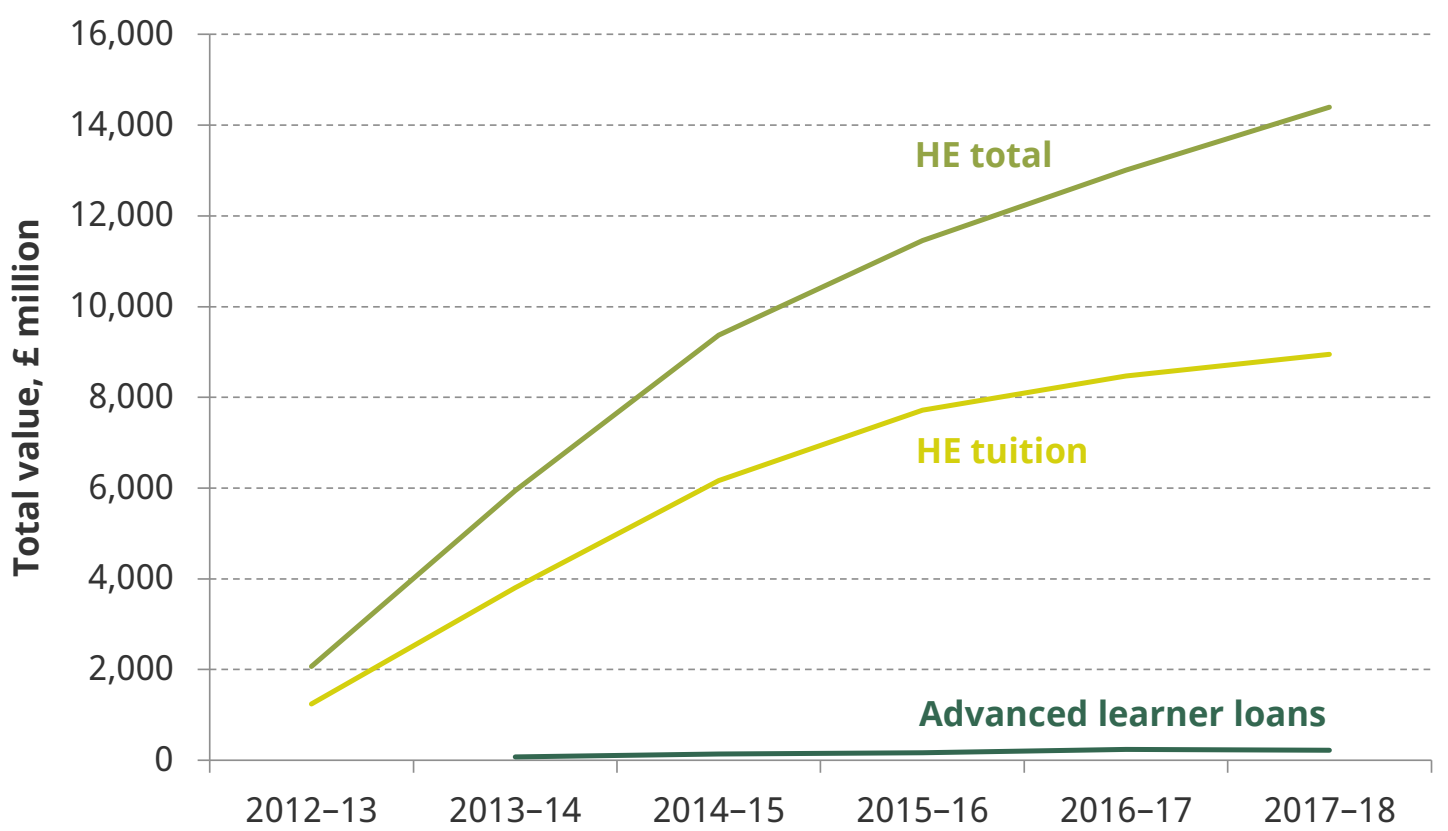

Note: 'HE total' includes both tuition and maintenance loans for HE students.

Source: Tables 1A and 1B of Student Loans Company, 'Debt and repayment statistics for England', https://www.slc.co.uk/official-statistics/student-loans-debt-and-repayment/england.aspx.

42 The actual amount paid out in ALLs is consistently lower than the amount budgeted, sometimes dramatically so; in 2015-16, for example, only around a third of the ALL budget allocation was paid out (Foster, 2018). 
There is also a lifetime cap of four advanced learner loans per person. This cap will help to support the public finances by limiting the amount of ALL debt that students take on, and therefore limiting the potential liability to the government from those who cannot repay. However, a cap on the number of courses - rather than loan amounts - creates an incentive for students to 'save' their loans for the longest and most expensive courses they wish to take. In particular, this could lead to students choosing not to use ALL to fund a short course today, since there is a possibility that they will need or want to study for a more expensive qualification at some point in the future.

\section{Apprenticeship Levy and funding ${ }^{43}$}

The new Apprenticeship Levy was introduced in England in April 2017. It requires all employers in England to pay a $0.5 \%$ levy on their total paybill (all their wage costs) in excess of $£ 3$ million. The $£ 3$ million threshold means that only $2 \%$ of employers will pay the levy, but at least $60 \%$ of employees are likely to be working for an employer paying the levy (Amin-Smith, Cribb and Sibieta, 2017). The Apprenticeship Levy is a payroll tax similar to employer National Insurance contributions, although the levy is based on the total payroll of an organisation rather than each individual's own earnings. The Office for Budget Responsibility (2018) forecasts that the Apprenticeship Levy will raise $£ 2.7$ billion by $2019-20$.

All employers in England who pay the levy, including public sector employers, have their levy payments put into a 'digital account', which they can then spend on off-the-job training of apprentices. This amount is topped up a further $10 \%$ by the government. These funds will expire after 24 months if unspent but, barring this detail, the 'digital account' essentially amounts to levy-paying employers being offered a full government subsidy for apprenticeship training costs up to the value of $110 \%$ of each employer's levy amount. Levy-paying employers pay $10 \%$ of the cost of any spending over and above what is in their digital account, with the taxpayer footing the other $90 \%$ of the cost (up to a cap, set out below).

Employers who do not pay the levy receive a $90 \%$ subsidy towards the training costs of apprentices. Small employers with fewer than 50 employees are fully funded for the training costs of apprentices aged $16-18$, again up to the cap.

Government funding is restricted to a limit per apprentice.$^{44}$ Each apprenticeship framework or standard is assigned to one of 30 funding bands (up from 15 funding bands in May 2017) decided upon by the new Institute for Apprenticeships, each with an upper limit of between $£ 1,500$ and $£ 27,000$ to cover the full duration of the apprenticeship. Allocation to a particular band is supposed to reflect the expected costs of training for each apprenticeship. The government only funds the training costs for apprentices who are training at a higher qualification level than they currently possess. This means that, while graduates holding an undergraduate degree (a Level 5 qualification) can receive public funding as an apprentice, they must be undertaking a Level 6 (equivalent to a masters degree) apprenticeship or higher.

43 For more details, see Department for Education (2018d).

44 In addition, the government will give both employer and training provider a $£ 1,000$ grant for training an apprentice aged 16-18 or an apprentice aged 19-24 if they have previously been in care or have an Education and Health Care plan. 
Under this system, the link between payments into the levy system and the public subsidy received by individual employers is relatively weak. Employers who do not pay the levy at all will still be eligible for a subsidy of $90 \%$ of the upper funding limit, while spending by employers who do pay the levy will be subsidised either $100 \%$ or $90 \%$, with the levy amount only providing the threshold for the slight drop in subsidy rate.

As a result, the upper limits set by the Institute for Apprenticeships are of far greater importance for determining likely public subsidies for apprenticeships than the amounts raised by the levy. Furthermore, most of the increase in revenue will not be used to fund apprenticeships. In England, apprenticeship funding is set to increase by $£ 640$ million in cash terms between 2016-17 and 2019-20. This compares with a total of $£ 2.7$ billion that is expected to be raised by the levy in 2019-20.

There are currently over 330 apprenticeship standards with upper funding limits listed as available for delivery from August $2018^{45}$ (these are in addition to the old system of apprenticeship frameworks, many of which continue to be available for delivery). Amongst Level 2 apprenticeships, they include $£ 3,000$ for an adult care worker, $£ 4,000$ for a junior estate agent and $£ 12,000$ for a forest operative. Amongst Level 3 apprenticeships, they include $£ 5,000$ for a teaching assistant, $£ 12,000$ for a digital marketer and $£ 18,000$ for a bus and coach engineering technician. Amongst Level 4 apprenticeships, they include $£ 15,000$ for a data analyst, $£ 18,000$ for a software tester and $£ 27,000$ for a nuclear welding inspection technician. In addition, there are a range of degree-level apprenticeship standards, which tend to attract funding limits closer to the maximum, such as solicitor $(£ 27,000)$ and relationship manager (banking) and aerospace engineer $(£ 27,000)$, as well as a range of public service occupations such as nursing $(£ 27,000)$ and police constable $(£ 24,000)$.

The wide range of apprenticeship standards creates a number of concerns and challenges. First, many of the new standards are highly specific and it is not clear whether they will be of economic value outside the occupation they apply to. This may make people completing these apprenticeships vulnerable to economic changes. Second, it is not clear whether the market for off-the-job training is sufficiently well developed to ensure highquality training for the vast range of apprenticeship standards being developed. Ofsted is now responsible for inspecting and assessing the quality of apprenticeship training, but it will face obvious challenges in regulating a sector where the numbers of standards and training providers have increased so quickly.

\subsection{Future reforms and challenges}

The further education sector faces a range of complex challenges over the coming years. Here, we confine ourselves to discussing the challenges related to resources.

First, the cuts to spending per pupil since 2010 clearly place significant pressure on providers, with a cut of $8 \%$ in further education spending per pupil aged $16-18$ and a cut of more than $20 \%$ in school sixth-form spending per pupil. Although the latter was coming from a higher base and was predictable from the funding system, spending per pupil in school sixth forms is now significantly lower than spending per student in further

\footnotetext{
45 https://www.gov.uk/government/publications/apprenticeship-funding-bands.
} 
education colleges and lower than spending per pupil aged 11-16 in secondary schools. The main challenge is therefore seeking to deliver a high-quality and varied curriculum on a continually declining budget.

Second, the sector is preparing for responsibility for the adult education budget to be devolved to the Greater London Authority and the mayoral combined authorities in 2019$20 .{ }^{46}$ This is a potential opportunity for local areas to take on a larger role in equipping their workforce with the skills needed by their local economy. However, to date, there has been relatively little information on how this will work in practice. Further, devolution will not cover all elements of post-18 funding: for example, apprenticeships will continue to be funded and managed centrally, though some areas are pushing for more control over this. Ensuring that these different training systems remain complementary and easy for students to navigate will be an important challenge for the new mayoral authorities to take on.

Third, the role of $\mathrm{T}$ levels represents a significant challenge for the further education sector in particular. These new qualifications will seek to simplify the choices available to young people into 15 different lines of learning, raise the prestige of vocational qualifications and increase classroom learning time. These are laudable aims. However, they are coming on a very tight timetable: T levels are due to be rolled out by 2020 . This will be particularly challenging since the government intends to use a single awarding organisation for each T level, which has been a source of significant controversy. ${ }^{47}$ Reflecting concerns about the feasibility of this timeline, the Permanent Secretary of the Department for Education sought a written direction from the Secretary of State to press ahead with these plans. There must therefore be significant concerns as to whether highquality $T$ levels will be ready from day one.

Finally, much of the direction of further education reform has been towards equipping young people and adults with quite specific occupational skills, potentially at the cost of more general skills. T levels will be specific to particular occupations, whilst adult education has become much more sharply focused on apprenticeships. There is clearly a lot of uncertainty about the level of labour demand in particular industries and occupations, and how this will change when the UK leaves the European Union. It is not clear whether focusing on specific occupational skills is the best response to such uncertainty as it might lead to the need for large elements of retraining as different economic and trade shocks change demand in different industries over time. It would also be relatively simple to include general skills transferable across occupations in both $T$ levels and apprenticeships. Doing so might make individuals taking such qualifications less vulnerable to negative economic shocks.

\footnotetext{
46 For more details, see Department for Education (2018c).

47 See https://feweek.co.uk/2018/05/29/dfe-begins-t-level-tender-process-for-single-awarding-organisations/.
} 


\section{Higher education}

Under the current higher education (HE) funding system in England, it costs around $£ 17$ billion to fund the education of each cohort of undergraduate students. This includes the cost of teaching for three or more years and funding towards the cost of living while at university for more than 350,000 students. Initially, this cost is funded entirely from government finances. ${ }^{48}$ In the long run, however, graduates make repayments on their student loans and the cost is split between taxpayers and students.

The HE system is funded primarily through tuition fees, with some government grants for 'high-cost' subjects. However, few students have to pay these fees up front. Most students can take out government-backed loans to cover the full cost of tuition fees and contribute towards the cost of living (to do so, they must be UK domiciled and taking their first undergraduate degree). These loans are repaid on an income-contingent basis; graduates repay a proportion of their income over a certain threshold and any outstanding loan is written off at the end of the repayment period. This system ensures that students do not face an up-front cost of attending $\mathrm{HE}$, high-earning graduates contribute towards the cost of their degrees and there is insurance for graduates who have periods of low earnings.

This has not always been the case. In the 1990s, the provision of HE was entirely funded through direct teaching grants paid to universities by government; graduates did not contribute toward the cost of their degrees. Sequential reforms in 1998, 2006 and 2012 introduced and increased tuition fees. These reforms, alongside the relaxation of controls on the number of students that universities could accept, have served to create a quasimarket structure in the HE system where universities are incentivised to compete to attract new students.

In what follows, Section 5.1 sets out how recent reforms have affected the overall level of funding universities receive for teaching, Section 5.2 shows the impact on the government finances and Section 5.3 sets out the changes in graduate contributions over time. Finally, Section 5.4 describes the impacts of potential future reforms and Section 5.5 discusses the challenges facing the sector in the coming years.

\subsection{University resources}

For each student who started HE in 2017-18, universities receive an average of $£ 28,200$ (2018-19 prices) to fund the teaching of their degrees, as shown in Figure 5.1. This is $17 \%$ more in real terms per student than the funding level for the cohort who started in 199091.

However, the growth over this period has been far from smooth. Between 1990-91 and 1997-98, growth in student numbers significantly outpaced increases in teaching grants, resulting in a $25 \%$ real-terms decline in university funding per student. Since 1997-98, teaching resources per student have grown by $56 \%$. This has largely been the result of sequential tuition fee reforms.

\footnotetext{
48 This figure excludes the cost of tuition fees paid directly by students not taking out loans.
} 


\section{Figure 5.1. Total teaching resources provided per student in HE for cohorts starting between 1990-91 and 2017-18 (2018-19 prices)}

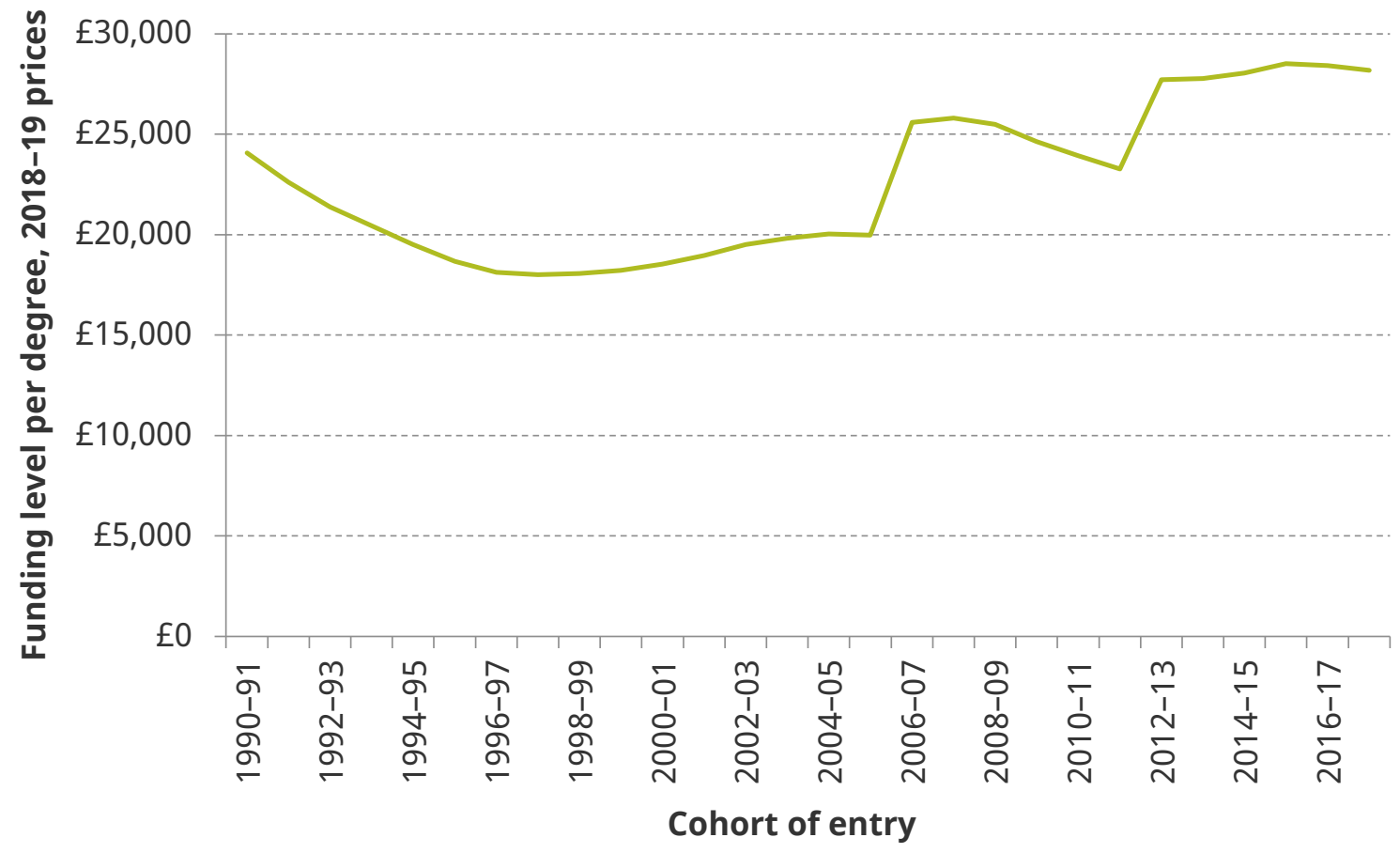

Note: The total level of teaching resources per degree is the sum of teaching grants, fees paid by local authorities (prior to their removal from 1998-99) and the up-front fees paid by students (with or without student loans). The up-front fees included in total resources prior to 2012-13 assume all courses are three years, so they represent a slight underestimate. The fee loan subsidy and teaching grants from 2012-13 onwards account for the actual course length. Fee waivers are included in the deficit impact for 1998-99 to 2005-06; total resources then include the additional income from fees. For 2006-07 to 2017-18, institution-specific bursaries and fee waivers (when appropriate) are deducted from total resources. For 2012-13 to 2014-15, National Scholarship Programme funding is included in total resources.

Source: HEFCE Teaching Grant Letters, various years (http://www.hefce.ac.uk/funding/annallocns/). Figures from Department for Children, Schools and Families (2008). Data on student numbers are from HESA statistics (https://www.hesa.ac.uk/) and the 'Historical statistics on the funding and development of the UK university system' data available through the UK Data Archive (http://www.data-archive.ac.uk/). HM Treasury deflators, March 2018 (https://www.gov.uk/government/statistics/gdp-deflators-at-market-prices-and-money-gdp-march2018-quarterly-national-accounts).

In 1998, tuition fees were introduced at $£ 1,000$ for new students. However, other funding (teaching grants and fees paid by local authorities) was cut in equal measure, leaving total resources per student largely unchanged in real terms. Between 1998 and 2005, realterms increases in teaching grants provided led to an $11 \%$ increase in the level of resources available per student.

In 2006, tuition fees were increased from $£ 1,200$ to $£ 3,000$. This was a deliberate attempt to increase university resources, and the level of teaching grants was kept roughly constant while the maximum tuition fee increased. This led to a $28 \%$ increase in the overall level of resources per student universities received, although some of this increase was lost as resources per student fell over the following five years due to real-terms falls in teaching grants per student. 
University resources then increased by 19\% following the 2012 reforms: the large increase in tuition fee income more than outweighed the significant cut to teaching grants. However, not all courses have received the same increase in funding. Science and laboratory-based subjects that are more reliant on funding from teaching grants have experienced smaller increases in funding (between $6 \%$ and $19 \%$ ), while cheaper-to-teach subjects have experienced increases of more than $45 \%$ (Belfield et al., 2017). This has led to significant debate about the extent to which universities cross-subsidise the provision of different courses.

Since 2012-13, the level of university resources has remained largely unchanged. This is despite the fact the maximum cap on tuition fees has only increased by $£ 250$ in cash terms, resulting in a real-terms cut of $5 \%$. This stability of funding levels has been achieved by universities increasing tuition fee levels up to the maximum cap and cutting the level of fee waivers and bursaries provided to incoming students.

\subsection{Government finances}

The cost of financing this teaching and the cost of maintenance funding provided to students is split between taxpayers and graduates. In this and the following section, we show how reforms have affected how these costs are split. In doing so, we focus on the numerous reforms that have occurred since 2012, a brief summary of which is provided below.

The largest reform to the HE system in recent years occurred in 2012, when the maximum cap on tuition fees was almost tripled from $£ 3,375$ to $£ 9,000$. There were several other reforms alongside this: teaching grants were cut; the threshold above which graduates make repayments on their student loans was increased from $£ 15,000$ to $£ 21,000$; and the interest rate charged on student loans was increased.

Since then, there have been a number of important changes to the system. In 2016, the repayment threshold was frozen at $£ 21,000$ (instead of increasing in line with average earnings) and maintenance grants for students from low-income backgrounds were abolished. In 2017, the cap on fees was increased to $£ 9,250$ and frozen again in nominal terms, and the repayment threshold was increased to $£ 25,000$ and once again linked to earnings growth (more than reversing the freeze announced the year before).

To illustrate the impacts of these recent reforms on government finances and graduate contributions, in what follows we compare the impact that four distinct systems would have had on the cohort of graduates who started HE in 2017. ${ }^{99}$ We focus on the systems in place in 2011, 2012, 2017 (before the announcements in October of that year) and the current system. The details of each of these systems are summarised in Table 5.1.

Figure 5.2 shows how the total cost of providing HE (including the cost of maintenance loans and grants) for the cohort who entered university in 2017 would have varied under the various funding systems in place over the last seven years. This total cost is broken down into the sum expected to be paid by graduates repaying their student loans in the long run and the cost paid by the government/taxpayer. This taxpayer cost is then broken

49 This also holds the government discount rate constant at $0.7 \%$ for all systems. The rate used to evaluate the long-run cost of student finance was reduced from $2.2 \%$ to $0.7 \%$ in 2016. 
down into the money paid out in direct grants (teaching grants and maintenance grants) and the long-run cost of student loans that are not expected to be repaid. As the figure shows, the overall cost of the HE finance system has increased from $£ 15.1$ billion under the 2011 system to $£ 17.3$ billion under the current system. This increase has been funded by an increase in the graduate contribution, as the overall government cost has fallen over this period.

The overall long-run cost to the taxpayer for the cohort of students who entered HE in 2017 is expected to be around $£ 8.5$ billion, with graduates paying the remaining $£ 8.8$ billion..$^{50}$ However, the impact on the government deficit is significantly lower, at only $£ 800$ million. This is because only money paid out in direct grants (teaching grants or maintenance grants) counts towards the deficit. Money paid out in student loans does not show up in the short-term deficit even if a considerable proportion of this money is not expected to be repaid.

The reforms over the last seven years have significantly reduced the impact of the HE system on the deficit. Had the system remained unchanged since 2011, $£ 6.8$ billion worth of teaching and maintenance grants would have been paid out for the current cohort; however, instead, only $£ 800$ million of grants were paid out - a $90 \%$ ( $£ 6$ billion) reduction in the impact of $\mathrm{HE}$ on the deficit. This was driven by the cuts to teaching grants in 2012 (replaced with larger tuition fee income) and the abolition of maintenance grants in 2016

Table 5.1. Details of various HE systems in England

\begin{tabular}{|c|c|c|c|c|}
\hline & 2011 system & 2012 system & 2017 system & Current system \\
\hline Maximum fees & $\begin{array}{l}£ 3,375 \text { in } 2011 \text {, } \\
\text { increasing with } \\
\text { RPI thereafter }\end{array}$ & $\begin{array}{l}£ 9,000 \text { in } 2012 \text {, } \\
\text { increasing with } \\
\text { RPI thereafter }\end{array}$ & $\begin{array}{l}£ 9,250 \text { in } 2017 \text {, } \\
\text { increasing with } \\
\text { RPI thereafter }\end{array}$ & $\begin{array}{c}£ 9,250 \text { frozen in } \\
\text { nominal terms }\end{array}$ \\
\hline $\begin{array}{l}\text { Graduate } \\
\text { repayments } \\
\text { threshold }\end{array}$ & $\begin{array}{l}£ 15,000 \text { in } 2011 \\
\text { increasing } \\
\text { roughly with } \\
\text { nominal } \\
\text { earnings } \\
\text { growth }^{\mathrm{b}}\end{array}$ & $\begin{array}{l}£ 21,000 \text { in } 2016 \\
\text { increasing with } \\
\text { nominal } \\
\text { earnings growth } \\
\text { from } 2016\end{array}$ & $\begin{array}{l}£ 21,000 \text { in } 2017 \\
\text { increasing with } \\
\text { nominal } \\
\text { earnings growth } \\
\quad \text { from } 2021\end{array}$ & $\begin{array}{l}£ 25,000 \text { in } 2018 \\
\text { increasing with } \\
\text { nominal } \\
\text { earnings growth } \\
\text { from } 2018\end{array}$ \\
\hline $\begin{array}{l}\text { Interest rate on } \\
\text { loans }\end{array}$ & $\mathrm{RPI}^{\mathrm{c}}$ & RPI $+0-3 \%$ & RPI $+0-3 \%$ & RPI $+0-3 \%$ \\
\hline $\begin{array}{l}\text { Maintenance } \\
\text { grants }\end{array}$ & Yes & Yes & No & No \\
\hline Write-off & 25 years & 30 years & 30 years & 30 years \\
\hline
\end{tabular}

an reality, the pre-2012 fees were frozen in cash terms at $£ 3,465$ after 2012 (rather than increasing with the RPI) but this was not the policy proposal at the time.

${ }^{\mathrm{b}}$ In practice, this threshold was not increased exactly in line with nominal earnings growth between 2011 and 2018; see Figure 5.3.

${ }^{c}$ Actual policy is the minimum of base rate $+1 \%$ or Retail Prices Index (RPI) inflation. We assume it is RPI inflation in the long run.

50 This, and all other long-run figures in this section, are the net present value of the expected cost using the real government discount rate of $0.7 \%$. 
Figure 5.2. Cost of financing HE (2018 prices)

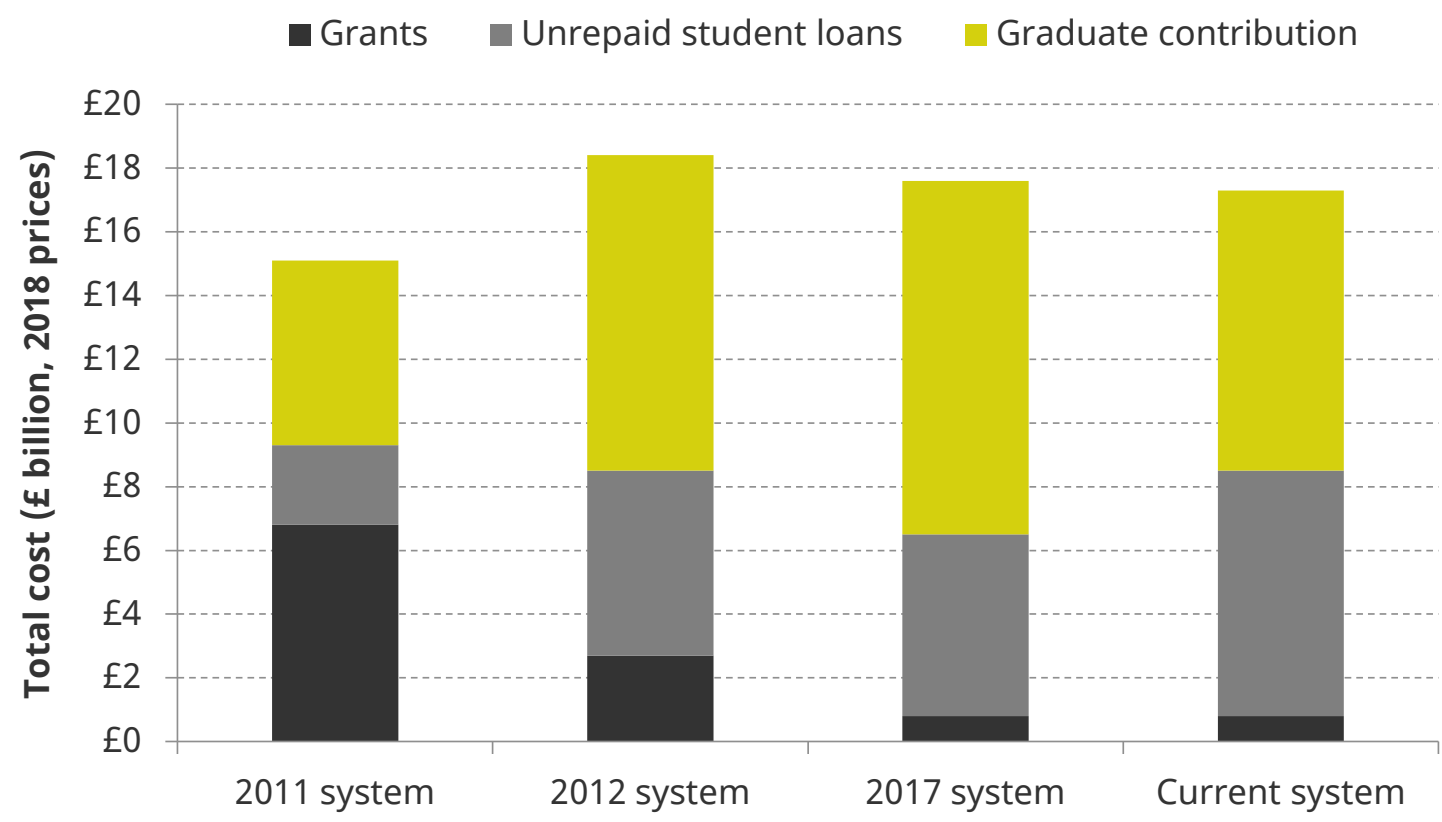

Note: All figures are given in 2018 prices, in net-present-value terms using the government discount rate of RPI $+0.7 \%$. These figures apply to young full-time England-domiciled students studying at the 90 largest universities in England starting in 2017-18. Cohort of students is held constant across systems. We assume that all students taking out loans do so for the full amount to which they are entitled, that there is no dropout from university, that graduates repay according to the repayment schedule and that they have low unearned income. This assumes cohort size of 365,700 based on 2015-16 Higher Education Statistics Agency (HESA) estimates of England-domiciled first-year full-time undergraduates. We assume 10\% non-take-up of loans, approximately in line with Student Loans Company (SLC) data on loan uptake. For data behind this graph, per-borrower figures and RAB charge estimates, see Table C.1 in Appendix C.

Source: Authors' calculations using IFS's graduate repayments model.

(replaced with larger maintenance loans). However, these reforms resulted in larger student loans with higher non-repayment rates. Whilst having no impact on the short-run deficit, they increase the long-run cost. As a result, the expected long-run government cost of providing HE has not fallen by nearly as much: the reforms between 2011 and 2017 reduced the expected long-run taxpayer cost per cohort from $£ 9.3$ billion to $£ 8.5$ billion - a saving of only $£ 800$ million.

In the context of large loans and high rates of non-repayment, apparently minor changes to the repayment parameters can have significant impacts on the long-run cost. This has been particularly evident in the recent reforms to the repayment threshold - the level of income above which graduates make repayments on their student loans. The 2012 reform increased the repayment threshold to $£ 21,000$ and linked it to growth in average earnings from 2017. However, in 2016, it was frozen in cash terms at $£ 21,000$ until 2021. This freeze was the main driver of the expected $£ 2$ billion reduction in long-run cost per cohort between the systems in place in 2012 and early 2017 (simultaneously replacing maintenance loans with maintenance grants also contributed to this saving). However, the announcement the following year to increase the threshold to $£ 25,000$ and reintroduce the earnings link more than reversed this change ${ }^{51}$ and increased the expected

51 The repayment threshold would have stood at around $£ 22,600$ in 2018 if neither reform had occurred. 
government cost by around $£ 2.3$ billion per cohort (Belfield, Britton and van der Erve, 2017). By comparison, the high-profile reforms in 2012 only reduced the long-run government cost by around $£ 700$ million.

Changing the repayment threshold has such a large impact on the long-run government cost for two reasons. First, because the thresholds are typically uprated in line with an index (e.g. average earnings), adjustments to the level have a permanent effect. For example, freezing the threshold in nominal terms until 2021 not only reduced the threshold in 2021, but the resulting threshold was lower in every year thereafter. Figure 5.3 shows projected paths of the repayment threshold over time under the four different systems. The announcement in October 2018 to increase the threshold to $£ 25,000$ and reintroduce the link with average earnings increased the threshold by $25 \%$ in every year from 2021 onwards. Second, in the context of the majority of students not fully repaying their student loans, changing the repayment threshold directly affects the value of loans that are written off after 30 years, rather than merely bringing forward or delaying payments that would have been made anyway.

The interest rates charged on student loans have received a lot of attention recently and they also have an impact on the government finances. A higher interest rate increases the debt levels of graduates and so they continue making repayments on their student loans for longer. However, for any graduates who have some debt written off at the end of the repayment period anyway, a higher interest rate merely increases the amount of debt written off and has no impact on the actual repayments they make. This means that, in the English context of high levels of debt write-off, lowering the interest rate predominantly reduces the level of debt write-off rather than graduate repayments. There would still be an increase in the long-run cost, however, resulting from lower repayments from highearning graduates: for example, lowering the interest rate from RPI plus $0-3 \%$ to RPI (the

\section{Figure 5.3. Repayment thresholds under various student loan systems (current prices)}

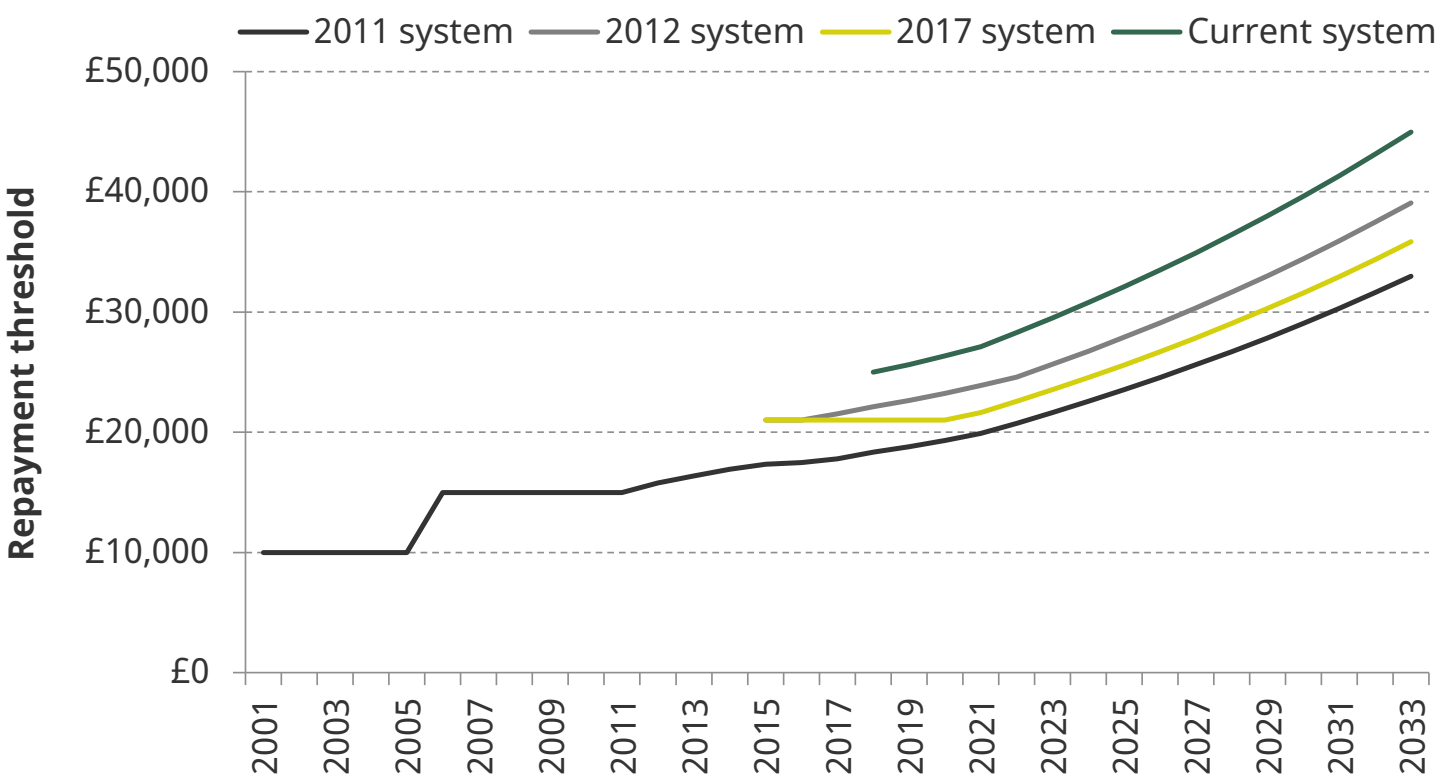

Source: Authors' calculations based on government announcements and forecasts of average weekly earnings growth from Office for Budget Responsibility (2018). 
rate for students starting before 2012) would increase the long-run government cost by around $£ 1.3$ billion (Belfield, Britton and Hodge, 2017).

In addition, due to government accounting rules, the interest rate directly impacts the government short-run deficit. Under the current accounting rules, the full value of the interest charged on student loans counts as income acting to reduce the government deficit, despite the fact that the vast majority of the interest graduates accrue is never actually repaid. This is not a trivial issue: in 2016-17, more than $£ 1.2$ billion worth of interest accrued on post-2012 loans and this will grow rapidly in future years as the size of the post-2012 loan book increases with additional cohorts passing through the system.

Finally, it is important to be clear that all the figures in this chapter are expected long-run costs and are based on assumptions about future graduate earnings growth and discount rates / government cost of borrowing. In an HE system funded by high levels of student debt, the long-run government cost is very sensitive to these projections. In previous work, we have shown that if long-run graduate earnings growth were 1 percentage point lower than expected, this could increase the long-run government cost by around $£ 1$ billion per cohort of students. Similarly, if the government discount rate (based on the cost of borrowing) were 1 percentage point higher, the estimated long-run cost for each cohort could be almost $£ 2$ billion higher (Belfield et al., 2017).

The combined effect of the reforms over the last seven years has been a small reduction in the expected long-run government cost of providing $\mathrm{HE}$ for the cohort of students who started university in 2017. However, this has been the result of a radical shift in the way HE is financed: under the 2011 system, $60 \%$ of the initial HE spending was in the form of loans; this has risen to $96 \%$ today. This has two important consequences. First, it dramatically reduces the impact of $\mathrm{HE}$ on the headline measure of government spending the deficit - as loan expenditure is not counted in the short run. Second, it significantly increases the sensitivity of government cost to future growth in graduate earnings and the government cost of borrowing.

\subsection{Graduate repayments}

The cost of HE that is not funded by the government is paid for by contributions graduates make on their student loans. As shown in Figure 5.4, under the system in 2011, the average graduate would have been expected to make around $£ 20,000$ of repayments over the lifetime of their loans. ${ }^{52}$ The reforms in 2012 increased this average expected contribution to $£ 39,000$. The major driver of this increase in graduate contributions was, predictably, the significant increase in the debt levels with which graduates leave university. Under the 2011 system, the average student on a three-year degree would have graduated with around $£ 25,000$ of debt. This rose to over $£ 50,000$ under the 2012 system (Belfield et al., 2017). The simultaneous increase in the interest rate and the extension of the repayment period to 30 years also increased graduate contributions, while increasing the repayment threshold from $£ 15,000$ to $£ 21,000$ acted to reduce average repayments.

52 This is in real terms and not discounted. If graduates discount future payments at a positive discount rate, the net present value of these payments will be lower. 


\section{Figure 5.4. Expected average lifetime repayments for 2017-18 cohort (2018 prices, not discounted)}

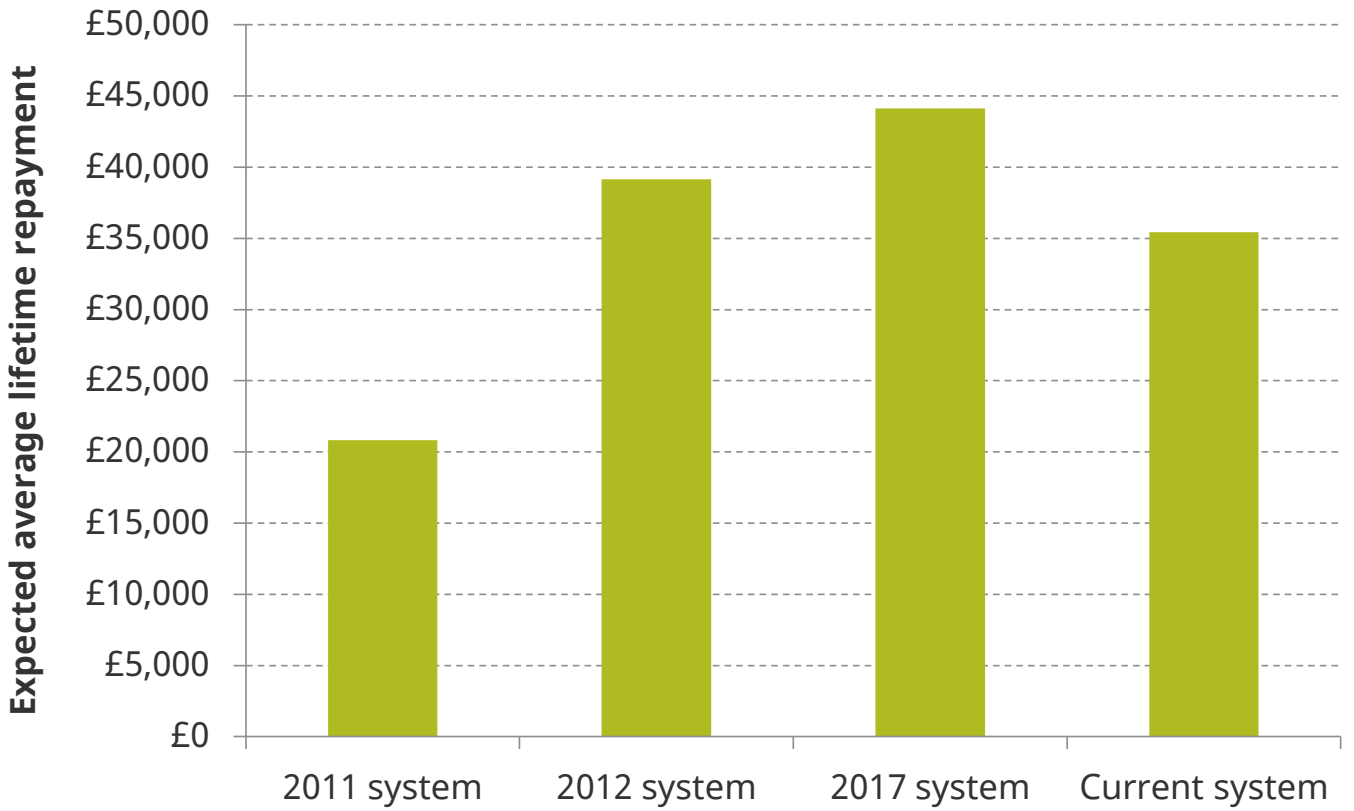

Note: Figures in 2018 prices, deflated using CPI inflation, not discounted. These figures apply to young full-time England-domiciled students studying at the 90 largest universities in England starting in 2017-18. We assume that all students take out the full loans to which they are entitled, that there is no dropout from university, that graduates repay according to the repayment schedule and that they have low unearned income.

Source: Authors' calculations using IFS's graduate repayments model.

Since 2012, the biggest impacts on graduate contributions have resulted from the changes to the repayment threshold. Previous work has shown that the five-year nominal freeze to the repayment threshold in 2016 was expected to increase average graduate repayments by around $£ 4,000$ (Belfield et al., 2017), while the subsequent reversal and increase to $£ 25,000$ announced in 2017 is expected to save the average graduate almost $£ 10,000$ in total (Belfield, Britton and van der Erve, 2017). ${ }^{53}$ Other reforms, such as replacing maintenance grants with loans, have increased expected graduate contributions, whilst freezing fee levels in nominal terms has reduced expected repayments. However, these effects have been small in magnitude, largely because small changes in debt levels do not affect the repayments made for the vast majority of graduates.

While the average graduate who entered HE in 2017 will end up paying considerably more than if they started university in 2011, this is not true of all graduates. In fact, as shown in Figure 5.5, the lowest-earning $40 \%$ of students that started in 2017 are expected to pay around $25 \%$ less towards their university education than they would have done if they had started university in 2011. This is entirely the result of the higher repayment threshold. As shown in Figure 5.3, the repayment threshold under the current system is more than $35 \%$ higher in the long run than under the 2011 system. This means that graduates pay less in every year for the duration of their loans. The other reforms have simply increased the length of time for which graduates have loans outstanding. Low-earning graduates would have taken almost the full 25 years to repay the smaller pre-2011 loans (or not fully repaid

53 These figures do not directly relate to the numbers in Figure 5.4 as graduate earnings projections have been updated. 


\section{Figure 5.5. Expected average lifetime repayments by decile of graduate lifetime income for 2017-18 cohort (2018 prices, not discounted)}

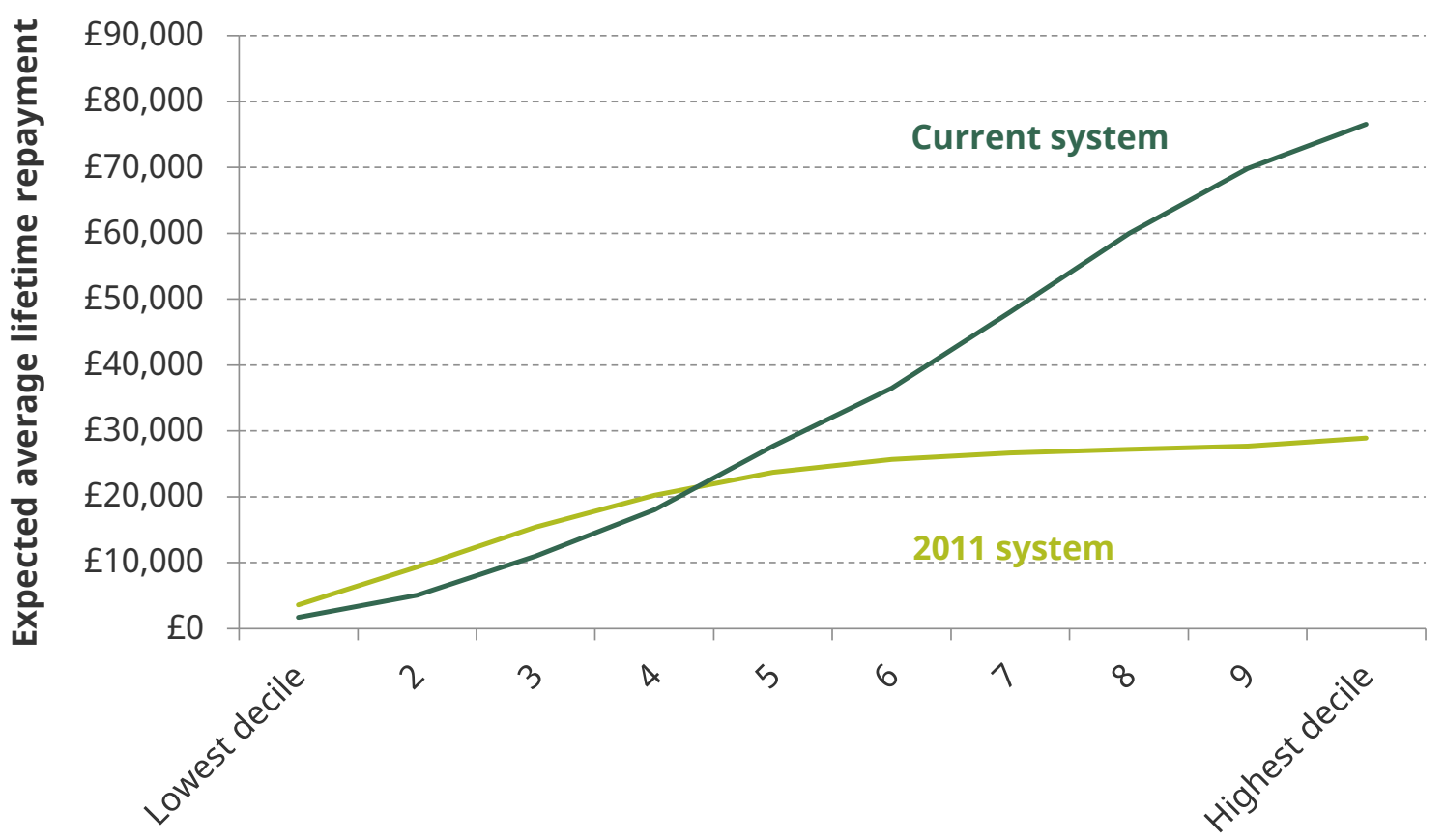

Note: Figures in 2018 prices, deflated using CPI inflation, not discounted. These figures apply to young full-time England-domiciled students studying at the 90 largest universities in England starting in 2017-18. We assume that all students take out the full loans to which they are entitled, that there is no dropout from university, that graduates repay according to the repayment schedule and that they have low unearned income.

Source: Authors' calculations using IFS's graduate repayments model.

them) and so increasing their debt levels simply increases the amount written off at the end of the repayment period.

By contrast, the $20 \%$ of graduates with the highest lifetime earnings pay significantly more under the current system: they are expected to repay more than $£ 70,000$ on average under the current system, compared with less than $£ 30,000$ if they had started university in 2011. This is because they repay most, or all, of the now significantly higher debt levels, and the higher interest rates act to increase these debt levels further. Our latest estimates suggest that the higher interest rates alone increased the repayments of the richest $20 \%$ of graduates by more than $£ 20,000$ (Belfield, Britton and Hodge, 2017).

\subsection{Potential upcoming reforms}

In this section, we highlight the challenges that might face the HE system over the coming years. Despite continual reforms to the HE system over the last seven years, the government is currently undertaking a wide-ranging review of the post-18 education system that may result in further reforms to the system. Reports by the Treasury Select Committee (2018) and the House of Lords Economic Affairs Committee (2018) have highlighted two potential changes that might come out of this review: reintroducing maintenance grants and reducing the interest rates. In addition, Labour's manifesto in the 2017 election pledged to abolish tuition fees entirely. We consider the impact of these three potential reforms on the overall system of HE in England. 


\section{Reintroducing maintenance grants}

In 2016, the government got rid of maintenance grants and replaced them with a new means-tested maintenance loan. One consequence of this decision is that students from lower-income families graduate with higher debt than their better-off peers. The $40 \%$ of students from the lowest-income families graduate with an average debt of around $£ 56,000$ from a three-year degree, while students from the richest families graduate with around $£ 42,000$ of student debt (Belfield, Britton and Hodge, 2017).

Reintroducing maintenance grants at a similar level to before could reduce the debt levels on graduation of students from low-income families. This would not impact the amount of money the government pays out up front: spending on loans would simply be replaced by spending on grants. However, this would increase the deficit impact of HE by around $£ 2$ billion per cohort (as grants are included in deficit figures while loans are not). In the long run, the cost of this policy would be substantially lower than the immediate deficit impact. A considerable proportion of today's maintenance loans are not expected to be repaid. Belfield, Britton and Hodge (2017) estimate the long-run cost of reintroducing maintenance grants is around $£ 340$ million per cohort, roughly $4 \%$ of the taxpayer cost of providing $\mathrm{HE}$.

The main beneficiaries of reintroducing maintenance grants would be graduates from low-income backgrounds who go on to have high earnings. Students who get full maintenance grants and are in the top $10 \%$ of graduate earners would save an average of $£ 22,000$ over their lifetimes. Their peers who are eligible for full maintenance grants but are not in the $40 \%$ highest-earning would face little or no change in their lifetime repayments, as they are not expected to pay off the additional maintenance loan anyway (Belfield, Britton and Hodge, 2017).

\section{Reducing the interest rate}

The select committees have also repeatedly criticised the high interest rate charged on student loans. One option would be to reduce the interest rate to RPI inflation for all graduates (as is already the case for students who entered HE before 2012). Belfield, Britton and Hodge (2017) show that this would cost the government around $£ 1.3$ billion per cohort in the long run. Again, this reform would benefit high-earning graduates: in fact, the lowest-earning $70 \%$ of graduates would experience no change at all in their lifetime repayments, while the highest-earning $20 \%$ of graduates would save more than $£ 20,000$.

The government accounting rules provide a disincentive to reducing the interest rate. The full value of interest accrued on student loans counts as income to reduce the deficit, despite the fact that much of this interest will never actually be repaid. Reducing the interest rate on student loans would reduce this source of government 'income' in the national accounts - though, as outlined in Section 5.2, it would have a much smaller impact on the actual money received by the government over the next 30 years.

\section{Abolishing tuition fees}

In their manifesto for the election in June 2017, Labour committed to scrap tuition fees and replace university funding with increased teaching grants. This would have a number of important consequences for the HE system. First, it would only increase up-front government spending by around $£ 1$ billion, around $6 \%$. This is because the increased cost of teaching grants would simply replace money that is currently paid out in tuition fee 
loans. The extra $£ 1$ billion is the additional cost of teaching grants to replace the fee income of the students who currently pay their own fees up front without government loans. However, because these additional teaching grants count towards the deficit, scrapping fees would increase the deficit impact from $£ 800$ million to more than $£ 11$ billion. Second, the long-run cost of providing HE would increase by around $£ 5$ billion (a $60 \%$ increase), resulting from the reduced graduate repayments on significantly smaller student loans. Finally, the highest-earning graduates would benefit the most. The lowestearning graduates would not save much money as they do not make considerable repayments on their student loans (and they would still have to repay their maintenance loans), while the highest-earning graduates, who pay off most of their student loans, could benefit by more than $£ 50,000$ over their lifetimes.

\subsection{Future challenges}

A key challenge facing the HE system is ensuring the quality of education provided in a market where students lack good information about the return to their degrees. The government highlighted this as an area of concern in the White Paper Success as a Knowledge Economy (Department for Business, Innovation and Skills, 2016).

The introduction of the new Teaching Excellence Framework was designed to address this issue by providing students and universities with direct metrics on the quality of education provided. Originally, the government planned that these metrics would be used to determine which universities could increase fees in line with inflation, thereby creating monetary incentives for universities to improve their performance. However, now that all fees have been frozen in nominal terms, this policy has been abandoned.

The challenge for the government is to define and produce the metrics on which it wants universities to perform, and incentivise universities to take these metrics seriously. The government has taken steps in this direction by publishing measures of the impact universities have on their graduates' earnings, accounting for differences in the types of students they take (Belfield et al., 2018). This provides valuable insight both for students making important decisions about what and where to study and for universities seeking to understand the areas where they perform well and where they could improve. However, the impact on graduate earnings is clearly not the only metric that universities are or should be judged on. If the government wants to create incentives for universities to work towards a wide range of outcomes, it needs to ensure regulators and students have the relevant information to assess their performance.

Finally, there is the challenge of ensuring sustainable funding for the HE sector in the coming years. Since 2012, the real value of the maximum fee cap has fallen by $5 \%$ in real terms. As fees now make up more than $90 \%$ of universities' teaching income, this decline poses a significant risk to funding levels. Universities have maintained funding levels over this period by increasing fees (up to the cap) and cutting the provision of fee waivers and bursaries. However, these trends are not sustainable in the long term. If the maximum fee cap and teaching grant levels remain frozen in nominal terms, this will lead to declines in the overall level of funding per student.

The university sector is no stranger to falling levels of resources: funding per degree fell by $25 \%$ between $1990-91$ and $1997-98$ and again by $9 \%$ between $2006-07$ and $2011-12$. 
However, the pattern of falling resources per student corrected by large tuition fee reforms is far from the optimal path for university funding. The government should take the opportunity afforded by the current review of the post-18 education system to develop and set out a comprehensive plan for funding higher education, now and in the future. 


\section{Comparisons and conclusions}

The shape of public spending on education has changed significantly since the early 1990s. In 1990-91, there was a very clear gradient across education stages: the older the pupils being taught, the higher the level of public spending (or resources) per pupil per year. Although this broadly remains true in 2017-18, the relative differences are smaller. Figure 6.1a compares these trends in public spending per student on various stages of education over time in England, whilst Figure $6.1 \mathrm{~b}$ shows the levels relative to primary school spending per pupil.

For higher education, we focus on total resources per student, rather than the long-run government subsidy - e.g. for the present day, it is total fees plus teaching grant and so includes the amount paid for by graduate contributions. We use this figure as we feel it best reflects the up-front resources going into higher education from government. For other stages of education, we focus on just the level of public subsidy as all other private spending comes directly from households and there is no evidence to suggest this has changed differentially over time.

At the start of the period, in 1990-91, higher education spending was $£ 8,000$ per student per year (this and all figures here are in 2018-19 prices), about four times the level of primary school spending per pupil, and it all came directly from government spending. Further education spending was around $£ 5,000$ per student and just over 2.5 times the

Figure 6.1a. Spending per pupil or student per year at different stages of education: actual and plans (2018-19 prices)

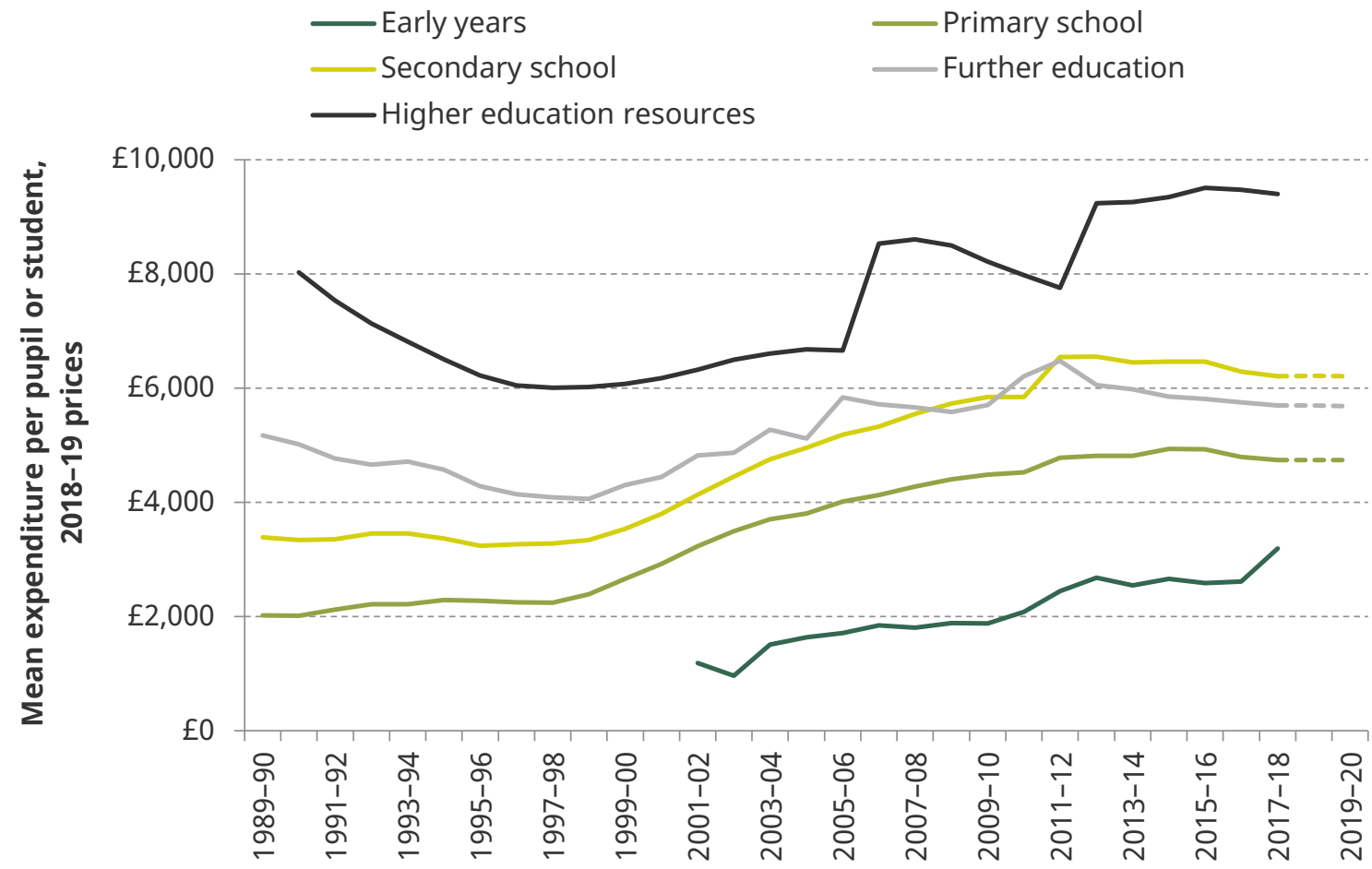

Source: Early years figures are for 3- and 4-year-olds. Further education figures are for ages 16-18. Higher education figures are the cohort-based numbers shown in Figure 5.1, divided by 3 - an approximate course length. See Figures 3.1 and 5.1, Appendix A and Table B.1 for full sets of notes, sources and numbers. 
Figure 6.1b. Relative spending per pupil or student per year at different stages of education: actual and plans (primary school spending per pupil $=1$ )

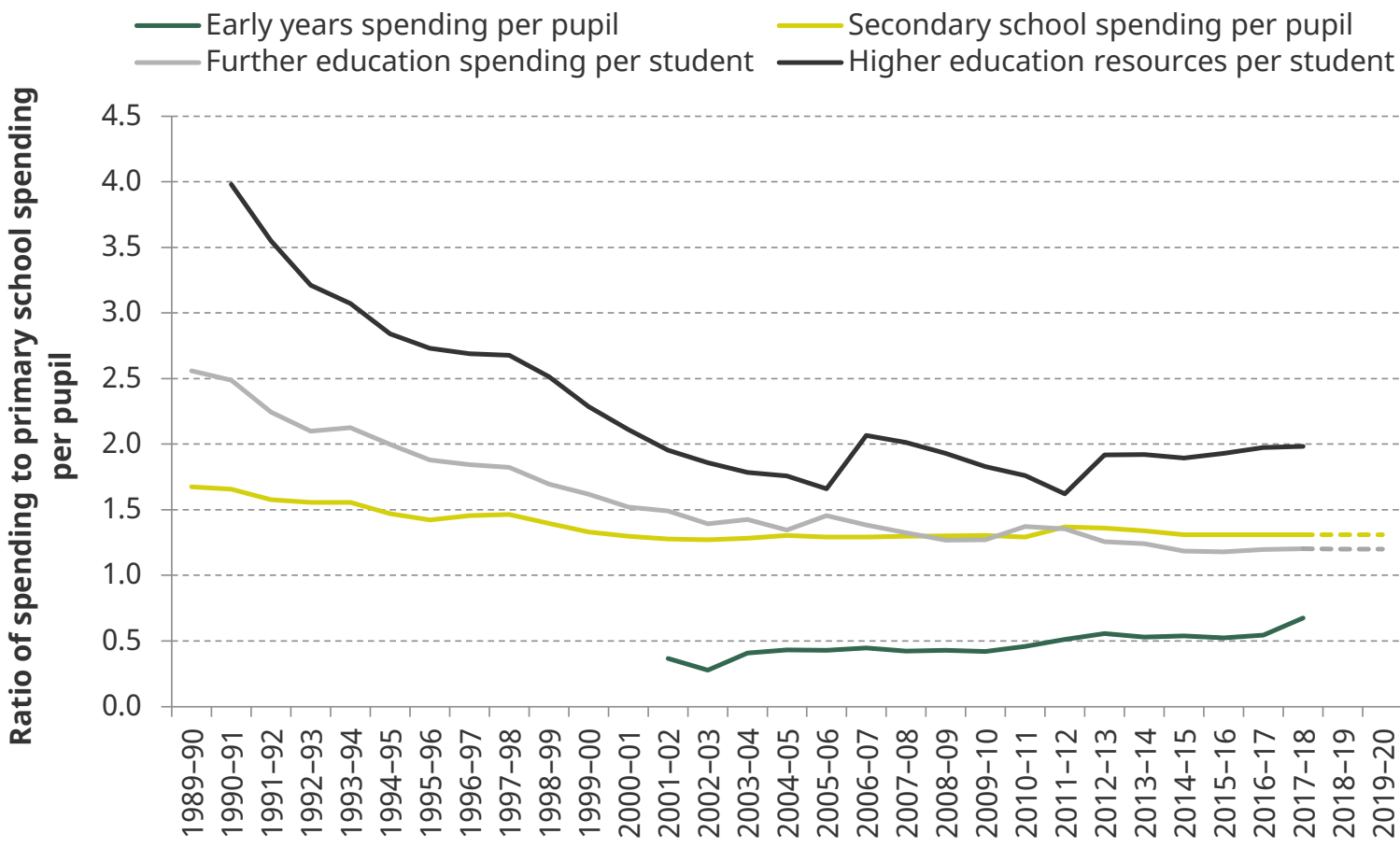

Source: See Figure 6.1a.

level of primary school spending (and nearly 1.5 times the level of secondary school spending per pupil). Secondary school spending was $£ 3,300$ per pupil, about 1.7 times the level of primary school spending per pupil $(£ 2,000)$. Early years spending was very low (less than $£ 100$ million in total) and is not shown on this graph as a result.

Over the next 25 years, there were then significant changes in this balance of spending, with three distinct phases of change: falls in spending (1990-91 to 1997-98); rapid growth (1997-98 to 2010-11); and differential protections from spending cuts (2010-11 onwards).

During the period of falls in spending in the 1990s, 16-18 education and higher education spending per student both fell significantly in real terms, by around $20 \%$ and $25 \%$ respectively between 1990-91 and 1997-98. In contrast, primary and secondary school spending per pupil were largely frozen in real terms, shrinking the gap between school spending per pupil and post-compulsory education spending per student.

From 1997-98 to 2010-11, spending and resources increased across all stages of education. The early years entitlement was introduced and then extended over time. There were some very significant increases in school spending per pupil, with primary school spending per pupil growing by $5.6 \%$ per year and secondary school spending per pupil by 4.5\% per year, on average, in real terms between 1997-98 and 2010-11. Further education spending per student also grew significantly over the period, but by a slightly slower rate, at around 3\% per year on average in real terms. As a result, by the late $2000 \mathrm{~s}$, the level of spending per pupil in secondary school was similar to that in 16-18 education, a dramatic turnaround compared with the picture in the early 1990 s. 
Resources for higher education increased slightly in real terms, by around $11 \%$ between 1997-98 and 2005-06, as the real value of teaching grants per student increased. The increase in the tuition fee cap to $£ 3,000$ then led to a large uptick in resources. However, these increases were not enough to keep pace with the growth in primary school spending over this period. In 1997-98, higher education received more than 2.5 times as much funding per pupil as primary schools, but by 2011-12 this had fallen to a little over 1.5 times as much. This is a dramatic shift in the relative priorities of these spending areas.

From 2010-11 onwards, early years spending per head continued to rise as the scope of the free entitlement was expanded, first to 15 hours in 2010 and then to 30 hours for working parents in 2017. School spending per pupil was largely protected in real terms up to 2015 , before then falling by about 4\% in real terms between 2015-16 and 2017-18 and then being protected again up to 2019-20. There were larger falls in further education spending per student, which fell by $8 \%$ in real terms between 2010-11 and 2017-18, leading spending on 16-18 education to fall significantly behind spending on secondary schools for the first time in at least 25 years and probably a lot longer. Higher education saw a large increase in resources per student as a result of the increase in tuition fees in 2012 and these resources have remained relatively steady since then. As we showed in Chapter 5, however, this increase in resources was driven by increased expected graduate contributions.

By 2017-18, we see a much more complex picture than we saw in 1990. Higher education resources per student continue to be higher than resources at all other stages, but only due to graduate contributions, and the changes over time have been far from smooth. School spending has been prioritised by successive governments, whilst 16-18 education has been the big loser from changes over the last 25 years, with spending per student in further education now $8 \%$ below that in secondary schools. Early years spending has been a focus of successive governments too, though spending per pupil is still only around $70 \%$ of that in primary schools, and we know there have been cuts to other early years services such as Sure Start. This provides an important context for the challenges each stage of education faces in the years to come.

Overall, the picture of government spending on education has changed significantly over the last 25 years, with the focus of spending shifting towards earlier in youngsters' lives. Most stages of education have seen significant real-terms increases in spending per pupil over this period, with 16-18 education a notable exception. To inform the public debate, we plan to use our annual reports to update our estimates of spending per pupil at each education stage on a yearly basis. 


\section{Appendix A. Early years spending data}

In constructing a series of spending on early education, we combined information from several data sources, each of them imperfect. We used budget data from the Section 251 summary budget tables and data on spending (out-turns) from the Department for Education's Statistical First Release SFR52 series. We also had available data from the Section 251 out-turns.

Table A.1 summarises the availability of these different sources of data and the total spending figures implied by each (all in 2018-19 prices). Sources for each type of data are

Table A.1. Total spending on the 3- and 4-year-old free entitlement, by data source (£000s, 2018-19 prices)

\begin{tabular}{|c|c|c|c|c|}
\hline & $\begin{array}{c}\text { Nursery } \\
\text { Education Grant }\end{array}$ & Budget & Spend, Section 251 & Spend, SFR52 \\
\hline 1997-98 & 941,853 & & & \\
\hline 1998-99 & 963,568 & & & \\
\hline 1999-00 & & & & \\
\hline $2000-01$ & & & & \\
\hline $2001-02$ & & 532,684 & 948,896 & \\
\hline $2002-03$ & & 578,055 & 760,695 & \\
\hline $2003-04$ & & $1,065,523$ & $1,169,571$ & \\
\hline 2004-05 & & $1,126,883$ & $1,237,363$ & \\
\hline 2005-06 & & $1,135,053$ & $1,281,486$ & \\
\hline $2006-07$ & & $1,220,125$ & $1,396,127$ & \\
\hline 2007-08 & & $1,267,704$ & $1,412,275$ & \\
\hline 2008-09 & & $1,293,239$ & $1,511,586$ & \\
\hline $2009-10$ & & $1,379,570$ & $1,547,744$ & \\
\hline $2010-11$ & & $1,768,527$ & $1,435,912$ & \\
\hline $2011-12$ & & $2,143,402$ & $1,471,420$ & \\
\hline $2012-13$ & & $2,378,187$ & $1,385,116$ & \\
\hline $2013-14$ & & $2,276,258$ & & $2,100,566$ \\
\hline 2014-15 & & $2,435,410$ & & $2,168,451$ \\
\hline $2015-16$ & & $2,426,328$ & & $2,334,966$ \\
\hline $2016-17$ & & $2,435,690$ & & $2,394,715$ \\
\hline 2017-18 & & $2,979,856$ & & \\
\hline
\end{tabular}


available via embedded hyperlinks for the spending figures, except for the Nursery Education Grant figures. ${ }^{54}$

The budget data are based on the Individual Schools Budget for nursery schools (2001-02 to 2009-10) and for early years (2010-11 to 2017-18). From 2012-13 onwards, they net out spending on the 2-year-old free entitlement. ${ }^{55}$ Section 251 out-turns data are calculated as net current spend from nursery schools and PVI providers plus net current central spend on nursery schools.

We believe that the data series have the following limitations:

- Budget data between 2001-02 and 2009-10 likely exclude spending on nursery classes.

- Spending figures from the Section 251 returns do not explicitly include spending on the free entitlement as delivered by PVI providers.

Since we do not believe that spending was overstated in any of these years, our decision has been to use the most complete measure of spending available in each period up to 2012-13 to provide the most accurate figures possible. Since 2012-13, the trends in the budget and SFR52 spending data have tracked each other closely. We have preferred the budget measures for these years to avoid another break in the data series and in order to get first estimates for the changes in spending in 2017-18 from a consistent data source. This means that our figures do the following:

- 1997-98 to 1998-99: Use spending on the Nursery Education Grant.

- 1999-2000 to 2000-01: There are no spending data in 1999-2000, and spending data in 2000-01 are incomplete. Do not report spending figures for these years.

- 2001-02 to 2009-10: Use the Section 251 spending data as they explicitly include spending on PVI provision of the free entitlement (while the budget data are likely to exclude spending on nursery classes).

- 2010-11 to 2012-13: Use the budget data (which now relate to all early years spending) as they are likely to be more comprehensive.

- 2013-14 to 2017-18: Budget and SFR52 spending data track each other closely. Continue to use the budget data to provide a more consistent series and to report on planned spending levels in 2017-18.

54 Spending in 1997-98 and 1998-99 represents reported central government spending on nursery vouchers through the Nursery Education Grant listed in Department for Education and Employment (1999).

55 Spending on the 2-year-olds offer is directly reported in the 2012-13 budget table. In 2013-14, it comes from the National Audit Office's report on the free entitlement (National Audit Office, 2016, fig. 7). From 2014-15 onwards, it comes from the early years table of the budget data. 


\section{Appendix B. Further education and sixth forms: sources and methodology}

In this appendix, we provide a summary of how we constructed our series for spending per student in further education colleges (including sixth-form colleges) and school sixth forms. Table B.1 gives full details of the numbers and sources used.

From 2002-03 to 2017-18, we are able to calculate both sets of figures as total reported spending on further education or on school sixth forms for students aged 16-18 divided by the full-time-equivalent numbers of students attending each sector. In 2017-18, we assume a cash-terms freeze in spend per student observed in each sector, which is then rescaled so that multiplying by the number of students gives the total reported allocation. This slightly different approach is undertaken because of a large number of conversions of sixth-form colleges to academy status since April 2017. Pupils in sixth-form colleges that have converted to academy status are counted as being in school sixth forms in the student data, which is a different categorisation from in the funding data, which are recorded earlier in the financial year. Beyond 2017-18, we project spending per student as being frozen in cash terms, based on the Chancellor's commitment in the 2015 Spending Review to freeze the national base rate for 16-18 education in cash terms and an additional policy announcement regarding funding for the implementation of T levels in Spring Budget 2017.

Before 2003-04, figures for spending per student in further education are available from various departmental and Office for National Statistics publications. These give slightly different levels for spending per student in 2003-04 from the more recent source. We therefore take the more reliable 2003-04 figure and back-cast imputed figures based on past changes in spending per student in further education. Figures for spending per student in school sixth forms are not readily available before 2002-03. 
Table B.1. Spending on and numbers of students in further education and sixth forms

\begin{tabular}{|c|c|c|c|c|c|c|c|}
\hline & \multicolumn{4}{|c|}{ Further education } & \multicolumn{3}{|c|}{ School sixth forms } \\
\hline & $\begin{array}{c}\text { Total } \\
\text { allocation, } \\
\text { fbn (2018- } \\
19 \text { prices) }\end{array}$ & $\begin{array}{l}\text { Calculated } \\
\text { spending } \\
\text { per student } \\
\text { (2018-19 } \\
\text { prices) }\end{array}$ & $\begin{array}{l}\text { Imputed } \\
\text { spending } \\
\text { per student } \\
\text { (2018-19 } \\
\text { prices) }\end{array}$ & $\begin{array}{l}\text { 16- to 18- } \\
\text { year- } \\
\text { olds } \\
\text { (FTE) }\end{array}$ & $\begin{array}{c}\text { Total } \\
\text { allocation, } \\
\text { fbn (2018-19 } \\
\text { prices) }\end{array}$ & $\begin{array}{l}\text { Calculated } \\
\text { spending } \\
\text { per student } \\
\text { (2018-19 } \\
\text { prices) }\end{array}$ & $\begin{array}{l}\text { 16- to 18- } \\
\text { year- } \\
\text { olds } \\
\text { (FTE) }\end{array}$ \\
\hline 1989-90 & & $£ 5,515$ & $£ 5,170$ & 527,550 & & & 254,700 \\
\hline 1990-91 & & $£ 5,352$ & $£ 5,018$ & 527,550 & & & 254,700 \\
\hline 1991-92 & & $£ 5,086$ & $£ 4,768$ & 548,550 & & & 270,600 \\
\hline 1992-93 & & $£ 4,968$ & $£ 4,657$ & 552,850 & & & 276,300 \\
\hline 1993-94 & & $£ 5,027$ & $£ 4,713$ & 559,950 & & & 274,300 \\
\hline 1994-95 & & $£ 4,879$ & $£ 4,574$ & 543,600 & & & 277,100 \\
\hline 1995-96 & & $£ 4,569$ & $£ 4,283$ & 555,450 & & & 290,100 \\
\hline 1996-97 & & $£ 4,421$ & $£ 4,144$ & 576,450 & & & 308,100 \\
\hline 1997-98 & & $£ 4,654$ & $£ 4,089$ & 570,200 & & & 317,200 \\
\hline 1998-99 & & $£ 4,618$ & $£ 4,058$ & 548,700 & & & 318,100 \\
\hline 1999-00 & & $£ 4,895$ & $£ 4,301$ & 542,100 & & & 324,200 \\
\hline 2000-01 & & $£ 5,058$ & $£ 4,445$ & 536,500 & & & 329,700 \\
\hline 2001-02 & & $£ 5,487$ & $£ 4,821$ & 545,100 & & & 332,700 \\
\hline 2002-03 & & $£ 5,544$ & $£ 4,871$ & 562,850 & 1.92 & $£ 5,625$ & 341,350 \\
\hline 2003-04 & 3.04 & $£ 5,275$ & $£ 5,275$ & 576,800 & 2.05 & $£ 5,831$ & 351,350 \\
\hline 2004-05 & 3.08 & $£ 5,117$ & $£ 5,117$ & 601,600 & 2.16 & $£ 5,952$ & 363,300 \\
\hline 2005-06 & 3.65 & $£ 5,840$ & $£ 5,840$ & 625,250 & 2.27 & $£ 6,136$ & 370,050 \\
\hline 2006-07 & 3.75 & $£ 5,718$ & $£ 5,718$ & 655,050 & 2.40 & $£ 6,327$ & 379,350 \\
\hline 2007-08 & 3.81 & $£ 5,661$ & $£ 5,661$ & 672,850 & 2.46 & $£ 6,295$ & 390,250 \\
\hline 2008-09 & 3.87 & $£ 5,582$ & $£ 5,582$ & 693,900 & 2.48 & $£ 6,129$ & 404,900 \\
\hline 2009-10 & 4.14 & $£ 5,700$ & $£ 5,700$ & 725,500 & 2.55 & $£ 6,015$ & 423,550 \\
\hline 2010-11 & 4.52 & $£ 6,208$ & $£ 6,208$ & 728,400 & 2.74 & $£ 6,311$ & 434,150 \\
\hline 2011-12 & 4.56 & $£ 6,478$ & $£ 6,478$ & 704,050 & 2.71 & $£ 6,228$ & 434,450 \\
\hline 2012-13 & 4.23 & $£ 6,051$ & $£ 6,051$ & 698,450 & 2.58 & $£ 5,857$ & 440,750 \\
\hline 2013-14 & 4.16 & $£ 5,982$ & $£ 5,982$ & 695,550 & 2.42 & $£ 5,355$ & 451,950 \\
\hline 2014-15 & 4.05 & $£ 5,852$ & $£ 5,852$ & 691,250 & 2.37 & $£ 5,184$ & 456,750 \\
\hline 2015-16 & 3.94 & $£ 5,811$ & $£ 5,811$ & 678,350 & 2.31 & $£ 5,155$ & 448.700 \\
\hline 2016-17 & 3.79 & $£ 5,747$ & $£ 5,747$ & 658,800 & 2.20 & $£ 5,006$ & 439,950 \\
\hline 2017-18 & 3.52 & $£ 5,698$ & $£ 5,698$ & 616,850 & 2.25 & $£ 4,963$ & 452,950 \\
\hline
\end{tabular}


Note: Number of full-time-equivalent (FTE) students is calculated as number of full-time students plus 0.5 times number of part-time students.

Source: Spending per student for 2003-04 to 2017-18 calculated as spending on further education for 16- to 19year-olds and sixth-form spending (maintained schools and academies), as reported in Education and Skills Funding Agency annual report and accounts for 2017-18

(https://www.gov.uk/government/publications/education-and-skills-funding-agency-annual-report-andaccounts-2017-to-2018), Education Funding Agency annual report and accounts for 2012-13 to 2016-17 (https://www.gov.uk/government/publications/education-funding-agency-annual-report-and-accounts-2016-to2017, https://www.gov.uk/government/publications/efa-annual-report-and-accounts-for-the-year-ended-31march-2016, https://www.gov.uk/government/publications/efa-annual-report-and-accounts-for-the-year-ended31-march-2015, https://www.gov.uk/government/publications/efa-annual-report-and-accounts-1-april-2013-to31-march-2014, https://www.gov.uk/government/publications/efa-annual-report-and-financial-statements-forapril-2012-to-march-2013), Young People's Learning Agency annual report and accounts for 2011-12 (https://www.gov.uk/government/publications/the-young-peoples-learning-agencys-annual-report-andaccounts-for-2011-to-2012) and Learning and Skills Council annual report and accounts for 2004-05 to 2009-10 (https://www.gov.uk/government/publications?departments\%5B\%5D=learning-and-skills-council), divided by number of full-time-equivalent students aged 16-18 in further education colleges and school sixth forms. Number of students taken from Department for Education, 'Participation in education, training and employment: 2017' (https://www.gov.uk/government/statistics/participation-in-education-training-and-employment-2017). Figures for spending per student in further education from 1990-91 to 2003-04 taken from Department for Children, Schools and Families departmental report for 2009 (http://webarchive.nationalarchives.gov.uk/20130401151715/http://www.education.gov.uk/publications/eOrderi ngDownload/DCSF-Annual\%20Report\%202009-BKMK.PDF) and Department for Education and Employment, 'Education and training expenditure since 1989-90', Statistical Bulletin 10/99 (http://dera.ioe.ac.uk/13586/1/Education_and_training_expenditure_since_198990_\%28Statistics_Bulletin_10_99\%29.pdf). Imputed figures are calculated by back-rating the calculated figure in 2003-04 by the real-terms growth in the calculated series (figures for overlapping years are not shown here). HM Treasury deflators, March 2018 (https://www.gov.uk/government/statistics/gdp-deflators-at-market-prices-andmoney-gdp-march-2018-quarterly-national-accounts). 


\section{Appendix C. Higher education}

Table C.1. Money flows under various student finance systems (2018 prices)

\begin{tabular}{|c|c|c|c|c|}
\hline & $\begin{array}{c}2011 \\
\text { system }\end{array}$ & $\begin{array}{c}2012 \\
\text { system }\end{array}$ & $\begin{array}{c}2017 \\
\text { system }\end{array}$ & $\begin{array}{l}\text { Current } \\
\text { system }\end{array}$ \\
\hline RAB charge & $33.0 \%$ & $36.8 \%$ & $34.1 \%$ & $46.8 \%$ \\
\hline \multicolumn{5}{|l|}{ Cost per borrower } \\
\hline Total up-front government spend & $£ 43,700$ & $£ 55,200$ & $£ 53,300$ & $£ 52,300$ \\
\hline Of which, loans & $60 \%$ & $86 \%$ & $96 \%$ & $96 \%$ \\
\hline Long-run graduate contribution & $£ 17,600$ & $£ 30,000$ & $£ 33,800$ & $£ 26,700$ \\
\hline Long-run taxpayer subsidy & $£ 26,100$ & $£ 25,100$ & $£ 19,600$ & $£ 25,600$ \\
\hline \multicolumn{5}{|l|}{$\begin{array}{l}\text { Total costs (including non- } \\
\text { borrowers) }\end{array}$} \\
\hline Total up-front government spend & $£ 15,100 m$ & $£ 18,400 \mathrm{~m}$ & $£ 17,600 \mathrm{~m}$ & $£ 17,300 \mathrm{~m}$ \\
\hline Of which, direct grants & $£ 6,800 m$ & $£ 2,700 \mathrm{~m}$ & $£ 800 m$ & $£ 800 \mathrm{~m}$ \\
\hline $\begin{array}{l}\text { Total long-run government } \\
\text { contribution }\end{array}$ & $£ 9,300 \mathrm{~m}$ & $£ 8,500 \mathrm{~m}$ & $£ 6,500 \mathrm{~m}$ & $£ 8,500 \mathrm{~m}$ \\
\hline
\end{tabular}

Note: All figures are given in 2018 prices, in net-present-value terms using the government discount rate of RPI $+0.7 \%$. These figures apply to young full-time England-domiciled students studying at the 90 largest universities in England starting in 2017-18. Cohort of students is held constant across systems. We assume that all students taking out loans do so for the full amount to which they are entitled, that there is no dropout from university, that graduates repay according to the repayment schedule and that they have low unearned income. This assumes cohort size of 365,700 based on 2015-16 Higher Education Statistics Agency (HESA) estimates of England-domiciled first-year full-time undergraduates. We assume $10 \%$ non-take-up of loans, approximately in line with Student Loans Company (SLC) data on loan uptake.

Source: Authors' calculations using IFS's graduate repayments model. 


\section{References}

Amin-Smith, N., Cribb, J. and Sibieta, L. (2017), 'Reforms to apprenticeship funding in England', in C. Emmerson, P. Johnson and R. Joyce (eds), The IFS Green Budget: February 2017 (https://www.ifs.org.uk/publications/8863).

Belfield, C., Britton, J., Buscha, F., Dearden, L., Dickson, M., van der Erve, L., Sibieta, L., Vignoles, A., Walker, I. and Zhu, Y. (2018), The Relative Labour Market Returns to Different Degrees, Research Report, Department for Education

(https://www.gov.uk/government/publications/undergraduate-degrees-relative-labourmarket-returns).

Belfield, C., Britton, J., Dearden, L. and van der Erve, L. (2017), 'Higher education funding in England: past, present and options for the future', Briefing Note no. BN211, Institute for Fiscal Studies (https://www.ifs.org.uk/publications/9334).

Belfield, C., Britton, J. and Hodge, L. (2017), 'Options for reducing the interest rate on student loans and reintroducing maintenance grants', Briefing Note no. BN221, Institute for Fiscal Studies (https://www.ifs.org.uk/publications/10154).

Belfield, C., Britton, J. and van der Erve, L. (2017), 'Higher education finance reform: raising the repayment threshold to $£ 25,000$ and freezing the fee cap at $£ 9,250$ ', Briefing Note no. BN217, Institute for Fiscal Studies (https://www.ifs.org.uk/publications/9964).

Belfield, C., Crawford, C. and Sibieta, L. (2017), Long-Run Comparisons of Spending per Pupil across Different Stages of Education, Report no. R126, Institute for Fiscal Studies (https://www.ifs.org.uk/publications/8937).

Belfield, C. and Sibieta, L. (2016), Long-Run Trends in School Spending in England, Report no. R115, Institute for Fiscal Studies (https://www.ifs.org.uk/publications/8236).

Blanden, J., Del Bono, E., Hansen, K. and Rabe, B. (2017), 'The impact of free early childhood education and care on educational achievement: a discontinuity approach investigating both quantity and quality of provision', University of Surrey, Discussion Paper in Economics no. DP06/17 (https://repec.som.surrey.ac.uk/2017/DP06-17.pdf).

Blanden, J., Del Bono, E., McNally, S. and Rabe, B. (2016), 'Universal pre-school education: the case of public funding with private provision', Economic Journal, vol. 126, pp. 682-723 (https://doi.org/10.1111/ecoj.12374).

Blanden, J., Hansen, K. and McNally, S. (2017), 'Quality in early years settings and children's school achievement', Centre for Economic Performance (CEP), Discussion Paper no. 1468 (http://cep.Ise.ac.uk/pubs/download/dp1468.pdf).

Brewer, M., Cattan, S. and Crawford, C. (2014), 'State support for early childhood education and care in England', in C. Emmerson, P. Johnson and H. Miller (eds), The IFS Green Budget: February 2014, Institute for Fiscal Studies

(https://www.ifs.org.uk/budgets/gb2014/gb2014_ch8.pdf). 
Brewer, M., Cattan, S., Crawford, C. and Rabe, B. (2016), 'Does more free childcare help parents work more?', Institute for Fiscal Studies (IFS), Working Paper no. W16/22 (https://www.ifs.org.uk/publications/8728).

Chowdry, H. and Sibieta, L. (2011), 'Trends in education and schools spending', Briefing Note no. 121, Institute for Fiscal Studies (https://www.ifs.org.uk/publications/5732).

Cunha, F., Heckman, J. J. and Schennach, S. M. (2010), 'Estimating the technology of cognitive and noncognitive skill formation', Econometrica, vol. 78, pp. 883-931

(https://doi.org/10.3982/ECTA6551).

Department for Business, Innovation and Skills (2016), Higher Education: Success as a Knowledge Economy (https://www.gov.uk/government/publications/higher-educationsuccess-as-a-knowledge-economy-white-paper).

Department for Children, Schools and Families (2008), Departmental Report 2008 (https://www.gov.uk/government/publications/department-for-children-schools-andfamilies-departmental-report-2008).

Department for Education (2017a), 'Graduate outcomes for all subjects by university', SFR18/2017 (https://www.gov.uk/government/statistics/graduate-outcomes-for-allsubjects-by-university).

Department for Education (2017b), 'Further education outcome-based success measures: 2014 to 2015', SFR52/2017 (https://www.gov.uk/government/statistics/further-educationoutcome-based-success-measures-2014-to-2015).

Department for Education (2018a), 'Participation in education, training and employment: 2017' (https://www.gov.uk/government/statistics/participation-in-education-training-andemployment-2017).

Department for Education (2018b), 'Education provision: children under 5 years of age, January 2018' (https://www.gov.uk/government/statistics/education-provision-childrenunder-5-years-of-age-january-2018).

Department for Education (2018c), 'Devolution of adult education functions: the transition year - memorandum of understanding'

(https://www.gov.uk/government/publications/devolution-of-adult-education-functionsthe-transition-year-memorandum-of-understanding).

Department for Education (2018d), Apprenticeship Funding in England from August 2018 (https://www.gov.uk/government/publications/apprenticeship-funding).

Department for Education and Employment (1999), 'Education and training expenditure since 1989-90', Statistical Bulletin 10/99 (http://dera.ioe.ac.uk/13586/).

Education and Skills Funding Agency (2018), Schools Block Funding Formulae 2018-19 (https://assets.publishing.service.gov.uk/government/uploads/system/uploads/attachme nt_data/file/726783/Proforma_publication_18-19_FINAL_FOR_PUBLICATION.pdf). 
Foster, D. (2018), 'Adult further education funding in England since 2010', House of Commons Library Briefing Paper no. 7708

(https://researchbriefings.parliament.uk/ResearchBriefing/Summary/CBP-7708).

Green, F., Anders, J., Henderson, M. and Henseke, G. (2017), Who Chooses Private Schooling in Britain and Why?, Centre for Learning and Life Chances in Knowledge Economies and Societies, Research Paper no. 62

(https://www.llakes.ac.uk/sites/default/files/Green\%2C\%20Anders\%2C\%20Henderson\%20 $\% 26 \% 20$ Henseke.pdf).

Harding, C. and Cottell, J. (2018), Childcare Survey 2018, Family and Childcare Trust (https://www.familyandchildcaretrust.org/childcare-survey-2018).

Higher Education Statistics Agency (2018), 'Higher education student statistics: UK, 2016/17 - student numbers and characteristics' (https://www.hesa.ac.uk/news/11-012018/sfr247-higher-education-student-statistics/numbers).

House of Lords Economic Affairs Committee (2018), Treating Students Fairly: The Economics of Post-School Education, Second Report of Session 2017-19, HL139 (https://publications.parliament.uk/pa/ld201719//dselect/ldeconaf/139/139.pdf).

Hupkau, C., McNally, S., Ruiz-Valenzuela, J. and Ventura, G. (2017), 'Post-compulsory education in England: choices and implications', National Institute Economic Review, no. 240, pp. R42-57 (https://doi.org/10.1177/002795011724000113).

Independent Panel on Technical Education (2016), Report of the Independent Panel on Technical Education

(https://assets.publishing.service.gov.uk/government/uploads/system/uploads/attachme nt_data/file/536046/Report_of_the_Independent_Panel_on_Technical_Education.pdf).

Kelly, E., Lee, T., Sibieta, L. and Waters, T. (2018), Public Spending on Children in England: 2000 to 2020, Office of the Children's Commissioner

(https://www.childrenscommissioner.gov.uk/publication/public-spending-on-children/).

Leitch Review of Skills (2006), Prosperity for All in the Global Economy - World Class Skills: Final Report (http://dera.ioe.ac.uk/6322/1/leitch_finalreport051206.pdf).

Mathers, S., Ranns, H., Karemaker, A., Moody, A., Sylva, K., Graham, J. and Siraj-Blatchford, I. (2011), Evaluation of the Graduate Leader Fund: Final Report, Department for Education (https://www.gov.uk/government/publications/evaluation-of-the-graduate-leader-fundfinal-report).

Mathers, S. and Smees, R. (2014), Quality and Inequality: Do Three- and Four-Year-Olds in Deprived Areas Experience Lower Quality Early Years Provision?, Nuffield Foundation (http://www.nuffieldfoundation.org/news/disadvantaged-three-and-four-year-oldslosing-out-good-quality-nursery-provision).

Mathers, S., Sylva, K. and Joshi, H. (2007), Quality of Childcare Settings in the Millennium Cohort Study, Research Report SSU/2007/FR/025, Department for Education and Skills (http://dera.ioe.ac.uk/8088/). 
McNally, S. (2018), 'Apprenticeships in England: what does research tell us?', CVER Briefing Note no. 008, Centre for Vocational Education Research (http://cver.Ise.ac.uk/textonly/cver/pubs/cverbrf008.pdf).

National Audit Office (2016), Entitlement to Free Early Education and Childcare (https://www.nao.org.uk/report/entitlement-to-free-early-education-and-childcare/).

Neighbourhood Nurseries Initiative Research Team (2007), National Evaluation of the Neighbourhood Nurseries Initiative: Integrated Report, Research Report SSU/2007/FR/024, Department for Education and Skills (http://dera.ioe.ac.uk/8089/).

OECD (2018), 'Number of graduates by age' (https://stats.oecd.org/Index.aspx?DataSetCode=EDU_GRAD_AGE\#).

Office for Budget Responsibility (2017), Economic and Fiscal Outlook: November 2017 (http://obr.uk/efo/economic-fiscal-outlook-november-2017/).

Office for Budget Responsibility (2018), Economic and Fiscal Outlook: March 2018 (http://obr.uk/efo/economic-fiscal-outlook-march-2018/).

Paull, G., La Valle, I., Speight, S., Jones, H. and White, C. (2017), Evaluation of Early Implementation of 30 Hours Free Childcare, Research Report, Department for Education (https://www.gov.uk/government/publications/30-hours-free-childcare-earlyimplementation-evaluation).

Powell, A. (2018), 'Apprenticeship statistics: England', House of Commons Library, Briefing Paper no. 06113

(https://researchbriefings.parliament.uk/ResearchBriefing/Summary/SN06113).

Pre-School Learning Alliance (2017), 'Sector views on early years funding and the 30 -hour offer' (https://www.pre-school.org.uk/sites/default/files/30-hour_and_funding_survey__pre-school_learning_alliance.pdf).

Sibieta, L. (2015), 'School spending in England 2010-15', Fiscal Studies, vol. 36, pp. 283-302 (https://doi.org/10.1111/j.1475-5890.2015.12057).

Skills Funding Agency (2017), Adult Education Budget Funding Rates and Formula 2017 to 2018 - Version 1 (https://assets.publishing.service.gov.uk/government/uploads/system/uploads/attachme nt_data/file/585387/Funding_rates_and_formula_2017_to_2018_FINAL.pdf)

Speight, S., Maisey, R., Chanfreau, J., Haywood, S., Lord, C. and Hussey, D. (2015), Study of Early Education and Development: Baseline Survey of Families, Research Report, Department for Education

(http://www.seed.natcen.ac.uk/media/5645/Study_of_early_education_and_development_s urvey_of_families.pdf).

Stewart, K. (2013), 'Labour's record on the under fives: policy, spending and outcomes 1997-2010', LSE, Centre for Analysis of Social Exclusion (CASE), Social Policy in a Cold Climate, Working Paper no. 4 (http://sticerd.Ise.ac.uk/dps/case/spcc/wp04.pdf). 
Stewart, K. and Obolenskaya, P. (2015), 'The coalition's record on the under fives: policy, spending and outcomes 2010-2015', LSE, Centre for Analysis of Social Exclusion (CASE), Social Policy in a Cold Climate, Working Paper no. 12 (http://sticerd.Ise.ac.uk/dps/case/spcc/WP12.pdf).

Student Loans Company (2018), 'Student loans in England: financial year 2017-18', SLC SP 01/2018 (https://www.slc.co.uk/media/10022/slcsp012018.pdf).

Sylva, K., Melhuish, E., Sammons, P., Siraj-Blatchford, I. and Taggart, B. (eds) (2010), Early Childhood Matters: Evidence from the Effective Pre-school and Primary Education Project, London: Routledge.

Treasury Select Committee (2018), Student Loans, Seventh Report of Session 2017-19, HC478 (https://publications.parliament.uk/pa/cm201719/cmselect/cmtreasy/478/478.pdf).

West, A. and Noden, P. (2016), 'Public funding of early years education in England: an historical perspective', LSE, Department of Social Policy, Clare Market Paper no. 21 (http://www.nuffieldfoundation.org/sites/default/files/files/Nuffield\%20Final\%20Report\% 20historical\%2027\%20September\%202016.pdf).

West, A. and Noden, P. (2018), '"Nationalising" and transforming the public funding of early years education (and care) in England 1996-2017', British Journal of Educational Studies (https://doi.org/10.1080/00071005.2018.1478058).

West, A., West, R. and Pennell, H. (1995), 'The financing of school-based education: changing the additional educational needs allowance', Education Economics, vol. 3, pp. 265-75 (https://doi.org/10.1080/09645299500000024).

Wolf, A. (2011), Review of Vocational Education: The Wolf Report, Department for Education and Department for Business, Innovation \& Skills (https://www.gov.uk/government/publications/review-of-vocational-education-the-wolfreport). 